Boris Fehse, Silke Domasch

\title{
6. Themenbereich somatische Gentherapie: Translationale und klinische Forschung ${ }^{1}$
}

\subsection{Grundlagen}

Die Gesamtheit der Erbinformation lebender Organismen (aber auch von Viren) wird als Genom bezeichnet. Beim Menschen (wie auch den anderen Eukaryonten) findet sich der wesentliche Teil der Erbinformation in Form der Chromosomen im Zellkern ${ }^{2}$ („Karyom“) und wird in Form einer doppelsträngigen Desoxyribonukleinsäure (DNA) vererbt. Die DNA speichert die Erbinformationen in der Abfolge beziehungsweise Sequenz ihrer Einzelbausteine, der Nukleotide. Letztere bestehen aus einem Phosphatrest, dem Zucker Desoxyribose und je einer der vier organischen Basen Adenin, Thymin, Guanin und Cytosin. Daher werden die Nukleotide oft vereinfacht über die Anfangsbuchstaben ihrer Basen dargestellt - als A, T, G und C. Ähnlich wie die 25 Buchstaben des Alphabets unterschiedlich kombiniert werden können, um eine Vielzahl von Worten zu bilden, kodiert auch die Abfolge der Nukleotide eine Unmenge unterschiedlicher Informationen. Tatsächlich kann, obwohl nur vier verschiedene Nukleotide existieren, über ihre Sequenz eine praktisch unbegrenzte Menge an Informationen kodiert werden. Schon für einen Abschnitt, der aus nur 500 Bausteinen vier unterschiedlicher Typen (A, T, G, C) besteht, gäbe es $4^{500}$ beziehungsweise 1,07 $\times 10^{301}$ (eine Zahl aus 301 Ziffern) unterschiedliche Möglichkeiten der Anordnung. Das Genom des Menschen besteht aber aus 3 Milliarden Nukleotiden!

Nur ein relativ kleiner Teil des Genoms, die Gene, codiert für Proteine (Eiweiße), die in Form von Strukturbausteinen, Enzymen, Rezeptoren, Botenstoffen oder Transportmolekülen eine entscheidende Rolle für den Aufbau, das Überleben, die Funktion und

1 Eine ausführliche Darstellung zur Entwicklung der „Gentherapie in Deutschland“ enthält der gleichnamige Themenband, der Ende 2011 von der interdisziplinären Arbeitsgruppe Gentechnologiebericht der BBAW herausgegeben wurde (Fehse/Domasch, 2011). In dem vorliegenden Artikel mit Manuskriptstand Oktober 2013 werden daher vor allem Fortschritte der Jahre 2011 bis 2013 dokumentiert. 2 Daneben besitzen bei allen Eukaryonten auch die Mitochondrien, eine Art der Zellorganellen, eigene kleine Genome. 
die Vermehrung der Zellen besitzen. Beim Menschen hat man ca. 23.000 Gene identifiziert. Damit aus einem Gen das korrespondierende Protein gebildet werden kann, muss das Gen in eine für die Proteinmaschinerie lesbare Form umgeschrieben, das heißt transkribiert werden. Dazu wird von der DNA eine sogenannte Boten- oder MessengerRNA (mRNA) abgelesen. Die Sequenz der einzelnen Bausteine (Nukleotide) der mRNA wird dann von den Proteinfabriken der Zelle, den Ribosomen, anhand des sogenannten genetischen Codes in eine Aminosäuresequenz übersetzt (translatiert), welche die primäre Struktur eines Eiweißes bildet.

Der weitaus größte Teil des Genoms (>90 \%) besteht jedoch aus nicht-kodierenden Bereichen. Nicht-kodierende Abschnitte sind nicht nur notwendig, um zum Beispiel eine korrekte Replikation (Kopierung) der Chromosomen im Zuge der Zellteilung zu gewährleisten und dabei die Integrität der kodierenden Bereiche zu schützen. Sie enthalten auch eine Reihe regulatorischer Abschnitte, die unter anderem die Expression einzelner Gene (Promotoren, Enhancer) oder ganzer Genomabschnitte (Locus Control Regions) kontrollieren. Auch finden sich in den nicht-kodierenden Regionen Bereiche, die für verschiedene regulatorische RNAs kodieren. Diese RNAs werden selbst nicht in Proteine umgeschrieben, können aber intrazelluläre Lebensvorgänge auf den unterschiedlichsten Ebenen steuern. Schließlich bestehen auch die meisten proteinkodierenden Gene aus kodierenden (Exone) und nicht-kodierenden (Introne) Bereichen, wobei letztere ebenfalls oft regulatorische Abschnitte enthalten.

Für die meisten Gene ist eine präzise Regulation ihrer Expression essenziell - sowohl in Bezug auf die Ebene der Einzelzelle, als auch was den Organismus betrifft. Dies lässt sich schon daran illustrieren, dass bei mehrzelligen Organismen wie dem Menschen die unterschiedlichsten Gewebe auf der Basis völlig identischer Erbinformationen gebildet werden, da ja alle Zellen des Körpers von einer einzigen Zelle, der befruchteten Eizelle, abstammen. Um die genaue Steuerung zu gewährleisten, existiert eine Vielzahl von Regulationsmechanismen sowohl auf der Ebene des Ablesens der einzelnen Gene (Transkription: Umschreiben in die mRNA, siehe oben), als auch für die nachfolgenden Schritte (post-transkriptionell). Die post-transkriptionelle Steuerung kann zum Beispiel bei der Stabilität der mRNA ansetzen, dem Zusammenfügen der Exone (,Spleißen“), der Effizienz der Translation in das entsprechende Protein oder auch der Proteinstabilität.

Fehler in der Erbsubstanz werden als Mutationen bezeichnet. Wie die obigen Darstellungen nahelegen, können Mutationen sehr unterschiedliche Ergebnisse hervorrufen. Liegt eine Mutation in dem kodierenden Bereich eines Gens vor, das heißt, in jenem Abschnitt, von dem das korrespondierende Protein abgelesen wird, so kann es zur Expression dysfunktionaler Proteine kommen. Oft können solche Proteine ihre Aufgabe in der Zelle gar nichtoder nur noch eingeschränkt erfüllen. Manchmal entstehen aber 
auch hyperaktive Varianten, die ihre Funktion zwar erfüllen, sich dabei aber nicht mehr kontrollieren lassen. Analog können auch Fehler in regulatorischen Regionen unterschiedliche Folgen zeitigen - von einem Funktions- bis zum Kontrollverlust der zu kontrollierenden Gene.

Mutationen können bereits von den Eltern ererbt worden sein (sog. Keimbahnmutationen). Handelt es sich dabei um Mutationen, die zum Verlust essenzieller Genfunktionen führen, können sie sich in Form sogenannter Erbkrankheiten manifestieren (vgl. Kapitel 4). Die weitaus meisten Mutationen akkumulieren Menschen aber im Laufe ihres Lebens in ihren Körperzellen (somatische Mutationen) infolge von Umwelteinflüssen wie beispielsweise UV-Strahlen oder Zellgifte, aber auch durch Fehler der Replikationsmaschinerie bei der Zellteilung. In der Regel haben solche Mutationen keine schwerwiegenden Folgen. Stellen die Mutationen jedoch eine Gefahr für die Zelle beziehungsweise den Organismus dar, werden sie meist von zellulären Kontrollmechanismen oder dem Immunsystem erkannt, sodass die gefährdete Zelle beseitigt wird. Funktionieren diese Überwachungssysteme nicht, können Mutationen zu einem unkontrollierten Zellwachstum und damit zu Krebs führen. Daher wird Krebs auch als erworbene genetische Krankheit bezeichnet.

Verkompliziert wird die Betrachtung genetischer Defekte dadurch, dass Eukaryonten nicht nur über ihr eigenes Genom verfügen, sondern auch noch autonome Minigenome mit sich herumtragen. Diese befinden sich in den Mitochondrien, das sind Zellorganellen, die als Kraftwerke der Zellen dienen. Auch Mitochondrien können Fehler in ihrem Erbgut enthalten, was wiederum zu Erbkrankheiten führen kann. Eine Besonderheit hier ist, dass Mitochondrien nur über die mütterliche Linie vererbt werden.

\subsection{Einführung in die Gentherapie}

Nachdem Gregor Mendel im 19. Jahrhundert die Grundregeln der Vererbung entdeckt hat, dauerte es noch mehrere Jahrzehnte, bis die Desoxyribonukleinsäure (DNA) als Träger der genetischen Information identifiziert wurde. Die Aufdeckung der DNA-Struktur sowie des genetischen Codes ab Mitte des 20. Jahrhunderts wie auch die Beschreibung der ersten DNA-aufbauenden Enzyme eröffneten die Möglichkeit, die Primärsequenzen von Genen und abgeleiteten Proteinen zu identifizieren. Diese Entwicklung mündete in die Einführung der Technologie der rekombinanten DNA Anfang der 70er Jahre des 20. Jahrhunderts, welche es erlaubt, Erbsubstanz nicht nur zu vermehren, sondern auch zu modifizieren.

Bereits Mitte der 1960er Jahre, als sich die reale Möglichkeit der gezielten Veränderung des Erbguts immer stärker abzeichnete, machten die beiden Genetiker und No- 
belpreisträger Joshua Lederberg und Edward Tatum erstmals die Idee der Gentherapie öffentlich (Tatum 1966). ${ }^{3}$ Die dort entwickelte Idee der Gentherapie lässt sich sehr einfach zusammenfassen: Wenn Krankheiten durch Defekte in Genen ausgelöst werden können, dann sollten sich diese Krankheiten auch durch eine Reparatur der defekten Gene therapieren lassen. Nur wenige Jahre später begann eine ausführliche Diskussion nicht nur des Potenzials, sondern auch der ethischen Aspekte der Gentherapie (Freese, 1972; Friedmann/Roblin, 1972; Anderson, 1972, Anderson/Fletcher 1980). ${ }^{4}$ Die Notwendigkeit solcher Diskussionen, aber auch klarer gesetzlicher Regelungen, wurde schon bald durch erste, aus heutiger Sicht teilweise recht abenteuerliche praktische Gentherapieversuche illustriert. Schließlich kam es weltweit zur Etablierung nationaler Regulierungsbehörden sowohl allgemein für die Anwendung gentechnischer Verfahren als auch speziell für gentherapeutische Studien beziehungsweise Produkte (vgl. u. a. Fuchs, 2011:194ff oder Fateh-Moghadam, 2011). Weitgehender internationaler Konsens besteht derzeit unter anderem darüber, dass genetische Korrekturen oder Modifikationen nur an Körperzellen (= somatische Gentherapie), nicht aber an Zellen der Keimbahn durchgeführt werden dürfen. ${ }^{5}$ Auch das sogenannte genetische Enhancement, das vor allem im Zusammenhang mit „Gendoping“ in der öffentlichen Diskussion präsent ist, stößt auf breite Ablehnung sowohl von regulatorischer als auch von Seite der im Feld tätigen Wissenschaftlerinnen und Wissenschaftler.

Die erste offizielle Gentherapiestudie begann am 22. Mai 1989 am National Institute of Health der USA (NIH), wobei es sich eigentlich um eine Genmarkierungs- und nicht um eine Gentherapie-Studie handelte (Rosenberg et al., 1990). ${ }^{6}$ Am 14. September 1990 wurde die erste im engeren Sinne gentherapeutische Studie initiiert: Ein vierjähriges

3 Durch Nachdruck in dem Open Access Journal „Cellular Therapy and Transplantation“ wurde Tatums wegweisender Aufsatz kürzlich einem breiten Publikum zugänglich gemacht. Auch wenn aus heutiger Sicht manche seiner Ideen anachronistisch erscheinen, so lohnt es sich in jedem Fall, diesen visionären Artikel zu lesen: www.ctt-journal.com/1-4-en-tatum-1966.html [11.11.2013].

4 Eine ausführlichere Darstellung der Geschichte der Gentherapie findet sich in Friedmann (1992). Vgl. hier auch Fehse et al., 2011:44 ff.

5 In Deutschland sind genetische Manipulationen der Keimbahn durch das Embryonenschutzgesetz verboten.

6 Genmarkierungsstudien verfolgen diagnostische Zielsetzungen. Die Subsumierung aller Studien, die auf der genetischen Modifikation von Zellen beruhen, unter dem Begriff Gentherapie hatte sowohl Sicherheits- (Patienten, behandelndes Personal, Allgemeinheit) als auch praktische Gründe (Zulassungskriterien, präklinische Toxikologieuntersuchungen). Dieser weit gefassten Definition der Gentherapie folgt man im Wesentlichen bis heute, auch wenn spezielle Formen genetischer Manipulationen (wie z. B. das Einbringen kurzer DNA- oder RNA-Moleküle, aber auch die genetische Vakzinierung) aus Gründen der Praktikabilität in vielen Ländern inzwischen nicht mehr als Gentherapie betrachtet werden. 
Mädchen, das unter einer autosomal rezessiven ${ }^{7}$ genetisch bedingten Krankheit, dem schweren Immunmangelsyndrom ADA-SCID (Severe Combined Immune Deficiency) litt, wurde mit autologen ${ }^{8}$, genkorrigierten T-Lymphozyten behandelt (Blaese et al., 1995).

Schon diese erste therapeutische Studie folgte nur scheinbar der ursprünglichen Idee der Gentherapie, welche die Korrektur defekter Gene zum Vorsatz hatte. Tatsächlich erwies sich das hehre Ziel einer Genreparatur - im Sinne einer Genchirurgie (,genetic surgery“) - als mit den seinerzeit existierenden Techniken praktisch nicht umsetzbar. Stattdessen wurde ein Trick angewandt: $\mathrm{Zu}$ den beiden defekten Kopien des Gens für die Adenosindesaminase wurde in die Zellen des Mädchens eine zusätzliche, intakte Kopie eingebracht. ${ }^{9}$ Wenn auch der therapeutische Erfolg aus einer Reihe von Gründen zunächst limitiert war, so hat dieses Herangehen doch im Prinzip funktioniert. T-Lymphozyten mit intakter ADA-Funktion wurden bei mehreren behandelten Patientinnen auch nach mehr als zehn Jahren noch nachgewiesen (Muul et al., 2003).

Der neue Ansatz, weg von der Reparatur hin zur Addition, hatte eine Reihe ganz grundlegender Konsequenzen. Die ursprüngliche - und heute zumindest vorläufig ad acta gelegte - Idee der Gentherapie fokussierte sich auf die Zielstellung, den Normalzustand eines Genes durch eine Genkorrektur wiederherzustellen. In solch einem Fall würde sich das reparierte Gen weiterhin unter der Kontrolle seiner natürlichen Regulatorelemente befinden. Folglich waren im Optimalfall keine Nebenwirkungen zu erwarten. Dagegen führt das Einbringen einer neuen Genkopie zu einer Reihe offensichtlicher Probleme, die es zu lösen galt:

- Wo wird das neue Gen in der Zelle „untergebracht"?

- Wie wird eine langfristige und idealerweise regulierte Genexpression (auch im Falle einer Differenzierung der Zellen) garantiert?

- Wie wird im Falle einer Zellteilung die Weitergabe des Gens an die beiden Tochterzellen gesichert?

7 Autosomal bedeutet, dass das krankheitsverursachende Gen auf einem der 44 Autosomen (= nicht-Geschlechtschromosomen) liegt; rezessiv heißt, dass sich die betreffende Mutation einer parallel vorhandenen funktionellen Variante des Gens unterordnet, d. h. nur wirksam wird, wenn beide Allele mutiert sind.

8 Autologe Zellen sind eigene, das heißt von den Patienten selbst gewonnene Zellen.

9 Obwohl es sich also um eine Genaddition und nicht wie ursprünglich geplant um eine Reparatur oder einen Ersatz handelte, wird für diese Therapieform oft weiter von „replacement“, also Genersatz gesprochen. 
Mit der Entwicklung von Gentransfervektoren eröffnete sich die Möglichkeit, auf einen Schlag gleich alle genannten Probleme zu adressieren. Die auch Gentaxis genannten Vektoren dienen nicht nur dazu, Gene effizient in unterschiedliche Kompartimente der Zelle zu lotsen, sie übernehmen en passant auch die Steuerung der Genexpression und können bei Bedarf dafür sorgen, dass die eingebrachten Gene an die Tochterzellen weitervererbt werden. Die meisten in der Gentherapie benutzten Vektoren sind von Viren abgeleitet. So macht man sich die über Millionen Jahre der Evolution vervollkommneten Fähigkeiten von Viren zunutze, die eigene Erbsubstanz sozusagen wie ein U-Boot in die Zellen des Wirtsorganismus schleusen. Um die Biosicherheit solcher viralen Vektoren zu gewährleisten, wurden diese in zunehmendem Maße "entkernt", das heißt, dass heutige Vektoren nur noch wenige, für den Gentransfer unabdingbare Elemente mit den Ursprungsviren gemein haben.

Auch wenn die Evolution effizienter Gentransfervektoren einen wichtigen Schritt auf dem Weg zu einer wirksamen Gentherapie darstellte, gibt es unter den heute verfügbaren Vektoren keine „Alleskönner“. Daher werden für verschiedene Zielsetzungen unterschiedliche Vektoren benutzt, jeder mit spezifischen Vor- und Nachteilen (siehe unten). Gegenüber der oben beschriebenen idealen Gentherapie fallen vor allem zwei Nachteile von Vektoren ins Auge: Zum einen ist das der Verlust der natürlichen Kontrollelemente, welcher insbesondere für Gene relevant ist, die einer sehr strengen Regulation unterliegen. Letztere lässt sich in Vektoren praktisch nicht nachstellen, sodass die entsprechenden Gene oft für eine additive Gentherapie nicht infrage kommen. Mit zunehmender Anwendung der Gentherapie wurde auch der zweite Nachteil klinisch immer relevanter: Die Verwendung von Vektoren für den Gentransfer ist mit verschiedenen, teilweise vektorspezifischen und manchmal sehr schweren Nebenwirkungen verbunden. Da es zur Verwendung von Gentransfervektoren für die meisten therapeutischen Zielsetzungen bisher keine Alternative gibt, muss zum gegenwärtigen Zeitpunkt insbesondere bei schweren Erkrankungen ohne Behandlungsalternative ein definitives Risiko von Nebenwirkungen in Kauf genommen werden.

Zugleich eröffnete der Paradigmenwechsel hin zu den Gentransfervektoren völlig neue Perspektiven für die Gentherapie. Während diese ursprünglich nur auf die Behandlung vererbter Krankheiten durch Genersatz abzielte, können über die Gentransfervektoren auch völlig neue Gene in Zielzellen eingebracht werden. Das heißt, Gentherapie kann viel mehr, als defekte Gene zu ersetzen und Erbkrankheiten zu behandeln. Tatsächlich können praktisch beliebige Zielzellen mithilfe der Vektoren, im Idealfall sehr spezifisch, mit neuen Eigenschaften ausgestattet werden. So kann man beispielsweise Tumorzellen durch das Einbringen sogenannter Suizidgene dazu bringen, sich selbst auszuschalten oder auch durch eingebrachte Stimulationsfaktoren Zellen des 
Immunsystems anzulocken. Umgekehrt kann man auch Immunzellen durch genetische Modifikationen gegen Tumorzellen „scharf machen“. Oder Zellen lassen sich mithilfe antiviraler Gene vor tödlichen Viren wie HIV schützen. Schließlich können auch genetische Elemente in Zellen geschleust werden, die dort aktive Gene gezielt unterdrücken. Somit rückte eine Vielzahl anderer Krankheiten, vor allem erworbene genetische Erkrankungen wie Krebs, in den Fokus der Gentherapie.

Zusammenfassend lässt sich sagen, dass sich auf der Basis der vektorbasierten Herangehensweise eine sehr lange Liste möglicher Anwendungen der Gentherapie aufstellen lässt. Dies war einer der Gründe für die Euphorie, mit der sich die neue Technologie Anfang der 1990er Jahre aufmachte, die moderne Medizin zu revolutionieren. Zugleich lag eine von mehreren Ursachen dafür, dass sich die initialen Heilsversprechen lange Zeit in keiner Weise realisieren ließen, in der unzureichenden Entwicklung effizienter und zugleich sicherer Gentransfertechnologien. ${ }^{10}$ Umgekehrt lassen sich viele Erfolge der jüngsten Zeit nicht zuletzt auf verbesserte Technologien zurückführen. Daher ist es nicht verwunderlich, dass die Vektorentwicklung auch heute einen Schlüsselbereich der präklinischen und translationalen Forschung im Feld der Gentherapie darstellt; auch in Deutschland widmen sich viele der im Feld aktiven Wissenschaftlerinnen und Wissenschaftler seit Jahren dieser Thematik.

\subsection{Vektorologie: Effizienz, Sicherheit und Spezifität von Gentransfervektoren}

Wie bereits dargelegt werden Vektoren dazu benutzt, genetische Informationen (zumeist die kodierenden Bereiche von Genen) möglichst effizient in die jeweilige Zielzelle einzuschleusen. Zugleich bringt der Vektor Kontrollelemente in die Zelle, welche die Expression der/s Transgene/s regulieren. Solche Kontrollelemente können viralen aber auch zellulären Ursprungs sein und werden heute in der Regel im Einklang mit der gewünschten Expressionshöhe in der Zielzelle ausgewählt.

Um einen effizienten Gentransfer in Zellen zu gewährleisten, kann man sich einer Reihe unterschiedlicher Methoden bedienen, die sich einem von zwei grundlegenden Verfahren zuordnen lassen: dem viralen (= Transduktion) und dem nicht-viralen bzw. physikochemischen Gentransfer (= Transfektion). In der klinischen Gentherapie werden virale Vektoren deutlich bevorzugt (siehe Kapitel 6.5.2, GT-09). ${ }^{11}$

10 Einer der Pioniere der Gentherapie, Inder Verma, fasste das 1999 wie folgt zusammen: „There are only three problems in gene therapy: delivery, delivery, and delivery“.

11 Vgl. hier auch Fehse et al., 2011:57ff. 


\subsubsection{Virale Vektoren}

Das Grundprinzip der Nutzung von Viren als Vektoren wurde oben bereits kurz eingeführt: Vom Ursprungsvirus werden nur jene genetischen Elemente beibehalten, die für die Verpackung des Genoms in die Viruspartikel (Virionen) sowie die spätere Funktionalität der Virionen unabdingbar sind. Diese im Vektor zwingend vorhandenen cis-aktiven Elemente umfassen beispielsweise bei retroviralen Vektoren das sogenannte Verpackungssignal $\psi$ und die Wiederholungssequenzen an den beiden Enden des viralen Genoms (long terminal repeats). Dagegen können die für den Zusammenbau der Partikel benötigten viralen Proteine durch eine sogenannte Verpackungszelle (in trans) zur Verfügung gestellt werden. Die meisten gebräuchlichen Vektoren enthalten in ihrem Genom also keine Gene mehr, welche für virale Proteine kodieren, sondern nur noch passive virale Elemente zusammen mit den therapeutischen beziehungsweise zu erforschenden Transgenen.

Von Viren abgeleitete Vektoren sind deshalb so effizient, weil sie sich eine Reihe attraktiver Eigenschaften von Viren zunutze machen:

- Viren sind Meister in der Miniaturisierung, optimalen Ausnutzung und Verpackung von genetischer Information. ${ }^{12}$

- Viren haben effiziente Mechanismen entwickelt, um ihr eigenes Genom in Zellen einzuschleusen und dort vor der Eliminierung durch zelluläre Abwehrmechanismen zu schützen.

- Zugleich benötigen Viren nach ihrem Eintritt eine intakte Zelle für ihre eigene Vermehrung. Daraus folgt, dass sie kein „Interesse“ daran haben, die Zelle im Zuge der initialen Infektion zu schädigen. ${ }^{13}$

- Für unterschiedliche Zielsetzungen steht eine große Vielfalt von Viren mit spezifischen Eigenschaften zur Verfügung (integrierende vs. nicht-integrierende, DNA-

12 Viren können auch als biologische Nanopartikel (Durchmesser $\sim 20-200 \mathrm{~nm}$ ) betrachtet werden.

13 Hat die Zelle ,ihre Schuldigkeit getan“, also das Virus vermehrt, ist sie dagegen aus Sicht des Virus verzichtbar und kann zerstört werden. Oft wird dies auch durch eigene Immunzellen des Wirts erledigt. Bei der Benutzung viraler Vektoren ist eine Vermehrung in der Regel nicht erwünscht, sodass es auch nicht zur Zellschädigung kommt. Auch wenn die meisten Vektoren nicht für virale Proteine kodieren, ist jedoch eine Aktivierung des Immunsystems nicht auszuschließen und muss in Betracht gezogen werden. 
und RNA-Viren, enge Zellspezifität (Tropismus) ${ }^{14}$ vs. breites Zielzellspektrum, großes vs. kleines Genom etc.).

- Naturgemäß lassen sich die meisten Viren sehr effizient im Reagenzglas vermehren, was für die praktische Anwendung, das heißt die Vektorherstellung unabdingbar ist.

Zugleich weisen virale Vektoren auch einige Limitationen auf, die sich aus ihrer viralen Herkunft begründen: Erstens erlauben die kleinen Genome der gebräuchlichsten Viren zumeist nur die Verpackung der kodierenden Genbereiche. Manche viralen Genome sind so klein, dass selbst die kodierenden Bereiche größerer Gene nicht mehr verpackt werden können. Auch für Promotoren mit großen regulatorischen Bereichen ist in vielen viralen Vektoren kaum Platz. Daher wird gern auf kompakte virale Vektoren zurückgegriffen, die oft sehr stark im Vergleich zu zellulären Promotoren sind. Zweitens lösen viele virale Vektoren bei in vivo Anwendungen eine zum Teil sehr starke Immunantwort aus, besonders wenn zuvor schon Kontakt mit dem Ursprungsvirus bestand. Dies kann nicht nur zu einem schnellen Verlust der therapeutischen Wirksamkeit führen; überschießende Immunreaktionen können auch schwere Nebenwirkungen verursachen. Drittens übernehmen virale Vektoren grundsätzlich den Tropismus ihrer Ausgangsviren beziehungsweise benutzen deren Hüllproteine. Dies bringt bestimmte Einschränkungen mit sich: Vektoren, die unterschiedlichste Zelltypen in vitro sehr effizient transduzieren, sind in der Grundlagenforschung sehr populär, für klinische in vivo Applikationen aber weniger gut geeignet. Außerdem birgt viertens die Verwendung von Vektoren, die von humanpathogenen Viren abgeleitet sind, zumindest ein theoretisches Biogefährdungspotenzial. Aufgrund des beschriebenen Aufbaus moderner Vektoren kann die Entstehung replikationskompetenter, das heißt vermehrungsfähiger Viren aus klinisch verwendeten Vektoren jedoch faktisch ausgeschlossen werden. ${ }^{15}$ Und fünftens weisen unterschiedliche Vektoren neben den genannten, meist in unterschiedlichem Maße für alle oder viele virale Vektoren zutreffenden Einschränkungen, zudem auch spezifische Limitationen auf - beispielsweise hinsichtlich der Stabilität der Genexpression (z. B. integrierende vs. nicht-integrierende Vektoren) oder der genetischen Identität. ${ }^{16}$ Die derzeit in der klinischen Gentherapie wichtigsten

14 Der Tropismus von Viren wird in der Regel über Hüllproteine definiert, die mit spezifischen Rezeptoren auf der Zellmembran interagieren. Inzwischen ist es für viele Viren gelungen, den Tropismus durch geeignete Modifikationen der Hüllproteine gezielt zu modifizieren.

15 Zugleich muss man aber davon ausgehen, dass zum Beispiel gegen die Anwendung von Vektoren, die vom Humanen Immundefizienz-Virus (HIV) abgeleitet wurden, bei einigen Patientinnen und Patienten eine psychologische Hemmschwelle besteht.

16 Manche Viren wie Retroviren weisen eine besonders hohe Mutationsrate auf, was evolutionär von Vorteil, für ein Gentherapieprodukt aber nicht erwünscht ist. 
viralen Vektoren wurden von Adeno-, Retro-, Vaccinia-, Pox-, Adeno-assoziierten sowie Herpes simplex-Viren abgeleitet.

Genutzte Vektoren zu klinischen Studien zur Gentherapie

(Juli 2013, im Einzelnen siehe Kapitel 6.5.2, GT-09)

$\begin{array}{lr}\text { Adenoviren } & 23,5 \% \\ \text { Retroviren } & 19,1 \% \\ \text { Vaccinaviren } & 7,8 \% \\ \text { Poxviren } & 4,8 \% \\ \text { Adeno-assoziierte Viren } & 5,2 \% \\ \text { Herpes simplex Viren } & 3,1 \%\end{array}$

Die (Weiter-)Entwicklung der verschiedenen Vektoren erfolgt im Einklang mit den gewünschten therapeutischen Anwendungen. Prinzipiell können letztere eine langfristige/dauerhafte Expression des therapeutischen Gens erfordern oder aber eine zeitweise/transiente. Für beide Zielstellungen stehen eine Reihe unterschiedlicher Vektoroptionen zur Verfügung (vgl. Übersicht in Fehse et al., 2011).

Die Integration eines Vektors in das Zielgenom garantiert seine Weitergabe an die Tochterzellen im Zuge der Zellteilung. Die bekanntesten obligatorisch integrierenden Vektoren wurden von Einzel(+)-Strang RNA-Viren, den Retroviren, abgeleitet. Die Integration erfolgt enzymvermittelt, sodass es an der Insertionsstelle nicht zu Schädigungen der chromosomalen DNA kommt. ${ }^{17}$ Tatsächlich konnte in einer Reihe von klinischen Studien gezeigt werden, dass retrovirale Vektoren eine Expression therapeutischer Gene über viele - bei einigen Patientinnen und Patienten inzwischen über 20 - Jahre ermöglichen.

Schon die allerersten Gentherapiestudien (siehe oben) benutzten retrovirale Vektoren, die auf sogenannten $\gamma$-Retroviren basierten. Noch immer werden $\gamma$-retrovirale Vektoren in mehr als einem Fünftel der Gentherapiestudien verwendet, jedoch werden sie in den letzten Jahren in zunehmendem Maße durch andere retrovirale, sogenannte lentivirale Vektoren verdrängt, die höhere Transduktionseffizienz mit einem wahrscheinlich geringeren Risiko unerwünschter Nebenwirkungen verbinden. Aber auch weitere Vertreter der Familie der Retroviren ( $\alpha$-Retroviren, Foamyviren) haben sich, nicht zuletzt auf Basis grundlegender Forschungen in Deutschland, als aussichtsreiche Kandidaten für die Ableitung von Vektoren erwiesen. Insgesamt kommen viele, auch

17 Natürlich stellt die Insertion per se eine Schädigung (Mutagenese) dar. An der Insertionsstelle kommt es zudem zur Duplikation von zwei Nukleotiden. Darüber hinaus bleibt die chromosomale DNA aber stabil. 
sehr frühe Arbeiten zur Entwicklung retroviraler Vektoren für klinische und präklinische Anwendungen aus Deutschland. ${ }^{18}$ Dieser Schwerpunkt wurde auch in den letzten Jahren von mehreren Gruppen weiterentwickelt. ${ }^{19}$

Durch Nutzung alternativer Hüllproteine ${ }^{20}$ (Pseudotypisierung) kann das Zielzellspektrum retroviraler Vektoren für unterschiedliche Zellen optimiert werden (Mock et al., 2012). Besonders interessant ist das sogenannte Targeting retroviraler Vektoren, das heißt die Generierung von Partikeln, die nur einen bestimmten Zelltyp hochspezifisch transduzieren; hier gab es zuletzt große Fortschritte im präklinischen Bereich. ${ }^{21}$ Alternativ beziehungsweise zusätzlich kann die Spezifität von Vektoren auch durch die Wahl geeigneter genetischer Kontrollelemente (z. B. gewebespezifischer Promotoren, microRNA target-sites) im Vektor selbst gesteuert werden (Frecha et al., 2008). Ein solches transkriptionelles beziehungsweise post-transkriptionelles Targeting ist unabhängig vom verwendeten Vektortyp sowohl für virale als auch nicht-virale Vektoren möglich (Brendel et al., 2012, 2013; Kopp et al., 2013; Haase et al., 2013). Dies ist besonders wichtig, wenn das therapeutische Gen nicht direkt in die Zellen eingebracht werden kann, in denen es exprimiert werden soll, sondern in Vorläuferzellen, in denen die Expression des Gens oder die Aktivität eines starken, zum Beispiel viralen Promotors/ Enhancers potenziell unerwünschte Effekte hervorrufen kann. ${ }^{22}$

18 In Deutschland ist mit der EUFETS GmbH auch eine der wenigen europäischen Firmen beheimatet, die unter GMP-Bedingungen unterschiedliche Arten retroviraler Vektoren für klinische Studien sowohl in Europa als auch den USA herstellt, vgl. www.eufets.com/ [25.10.2013].

19 Im Einzelnen siehe z. B. Weber et al., 2008, 2010; Bodem et al., 2011; Lindemann/Rethwilm, 2011; Müllers et al., 2011; Suerth et al., 2010, 2012; Matthes et al., 2011; Ho et al., 2012; Plochmann et al., 2012; Kaufmann et al., 2013; Hütter et al., 2013; Weber et al., 2013; Jaguva Vasudevan et al., 2013.

20 Dabei können modifizierte wie auch unmodifizierte Hüllproteine anderer Retroviren benutzt werden, aber auch Glykoproteine, die von völlig unverwandten Viren stammen.

21 Prinzipiell kann die Spezifität von Vektoren auf zwei Wegen erhöht werden: durch targeting (= Erhöhung der Spezifität für die Zielzelle, z. B. durch Kopplung mit hochspezifischen Antikörpern) oder durch detargeting (= Verringerung der Bindungswahrscheinlichkeit an andere als die Zielzellen, z. B. an den natürlichen Liganden); vgl. Abel et al., 2011. Insbesondere zu nennen sind die deutschen Arbeiten von Buchholz (Langen) zum Targeting lentiviraler Vektoren mithilfe modifizierter Hüllproteine des Masernvirus, vgl. Funke et al., 2008, 2009; Anliker et al., 2010; Münch et al., 2011; Zhou et al., 2012; Kneissl et al., 2012.

22 Zum Beispiel tritt bei einer erblichen Immunmangelerkrankung, der chronischen Granulomatose, der Gendefekt in sehr kurzlebigen (1-3 Tage) Zellen des Immunsystems, den Granulozyten, auf. Eine wirksame Therapie ist hier nur möglich, wenn das therapeutische Gen (gp91phox) in langlebige Blutstammzellen, aus denen die Granulozyten gebildet werden, eingebracht wird. Eine erste klinische Studie in Deutschland zeigte jedoch, dass es infolge des Transfers des gp91phox in Blutstammzellen zur Leukämieentstehung infolge einer Insertionsmutagenese kommen kann (Ott et al., 2006; Stein et al., 2010). 
Die Integration retroviraler Vektoren in das Zielzellgenom stellt eine entscheidende Voraussetzung für die dauerhafte Expression des eingebrachten therapeutischen Gens auch über viele Zellteilungen hinweg dar. Zugleich stellt jede Insertion eine Veränderung der Integrität des Genoms und somit eine Mutation dar. Zum Beispiel kann eine zufällige Insertion mitten in einem Gen landen und dieses zerstören. Bei jedem Gentransfer ist zudem zu berücksichtigen, dass in dem Vektor zusammen mit dem Transgen auch Kontrollelemente (Promotoren, Enhancer) in das Genom eingebaut werden, welche die Expression nicht nur des eingebrachten, sondern eventuell auch umliegender Gene beeinflussen. Aufgrund der Größe des Genoms und vielfältiger Komplementationsmechanismen bleiben Mutationen infolge von Vektorinsertionen in der Regel ohne Auswirkungen auf die Physiologie der Zelle (sog. stille Mutationen). Sie können aber prinzipiell auch zu einem (z. B. Wachstums-) Nachteil oder Vorteil führen. Lassen sich Änderungen der Zellphysiologie infolge der Vektorintegration nachweisen, wird von einer Insertionsmutagenese gesprochen.

Grundsätzlich erfolgt die Integration von Retroviren weitgehend ungerichtet, wobei unterschiedliche Retroviren gewisse Vorlieben für bestimmte Bereiche des Genoms entwickelt haben (Mitchell et al., 2004); diese Integrationsprofile wurden auch an die von den verschiedenen Viren abgeleiteten Vektoren weitergegeben (ausführlich: Fehse et al., 2011:59 ff.). Aufbauend darauf werden für verschiedene retrovirale Vektoren unterschiedliche Risiken einer Insertionsmutagenese („Genotoxizität“) postuliert. Allerdings zeigte sich auch, dass unabhängig vom Vektortyp der Aufbau des Vektors und insbesondere die Anwesenheit starker (viraler) Promotoren und Enhancer definierend für das Risiko einer Insertionsmutagenese sind (Modlich et al., 2006, 2009). In der Folge konnte durch gezielte Änderungen des Designs der Vektoren eine signifikante Senkung des Risikos einer Insertionsmutagenese, zunächst in präklinischen Modellen, gezeigt werden. Mehrere der neu entwickelten Vektoren befinden sich inzwischen in der klinischen Prüfung (Corrigan-Curay et al., 2012).

Traditionell nehmen deutsche Wissenschaftlerinnen und Wissenschaftler eine führende Rolle bei der Erforschung der Sicherheit retroviraler Vektoren ein. ${ }^{23}$ So ließen sich schwere Nebenwirkungen des retroviralen Gentransfers auf der Basis in Deutschland konzipierter Mausmodelle vorhersagen (Li et al., 2002; Kustikova et al., 2005; Modlich et al., 2005); ein im Labor von Christopher Baum entwickelter Zellkultur-Assay (Modlich et al., 2006, 2009) gilt heute als zulassungsrelevanter Standard zur Testung unterschiedlicher retroviraler Vektoren hinsichtlich ihres genotoxischen Potenzials (vgl. auch Fehse et al., 2011).

23 Siehe hier die Arbeiten von Baum et al., 2011; Maetzig et al., 2011; Newrzela et al., 2011, 2012; Heckl et al., 2012; Cornils et al 2013 oder Heinnich et a1., 2013. 
Überraschenderweise zeigte sich in bisherigen klinischen Studien (siehe unten), dass Nebenwirkungen des retroviralen Gentransfers oft mit Insertionen in definierten Genen assoziiert sind. So wurden in zwei unabhängigen Studien zur Gentherapie des schweren Immunmangelsyndroms SCID-X1 in London und Paris fünf Leukämien infolge einer Insertionsmutagenese beobachtet. Bei vier davon war der Vektor in der Nähe desselben Protoonkogens (Lmo2) inseriert und hatte dieses aktiviert (Hacein-Bey-Abina et al., 2008; Howe et al., 2008). Die Aktivierung eines anderen Protoonkogens (Evi1) durch Insertionsmutagenese führte ebenfalls zur Leukämieentstehung in unabhängigen klinischen Studien (Stein et al., 2010; Avedillo Díez et al., 2011). Bemerkenswerterweise gab es für genau dieses Gen analoge Befunde im Tiermodell (Li et al., 2002; Kustikova et al., 2005; Modlich et al., 2008). Diese Ergebnisse unterstrichen die Bedeutung der Analyse der Gesamtheit der Insertionsstellen („Integrom“) retroviraler Vektoren.

Internationale Pionierarbeit auf diesem Gebiet, insbesondere hinsichtlich der Einführung von Hochdurchsatzanalysen, wurde von der Gruppe um Christof von Kalle geleistet. ${ }^{24}$ Inzwischen gilt das Integrom-Monitoring als wichtiger Bestandteil der Sicherheitsuntersuchungen im Rahmen gentherapeutischer Studien. Analoge Analysen werden zudem auch für andere Vektorsysteme sowohl obligat (z. B. Transposons) als auch für zufällig integrierende (z. B. AAV-) Vektoren durchgeführt (Voigt et al., 2012; Kaeppel et al., 2013). Auch können die entwickelten Hochdurchsatztechniken auf andere Fragestellungen wie beispielsweise die Inzidenz unerwünschter „off-target“-Effekte von Designernukleasen adaptiert werden (Gabriel et al., 2011).

Neben den integrierenden gibt es eine ganze Reihe nicht-integrierender beziehungsweise episomaler viraler Vektoren. Viele dieser Vektoren zeichnen sich durch exzellente Transduktionsraten und eine relativ einfache Herstellung hochtitriger Vektorpräparationen aus, was sie für klinische Anwendungen interessant macht (Ehrhardt et al., 2008). Die meisten episomal (also nicht als Teil des Genoms) vorliegenden Vektoren werden bei Zellteilungen ausgedünnt, da keine gleichmäßige Verteilung auf die Tochterzellen erfolgt. ${ }^{25}$ In diesen Fällen erlauben sie nur eine transiente Transduktion. Allerdings gibt es viele Gewebe im Körper wie zum Beispiel Muskel- oder Leberzellen, die gar keine oder nur eine sehr geringe Teilungsaktivität zeigen. In diesen Geweben können auch nicht-integrierende Vektoren eine langfristige Genexpression vermitteln.

24 Siehe Literatur im Einzelnen: Schmidt et al., 2007; Schwarzwaelder et al., 2007; Gabriel et al., 2009; Stein et al., 2010; Paruzynski et al., 2010; Boztug et al., 2010 und Arens et al., 2012.

25 Es gibt allerdings auch episomale Vektoren (z. B. basierend auf Herpesviren), die sich in der Zelle selbst (autonom) vermehren können und so eine permanente genetische Modifikation erlauben. 
Ein transienter Gentransfer ${ }^{26}$ hat nicht nur Nachteile, sondern bietet sich im Gegenteil für eine ganze Reihe von Zielstellungen an. So kann eine kurzfristige Expression immunstimulatorischer Gene in malignen Zellen ausreichen, um das Immunsystem gegen den Tumor zu aktivieren. Auch im Rahmen anderer gentechnischer Vakzinierungsstrategien zielt man in der Regel nur auf eine transiente Expression der Antigene. In der Krebsgentherapie werden zudem Strategien zur Expression von toxischen oder Suizidgenen in Tumorzellen verfolgt, um die Zellen in den Zelltod zu treiben. Ein permanenter Gentransfer wäre hier oft kontraproduktiv, da er potenziell mit unerwünschten Nebenwirkungen behaftet ist.

Aus Platzgründen sollen hier nur zwei der populärsten nicht-integrierenden viralen Vektoren eingeführt werden, die von Adenoviren (AV) beziehungsweise Adeno-assoziierten Viren (AAV) abgeleitet wurden: ${ }^{27}$ Aus der Vielfalt unterschiedlicher Vektoren heben sich diese vor allem dadurch ab, dass sie die Grundlage für die drei international bisher zugelassenen Gentherapeutika bildeten: AV-Vektoren - Gendicine (SiBiono Gene Tech, China) und H101 (Sunway, China), AAV-Vektor - Glybera (UniQure, Niederlande).

AV- und AAV-Vektoren weisen einige Gemeinsamkeiten aber auch deutliche Unterschiede auf. Von beiden Virusarten wurden schon Mitte der 1990er Jahre Vektoren abgeleitet. Bei den Ausgangsviren handelt es sich jeweils um unbehüllte DNA-Viren, die zunächst beim Menschen gefunden worden waren. Mehrere Unterarten der Adenoviren verursachen beim Menschen verschiedene Krankheiten wie zum Beispiel Erkältungen, AAV gelten dagegen nicht als humanpathogen. Sowohl von AV als auch AAV gibt es eine Reihe unterschiedlicher Serotypen, ${ }^{28}$ die spezifische Eigenschaften aufweisen und sich aufgrund teilweise unterschiedlicher Gewebetropismen für die Transduktion verschiedener Zielgewebe eignen. Adenoviren liegen in der infizierten Zelle episomal vor, wohingegen AAV mit hoher Inzidenz in einer bestimmten Region des Chromosoms 19

26 Anzumerken ist, dass es auch beim transienten Gentransfer zu „zufälligen“ Insertionen in das Zielzellgenom kommen kann, z. B. im Rahmen von Reparaturprozessen des Genoms, wenn auch mit sehr geringer Frequenz (0,1 Promille) (Stephen et al., 2010). Da in der Klinik regelhaft große Vektormengen (z. B. >10 Milliarden Partikel) eingesetzt werden, kann es sich immer noch um viele Tausend Insertionsereignisse handeln. Da die Integration weitgehend ungerichtet erfolgt und nichtenzymatisch vermittelt wird, gilt die Wahrscheinlichkeit genomischer Aberrationen (Schädigungen) als höher als z. B. bei regelhaft integrierenden Retroviren. Tatsächlich wurde eine AAV-Insertionsmutagenese im Mausmodell beobachtet (Donsante et al., 2007). Eine aktuelle Studie für das AAV-basierte Gentherapeutikum Glybera zeigt aber kein auffälliges Mutageneserisiko (Kaeppel et al., 2013).

27 Eine Übersicht über weitere nicht-integrierende Vektoren findet sich in Fehse et al., 2011:63 ff.

28 Viren und auch Bakterien einer Art können oft anhand von Serotypen klassifiziert werden. Ein gegebener Serotyp ist durch die Bindung bestimmter Antikörper an virale Oberflächenantigene charakterisiert. 
integrieren; allerdings gilt das nicht für AAV-Vektoren, da bei ihnen das Gen, welches die Integration vermittelt, entfernt wurde. Die Integration von AAV ist Teil seiner Überlebensstrategie. AAV ist mit circa $20 \mathrm{~nm}$ selbst für ein Virus sehr klein und verfügt nur über ein Minigenom von $4.7 \mathrm{~kb}$ einzelsträngiger DNA mit zwei eigenen Genen. Damit ist es nicht in der Lage, sich selbst zu vermehren (replikationsinkompetent), sondern benötigt die Hilfe anderer, zum Beispiel Adenoviren. Im integrierten Zustand warten AAV sozusagen bis - salopp gesagt - mal wieder ein Zug vorbeikommt, auf welchen sie aufspringen können. Bei Adenoviren handelt es sich dagegen um relativ große Viren (70 bis $90 \mathrm{~nm}$ ) mit einem doppelsträngigen DNA-Genom von ca. 45 kb Länge.

Adenovirale Vektoren sind seit Jahren die populärsten Gentransfervektoren in der somatischen Gentherapie. Diesen Status haben die Vektoren auch nicht eingebüßt, als sie im Jahre 1998 durch den Tod Jesse Gelsingers, eines Probanden in einer Gentherapiestudie in Philadelphia (USA), stark in Misskredit und in den Fokus der öffentlichen Diskussion gerieten. ${ }^{29}$ Die akuten toxischen Nebenwirkungen in jener Studie waren vor allem auf die Immunogenität von Adenoviren zurückzuführen. Diese kann offensichtlich bei einigen der Patientinnen und Patienten, die mit dem verwendeten Serotyp bereits Kontakt hatten, besonders schwere systemische Entzündungsreaktionen - vergleichbar einem anaphylaktischen Schock - auslösen, was bei Gelsinger zu einem akuten Multiorganversagen führte (Raper et al., 2003). Die starke Immunogenität adenoviraler Vektoren stellt ein grundsätzliches Problem für in vivo Anwendungen dar, da wiederholte Vektorapplikationen mit demselben Serotyp praktisch unmöglich sind. Selbst für AAV-Vektoren, die als wesentlich weniger immunogen gelten, wurden starke Immunreaktionen beschrieben (Mingozzi et al., 2007), die beispielsweise den initialen Erfolg einer Gentherapiestudie bei Hämophilie B konterkarierten (Manno et al., 2006). Allerdings kann die Immunogenität von Vektoren für bestimmte Zielstellungen wie die Aktivierung des Immunsystems durch Vakzinierungen gegen Tumoren oder auch pathogene Viren sehr hilfreich sein. Um die potenziellen Risiken dieser Vektoren zu minimieren, wurde eine neue Generation adenoviraler Vektoren entwickelt, bei denen alle viralen Gene entfernt wurden. Dadurch wurde sowohl das Risiko der Entstehung replikationskompetenter Viren als auch die Immunogenität der AV-Vektoren gesenkt. Bei der Entwicklung solcher "gutless"-Vektoren waren mehrere deutsche Forschende maßgeblich beteiligt (Kochanek et al., 1996; Lieber et al., 1996; Kochanek et al., 2001).

Die entkernten Adenovektoren verfügen über eine vergleichsweise sehr große Verpackungskapazität von 40 bis $45 \mathrm{~kb}$ und lassen sich gut produzieren (Jager et al., 2009).

29 Eine ausführliche Darstellung zu weiteren Problemen jener Studie findet sich u. a. bei Domasch/ 
Dies macht sie nicht nur attraktiv für den Transfer großer Gene inklusive regulatorischer Bereiche, sondern auch als eine Art „Flugzeugträger“ für den Transport anderer Vektoren in die Zellen (sog. Hybridvektoren). So können mithilfe solcher chimärer Vektoren (Kaufmann/Nettelbeck, 2012) die ausgezeichneten Gentransfereffizienzen adenoviraler Vektoren mit den Vorzügen anderer, persistierender Vektorsysteme verbunden werden. Gerade bei solchen übergreifenden Fragestellungen hilft den deutschen Wissenschaftlerinnen und Wissenschaftlern ihre ausgezeichnete Vernetzung, um wichtige kooperative Beiträge zu leisten (Hausl et al., 2010; Weber et al., 2013; Voigtlander et al., 2013). ${ }^{30}$

Das sehr kleine Genom von AAV-Vektoren setzt ihrer Anwendbarkeit definierte Grenzen bezüglich der Größe des Transgens und des Promotors. Aufgrund ihres nach heutigem Kenntnisstand sehr guten Sicherheitsprofils sind diese Vektoren trotzdem sehr populär, insbesondere für den Einsatz in nicht-teilungsaktiven Geweben wie Leber, Muskeln oder Netzhaut. Eine Reihe aufsehenerregender Gentherapiestudien der letzten Jahre wurden mit AAV-Vektoren durchgeführt (siehe unten).

Da sowohl AV- als auch AAV-Vektoren keine Lipidmembranhülle besitzen, sind die Vektorpartikel vergleichsweise stabil. Ein besonderer Vorzug besteht darin, dass sich die Kapside in verschiedener Weise modifizieren lassen, wodurch zum einen der Tropismus aber auch die Immunogenität der Vektoren beeinflusst werden kann. Beide Ziele können zum Beispiel über eine chemische Modifizierung adenoviraler Partikel erreicht werden (Prill et al., 2011). Auf der Basis ihrer negativen Ladung können AV-Vektoren auch mit positiv geladenen Polymeren überzogen werden, die sich nicht-kovalent an das Kapsid anlagern. An die Polymere wiederum können chemisch Liganden gekoppelt werden, die spezifisch mit ihren Rezeptoren wechselwirken, wodurch die Transduktion der gewünschten Zielzelle favorisiert wird (Vetter et al., 2013). Liganden zellulärer Rezeptoren können aber auch direkt kovalent an Fiber- oder Hexonproteine gebunden werden, um den Tropismus der AV-Vektoren zu modifizieren (Laakkonen et al., 2012).

Sehr elegant lässt sich der Tropismus bei AAV-Vektoren verändern. Nachdem die für die Bindung an die zellulären Rezeptoren essenziellen Bereiche des Kapsidproteins identifiziert waren, wurde von Hallek gezeigt, dass sich die Spezifität durch den Austausch dieser gegen andere Peptide ändern lässt (Girod et al., 1999). Auch im Weiteren haben deutsche Gruppen auf diesem Gebiet Pionierarbeit geleistet, indem sie zeigten, dass durch den Einbau von sogenannten Peptidbibliotheken in die bindungsrelevanten Bereiche des Kapsids Vektorpartikel mit einer Vielzahl unterschiedlichster Spezifitä-

30 Die Vernetzung wurde in diesem Bereich zuletzt u.a. durch das sehr erfolgreiche DFG-Schwerpunktprogramm SPP1230. Mechanism of Gene Vector Entry and Persistence" gefördert. 
ten generiert werden können (Perabo et al., 2003; Müller et al., 2003). Diese Partikel können dann wiederum auf die Bindung an ein gegebenes Antigen beziehungsweise eine bestimmte Zielzelle selektioniert werden. Über mehrere solcher Selektionszyklen können schließlich die Partikel beziehungsweise Peptide identifiziert werden, die einen effizienten und idealerweise hochspezifischen Gentransfer in das gewünschte Zielgewebe vermitteln. ${ }^{31}$ Zudem konnte gezeigt werden, dass durch die Kapsidmodifikation die Immunogenität der AAV-Partikel sowohl herabgesetzt (um die Effizienz der Applikation im Rahmen einer in vivo Gentherapie zu erhöhen) als auch erhöht werden kann (z. B. für die Nutzung der Partikel als Vakzin) (Bartel et al., 2011; Rybniker et al., 2012). Wie beschrieben kann der Tropismus unterschiedlicher Gentransfervektoren durch gezielte Modifikation der Liganden (Hüll- oder Kapsidproteine) zellulärer Rezeptoren verändert werden. Darüber hinaus besteht die Möglichkeit, in der zu übertragenden Erbsubstanz Kontrollelemente einzubauen, die eine Zell- beziehungsweise Gewebespezifität vermitteln. Am naheliegendsten erscheint hier die Verwendung gewebespezifischer Expressionskassetten (Promotoren, Enhancer). Exemplarisch sei hier die nicht zuletzt von Manuel Grez (Frankfurt am Main) vorangetriebene Entwicklung und Analyse unterschiedlicher Promotoren genannt, die eine effiziente wie auch selektive Expression therapeutischer Gene in myeloiden Zellen des Blutsystems ermöglichen (Moreno-Carranza et al., 2009; Santilli et al., 2011; Brendel et al., 2012; Brendel et al., 2013; Stein et al., 2013). Eine weitere Möglichkeit, die Transgenexpression auf bestimmte Zelltypen zu beschränken beziehungsweise in anderen Zellen zu verhindern, besteht im Einbau von microRNA-Erkennungsstellen in den Vektor (Brown et al., 2006, 2007). Den genannten Möglichkeiten ist gemein, dass sie grundsätzlich gleichermaßen für die Anwendung in viralen als auch nicht-viralen Vektortypen geeignet sind, solange keine Beschränkungen hinsichtlich der Größe der im Vektor verbaubaren Elemente wirksam werden.

Während der Ausschluss der Replikationsfähigkeit bei Gentransfervektoren zumeist ein wichtiges Sicherheitskriterium darstellt, werden in der Onkologie sogenannte konditionell replizierende onkolytische Vektoren immer populärer (Liu et al., 2007). Auch deutsche Teams arbeiten aktiv an der Entwicklung und Anwendung solcher Vektoren. Das Wirkprinzip onkolytischer Viren besteht darin, sich selektiv in Tumorzellen zu vermehren und diese dadurch zu zerstören. Um die notwendige Selektivität zu erreichen, wurden die Viren dabei so verändert, dass sie für den Zelleintritt oder die

31 Dieses Konzept wurde in den letzten Jahren benutzt, um eine ganze Reihe gewebespezifischer AAV-Vektoren von mehreren Gruppen in Deutschland weiterzuentwickeln, vgl. Märsch et al., 2010; Michelfelder et al., 2011; Varadi et al., 2012; Naumer et al., 2012; Uhrig et al., 2012 oder jüngst Münch et al., 2013. 
Vermehrung auf eine bestimmte Eigenschaft der Tumorzellen angewiesen sind. Paradigmatisch hierfür kann man das erste breit verwendete onkolytische Virus ONYX015 betrachten. ${ }^{32}$ Da ONYX015 normalen Zellen nichts anhaben kann, handelt es sich theoretisch um eine ideale, sich selbst-limitierende Waffe gegen Tumoren und deren Metastasen. Leider erfüllten sich die hohen Erwartungen an ONYX015 aber nicht, da das Virus aufgrund seiner Immunogenität sehr schnell vom Immunsystem behandelter Patientinnen und Patienten beseitigt wurde, ehe es alle Tumorzellen zerstören konnte. Aufgrund der trotzdem in klinischen Studien beobachteten Wirksamkeit wurde ein nahezu identisches Virus unter dem Namen Oncorine als weltweit zweites kommerzielles Gentherapieprodukt durch die Firma Shanghai Sunway Biotech in China lizenziert. ${ }^{33}$

Inzwischen wurde eine Reihe sehr unterschiedlicher Viren genetisch so umgebaut, dass sie als onkolytische Viren benutzt werden können (vgl. zur Übersicht: Seymour, 2011; Russell et al., 2012). Das Feld entwickelt sich rasant: ${ }^{34}$ Viele onkolytische Viren werden derzeit bereits in teilweise großen multizentrischen klinischen Studien getestet (Eager/Nemunaitis, 2011; Patel/Kratzke, 2013); die bisher bekannt gewordenen Daten großer Studien sind vielversprechend. ${ }^{35}$ Nicht zuletzt der Einstieg großer Pharmaunternehmen wie der weltweit wichtigsten Biotechnologie-Firma Amgen in das Feld unterstreicht das Potenzial, das onkolytischen Viren in der Onkologie zugebilligt wird (Kirn et al., 2011). Auch viele deutsche Wissenschaftlerinnen und Wissenschaftler arbeiten weiterhin sehr erfolgreich an unterschiedlichen Plattformen für die onkolytische Virotherapie. ${ }^{36}$

32 Diesem Adenovirus fehlt ein essenzielles Gen (E1B55K), dessen Genprodukt an das Tumorsuppressormolekül p53 bindet. Durch die Inaktivierung des p53 kann sich das Virus in der infizierten Zelle vermehren, ohne dass in der infizierten Zelle der induzierte Zelltod (Apoptose) ausgelöst wird. Fehlt dem Virus E1B55K, kann es sich in normalen Zellen nicht mehr vermehren, aber immer noch in Zellen, die kein funktionelles p53 besitzen; gerade der Verlust von p53 ist aber charakteristisch für Tumorzellen. Tatsächlich wurde für ONYX015 gezeigt, dass es sich nur in p53-negativen Zellen (also konditionell) replizieren kann und diese dadurch zerstört (Bischoff et al., 1996).

33 www.sunwaybio.com.cn/en/product.html [11.11.2013].

34 Dies lässt sich z. B. dadurch illustrieren, dass seit Ende 2010 mehr als 100 Übersichtsarbeiten zum Thema onkolytische Viren erschienen sind (17.07.2013).

35 www.jennerex.com, www.amgen.com/media/media_pr_detail.jsp?releaseID=1798143 [25.11.2013] 36 Siehe im Einzelnen: Mühlebach et al., 2010; Rommelaere et al., 2010; Kiprianova et al., 2011; Quirin et al., 2011; Weibel et al., 2011; Muik et al., 2011, 2012; El-Andaloussi et al., 2012; Gentschev et al., 2012; Schäfer, 2012; Ketzer et al., 2012; Bach et al., 2013; Friedrich et al., 2013; Lacroix et al., 2013; Völker et al., 2013; Weibel et al, 2013. 


\subsubsection{Nicht-virale Vektoren}

Als klassischer nicht-viraler Vektor gilt die sogenannte „nackte“ („,naked“) DNA. Zwar könnte man eine solche DNA heute auch synthetisch herstellen, allerdings wäre das für größere DNA-Abschnitte in relevanten Mengen praktisch kaum durchführbar. Daher wird DNA in der Regel in Form von Plasmiden vermehrt. Bei Plasmiden handelt es sich um ringförmige DNA-Moleküle, die meist zwischen etwa zwei- und zehntausend Nukleotiden (2 bis 10kb) groß sind. Von Plasmiden abgeleitete Moleküle können auch $50 \mathrm{~kb}$ groß sein.

Plasmide kommen natürlicherweise in Bakterien vor. Daher werden auch Laborstämme von Bakterien benutzt, um Plasmide zu vermehren. Aufgrund der extrem schnellen Wachstumsgeschwindigkeit von Bakterien lassen sich mit ihrer Hilfe sehr große Mengen Plasmid-DNA in kürzester Zeit produzieren. Zudem können die Plasmide auch im industriellen Maßstab relativ einfach mit höchster Reinheit und Identität hergestellt werden (Chen et al., 2003). ${ }^{37}$ Es besteht keine Gefahr der Entstehung replikationskompetenter Partikel, von einer Biogefährdung ist deshalb nicht auszugehen. Zusammengenommen machen diese Eigenschaften die Verwendung von Plasmid-DNA aus pharmazeutischer Sicht sehr interessant (Schleef/Blaesen, 2009; Schleef et al., 2010).

Das Grundproblem der nicht-viralen Vektoren ist der Transport in die Zelle. Während virale Vektoren sich natürlicher Mechanismen bedienen, es sich im heutigen Sprachgebrauch quasi um „Bio-Vektoren" handelt, müssen für nicht-virale Vektoren physikochemische Verfahren benutzt werden, um diese in die Zelle zu schleusen. Ein entscheidendes Hindernis hierbei ist die Zellmembran. Sollen die Zellen außerhalb des Körpers (ex vivo) genetisch modifiziert werden, kann beispielsweise kurzzeitig ein starkes elektrisches Feld angelegt werden, welches die Zellmembran für einen Moment löchrig macht und den Plasmiden ein Eindringen ermöglicht (Elektroporation). Bei einem weiteren physikalischen Verfahren werden die Zellen zusammen mit den DNA-Molekülen, welche zuvor mit magnetischen Nanopartikeln gemischt wurden, einem starken Magnetfeld ausgesetzt, welches die DNA in die Zellen dirigiert (Magnetofection). Ein Verfahren, welches auch für den in vivo Gentransfer geeignet ist, sind die sogenannten Genkanonen ( "gene guns"). Hier wird die DNA an kleine Partikel, die meist aus Gold oder Wolfram bestehen, gebunden und wie durch eine Luftdruckpistole in die Zellen geschossen („, biolistic transfection“). Schließlich kann DNA auch direkt in Zellen injiziert werden, was aber natürlich nur in begrenztem Rahmen möglich ist.

Das bekannteste chemische Verfahren ist die Calciumphosphat-Transfektion, bei der die DNA mit diesem Salz präzipitiert wird und die ausgefallenen Kristalle von den Zel-

37 Die deutsche Firma PlasmidFactory ist auch international ein Vorreiter bei der Herstellung hochreiner Plasmidpräparationen für klinische Anwendungen (www.cms.plasmidfactory.com [25.11.2013]). 
len per Endozytose aufgenommen werden. Alternativ dazu werden zur Komplexierung der DNA auch kationische Polymere verwendet (Kasper et al., 2011). Der Einschluss von DNA in Liposomen, welche mit der Zellmembran fusionieren können, liegt der Lipofection zugrunde. Weitere Transfektionsmethoden befinden sich in der Erprobung.

Wie bei viralen wird auch bei nicht-viralen Vektoren nach Wegen gesucht, insbesondere im Hinblick auf in vivo Anwendungen einen zellspezifischen Gentransfer zu gewährleisten. Dazu werden die polymerischen beziehungsweise lipidischen DNA/ RNA-Komplexe mit Proteinen, Peptiden oder kleinen Molekülen gekoppelt, die als spezifische Liganden für die Bindung an die Zielzelle dienen (Ogris/Wagner, 2011). Spezifische Nukleinsäurepartikel, die diesem Konzept folgend generiert werden, werden auch als „artifizielle“ oder „synthetische“ Viren bezeichnet (Wagner, 2004, 2008; Nie et al., 2011). Über die Herstellung solcher Partikel verfolgen unter anderem die Gruppen von Manfred Ogris und Ernst Wagner das Ziel, selektiv Tumorzellen zu transfizieren. Dazu werden Plasmid/Polymer-Komplexe an den Epidermal Growth Factor (EGF), den natürlichen Liganden des EGF-Rezeptors (EGFR) gekoppelt. Mit den so generierten Partikeln kann das Gentransferkonstrukt nunmehr gezielt in EGFR-positive Tumoren transferiert werden (Schaffert et al., 2011; Schäfer et al., 2011; Klutz et al., 2011).

Die physikochemischen Verfahren weisen neben den genannten Vorteilen auch spezifische Nachteile auf: Der wichtigste Nachteil ist die mangelnde Effizienz der meisten Verfahren. Zwar kommt die DNA mit den genannten Verfahren recht erfolgreich durch die Bilipidmembran, jedoch wird sie in der Zelle zumeist schnell abgebaut. Um in den Kern zu gelangen, muss die DNA auch noch die Kernmembran überwinden. Um der unzureichenden Effizienz entgegenzusteuern, werden meist sehr hohe Kopienzahlen der Plasmide verwendet. Dies fördert Rekombinationen und Konkatemerbildung, aber auch teilweise extrem hohe initiale Expressionslevel in transfizierten Zellen. Da Plasmide aus Bakterien stammen, enthalten sie zudem Sequenzbereiche, die zelluläre Abwehrmechanismen aktivieren. Insgesamt sind viele der plasmidbasierten Transfektionsverfahren für die Zellen mit relativ großem Stress verbunden, sodass oft größere Zellverluste entstehen. Zugleich geht die eingebrachte Erbinformation bei Verwendung von Plasmiden nach erfolgreicher Transfektion bei Zellteilungen sehr schnell verloren. Daher sind klassische nicht-virale Vektoren wie Plasmide am ehesten für den transienten Gentransfer und Kurzzeiteffekte (z. B. in Tumorgewebe), aber auch für die genetische Modifikation postmitotischer Gewebe (wie Muskeln) geeignet. Mit einer geringen Wahrscheinlichkeit kommt es allerdings auch nach der DNA-Transfektion zu spontanen Integrationen, deren Häufigkeit durch geeignete Maßnahmen (z. B. Setzen von Schäden im Genom der Zielzelle, Linearisierung der Plasmidmoleküle) erhöht werden kann. Auch kann aufIntegrationen selektioniert werden z zum Beispiel wenn der Vek- 
tor neben dem interessierenden Transgen noch ein Antibiotikaresistenzgen enthält. Allerdings erfolgen diese Integrationen ungerichtet und oft unter Inkaufnahme von Schädigungen des Genoms, sodass ein vergleichsweise hohes Mutageneserisiko besteht.

Um trotzdem einen sicheren permanenten Gentransfer mit physikochemischen Methoden zu erreichen, wurden mehrere Alternativen entwickelt. Eine davon zielt darauf ab, eine sichere Transgeninsertion zu gewährleisten. Dies wird dadurch erreicht, dass spezielle Enzyme (sog. Transposasen) zusammen mit modifizierten mobilen genetischen Elementen (Transposons, auch „springende Gene“) in die Zellen gebracht werden. Die Transposasen erkennen die Transposons und benutzen eine Art „cut and paste“-Mechanismus, um diese in das Zielgenom einzubauen. Ähnlich wie bei Retroviren erfolgt der Einbau ohne chromosomale Rekombinationen. Die Erforschung der Transposition hat in den letzten Jahren große Fortschritte, nicht zuletzt in Richtung klinischer Anwendung gemacht. So gelang es, die Insertionen von Transposons durch den kombinierten Einsatz mit Designernukleasen (siehe unten) gezielt ,in sichere Häfen" zu steuern. Deutsche Wissenschaftlerinnen und Wissenschaftler haben sowohl bei der Entwicklung der Transposontechnologie als auch der Designernukleasen eine Reihe entscheidender Beiträge geleistet. ${ }^{38}$

Ein alternativer Weg, einen permanenten Gentransfer mit nicht-viralen Vektoren zu erreichen, besteht darin, die Plasmide zur autonomen Vermehrung in den Zellen oder aber durch den Einbau von Kernmatrix-Anheftungsregionen (,matrix attachment regions“, MAR) zur dauerhaften Assoziation mit den humanen Chromosomen zu befähigen. Um das Ziel einer autonomen episomalen Replikation zu erreichen, werden in den Vektor entsprechende bakterielle beziehungsweise virale Kontrollelemente eingebaut. Der Vorteil dieses Herangehens ist offensichtlich: Eine Integration in das Zielzellgenom (und die daraus resultierenden möglichen negativen Folgen einer Insertionsmutagenese, siehe oben) ist nicht nötig, um eine dauerhafte Transgenexpression zu gewährleisten. ${ }^{39}$ Auch bei der Entwicklung episomal persistierender Vektoren leisten deutsche Teams nach wie vor wichtige Beiträge (Haase et al., 2010; Voigtlander et al., 2013; Haase et al., 2013).

Eine Reihe bahnbrechender Entdeckungen der Grundlagenforschung der letzten Jahre eröffnet zudem die Möglichkeit, zum Ideal der Gentherapie im Sinne einer „genetischen Chirurgie“ (siehe oben) zurückzukehren. So steht mittlerweile eine Vielzahl

38 Siehe beispielsweise die Arbeiten von Ivics et al., 1997, 2009; Mátés et al., 2009; Grabundzija et al., 2010; Galla et al., 2011; Schierling et al., 2012; Ammar et al., 2012; Voigt et al., 2012; Grabundzija et al., 2013.

39 Die Replikationsfähigkeit der eingebrachten genetischen Elemente stellt allerdings, zumindest theoretisch, auch eine gewisse Biogefährdung dar 
unterschiedlicher sequenzspezifischer Nukleasen (sog. Designernukleasen) ${ }^{40}$ zur Verfügung, welche es erlauben, das Zielzellgenom hochspezifisch zu editieren (Übersicht: Händel/Cathomen, 2011). Alternativ zu den Nukleasen werden zudem natürlich vorkommende Rekombinasen so modifiziert, dass sie neue Zielsequenzen erkennen (Sarkar et al., 2007; Abi-Ghanem et al., 2013).

Das Genomediting mit Nukleasen kann zum Beispiel benutzt werden, um potenziell „schädliche“ Gene auszuschalten. Ein Beispiel ist die Ausschaltung des Chemokinrezeptors CCR5, der als Korezeptor von HIV dient. ${ }^{41}$ Kürzlich wurde gezeigt, dass die Übertragung von Blutzellen eines CCR5-negativen Spenders einen AIDS-Patienten offensichtlich von dessen HIV-Infektion heilen kann (Hütter et al., 2009; Allers et al., 2011). Die gezielte Ausschaltung des CCR5-Gens in Lymphozyten und hämatopoetischen Stammzellen von HIV-Patientinnen und -Patienten wird daher als vielversprechende Strategie zur Gentherapie von AIDS betrachtet (Übersicht: van Lunzen et al., 2011; Buchholz/Hauber, 2013; Stone et al., 2013) und bereits im Rahmen einer klinischen Phase-II-Studie erprobt. ${ }^{42}$

Designernukleasen können aber nicht nur zur Zerstörung von Genen benutzt werden. Wesentlich interessanter könnte es sein, die Nukleasen zu benutzen, um den Ersatz defekter Genabschnitte, also die Genreparatur, durch homologe Rekombination zu stimulieren. Auch neue Gene können mithilfe der Designernukleasen sicherer in das Zielgenom eingebaut werden. Dabei wird deren Sequenzspezifität benutzt, um ein therapeutisches Transgen in einen „sicheren Hafen“ zu dirigieren; auf diese Art wird das Risiko einer Insertionsmutagenese minimiert. ${ }^{43}$ Auch auf Basis der RekombinaseTechnologie (Buchholz, 2009) werden Gentherapieansätze der HIV-Infektion entwickelt (Sarkar et al., 2007; Mariyanna et al., 2012). Sowohl an der Entwicklung unterschied-

40 Designernukleasen bestehen aus jeweils einer DNA-Bindungsdomäne, welche die Spezifität vermittelt, und einer Effektordomäne, welche einen DNA-Doppelstrangbruch induziert, welcher dann von zellulären Reparaturmechanismen erkannt und repariert wird. Abhängig von der Natur der DNAErkennungsdomäne wird zwischen Protein- (Meganukleasen, Zinkfingernukleasen, TAL-EffektorNukleasen) und Nukleinsäure-basierten (CRISPR/Cas-System) Designernukleasen unterschieden.

41 Natürlicherweise fehlt dieser Rezeptor bei ca. 1 \% der Kaukasier (westliche Bevölkerung), die eine homozygote Mutation im CCR5-Gen (CCR5 32$)$ tragen. Betroffene weisen keinerlei Pathologie auf, sind aber weitgehend immun gegen HIV.

42 www.sangamo.com/index.html [25.11.2013].

43 Als ,sicherer Hafen“ gilt z. B. die bevorzugte Integrationsstelle des Wildtyp-AAV auf Chromosom 19, da mit AAV-Insertionen in diesem Lokus keine bekannten negativen Auswirkungen verbunden sind. 
licher Nuklease- als auch Rekombinase-Technologien waren und sind deutsche bzw. in Deutschland tätige Wissenschaftlerinnen und Wissenschaftler führend beteiligt. ${ }^{44}$

Zusammenfassend lässt sich konstatieren, dass eine große Vielfalt an Gentransfervektoren wie auch -methoden existiert. Zugleich gibt es keinen Vektor, der im Sinne eines „magic bullet“ alle Kriterien eines idealen Vektors erfüllen würde. Stattdessen eignen sich die einzelnen Vektoren jeweils unterschiedlich gut für definierte Anwendungen, sodass für viele Gentherapiestrategien ein optimaler Vektor definiert werden kann. In diesem äußerst weiten Feld der Entwicklung klinisch relevanter Gentransferstrategien und -methoden sind eine ganze Reihe deutscher Wissenschaftlerinnen und Wissenschaftler aktiv. Besonders bei der Vektorentwicklung machen sich die Verbindung grundlagenwissenschaftlicher mit Anwendungsforschung in vielen Instituten sowie die ausgezeichnete Vernetzung innerhalb Deutschlands sehr bezahlt. Die Förderung der vernetzten Strukturen, wie im Bereich der Vektorforschung beispielhaft durch das sehr erfolgreiche DFG-Schwerpunktprogramm SPP1230 (,Mechanisms of gene vector entry and persistence“) illustriert, sollte daher unbedingt fortgesetzt werden.

\subsection{Klinische Gentherapie bei ausgewählten Indikationen}

\subsubsection{Monogen bedingte Erkrankungen}

Nach den Rückschlägen am Ende der 1990er Jahre begann mit den ersten unzweifelhaften klinischen Erfolgen in den frühen 2000er Jahren für das Feld der Gentherapie eine Phase der Konsolidierung. Die ersten Durchbrüche wurden beim klassischen Genersatz beziehungsweise der Genaddition (siehe oben) zur Behandlung angeborener, monokausaler schwerer kombinierter Immundefizienzen (SCID) erreicht (Aiuti et al., 2002, 2009; Hacein-Bey-Abina et al., 2002; Gaspar et al., 2004). ${ }^{45}$ Die Konsolidierungsphase wurde vor allem genutzt, um die im ersten Jahrzehnt klinischer Gentherapiestudien gewonnenen Erfahrungen auszuwerten. Aufbauend darauf wurden zum einen die Studienprotokolle optimiert. Zum anderen wurden die technischen Voraussetzungen für eine erfolgreiche klinische Umsetzung vieler im kleinen Maßstab funktionierender

44 Jüngere Arbeiten zum Beispiel Söllü et al., 2010; Mussolino et al., 2011; Mussolino/Cathomen, 2011; Händel et al., 2012; Schierling et al., 2012; Ramirez et al., 2012; Voigt et al., 2012; Holkers et al., 2013; Rahman et al., 2013; Aiuti et al., 2013; Karimova et al., 2013.

45 Auch bei Berücksichtigung der hohen Inzidenz schwerer Nebenwirkungen in den SCID-X1-Studien (fünf Kinder entwickelten Leukämien, die sich glücklicherweise in vier Fällen als gut behandelbar erwiesen) mit den zunächst verwendeten $\gamma$-retroviralen Vektoren sind die Langzeitergebnisse deutlich besser als mit der besten Alternativtherapie, der allogenen Stammzelltransplantation, die mit einer hohen Mortalität und Morbidität verbunden ist (ausführlich Eehse et al., 2011:84 ff.). 
Strategien verbessert, vor allem bezüglich der Effizienz und Sicherheit des Gentransfers beziehungsweise der -vektoren.

In den folgenden Jahren wurde unter anderem von deutschen Gentherapeutinnen und -therapeuten gezeigt, dass das Prinzip der Genaddition auch bei anderen primären Immundefizienzen (PID) wie Chronischer Granulomatose (CGD) oder dem Wiskott-Aldrich-Syndrom (WAS) funktioniert (Ott et al., 2006; Boztug et al., 2010). ${ }^{46}$ Jedoch wurden auch in diesen Studien noch die $\gamma$-retroviralen Vektoren der 1. Generation benutzt, was zur Folge hatte, dass es auch hier nach mehreren Jahren bei mehreren Patientinnen und Patienten zur Leukämieentwicklung infolge einer Insertionsmutagenese kam (Stein et al., 2010; Avedillo Díez et al., 2011). Erstaunlicherweise kam es in der Studie zur Behandlung von ADA-SCID, in der ebenfalls die ,alten“ Vektoren benutzt werden, bisher nicht zu schweren Nebenwirkungen, wobei viele der Personen vor mehr als zehn Jahren behandelt wurden. Das legt nahe, dass auch die zu behandelnde Krankheit selbst einen Einfluss auf das Risiko einer Insertionsmutagenese besitzt.

In jedem Fall wurden die $\gamma$-retroviralen Vektoren der 1. Generation in den letzten Jahren entweder modifiziert ${ }^{47}$ oder durch lentivirale Vektoren ersetzt, um die Wahrscheinlichkeit einer Insertionsmutagenese zu minimieren. Inzwischen wurden die ersten Patientinnen und Patienten mit diesen sicherheitsoptimierten Vektoren behandelt. ${ }^{48}$ Auf Basis der präklinischen Daten aus den verschiedenen Toxizitätsmodellen und anhand der derzeit verfügbaren Ergebnisse der Klonalitätsanalysen besteht die begründete Hoffnung, dass die bisher messbare klinische Wirksamkeit mit einer signifikant geringeren Inzidenz schwerer Nebenwirkungen assoziiert ist.

Insgesamt verfestigt sich die bereits früher getroffene Einschätzung (Fehse et al., 2011:85 ff.), dass sich die Gentherapie bei mehreren monogenen Erbkrankheiten (vor allem PID), für die nur eine hochriskante allogene Stammzelltransplantation als alternative Therapie existiert, in naher Zukunft zur Therapie der 1. Wahl entwickeln dürfte. Auch die Daten für andere monogene Erbkrankheiten (Thalassämie, lysosomale Speichererkrankungen, degenerative Erkrankungen), deren Behandlung mit Blutstammzellen möglich ist, sind teilweise vielversprechend (Cartier et al., 2009; Cavazzana-Calvo et al., 2010; Biffi et al., 2013).

$46 \mathrm{Zu}$ den bereits mit Gentherapie behandelten PID gehören: ADA-SCID, SCID-X1 (auch X-SCID genannt), CGD, WAS und LAD (Leukozyten-Adhäsionsdefizienz); vgl. Kohn, 2010.

47 Insbesondere wurden sogenannte selbst-inaktivierende Vektoren designt, bei denen die starken viralen Promotoren und Enhancer, die fast immer für die Insertionsmutagenese verantwortlich waren, aus den viralen LTR entfernt wurden.

48 Die bisher verfügbaren Daten legen nahe, dass die Vektoren hinsichtlich ihrer Effizienz vergleichbar mit denen der 1. Generation sind (Zhang et al., 2013; Aiuti et al., 2013; Biffi et al., 2013; Hacein-BeyAbina et al., 2013a, b· De Ravin et al., 2013)。 
Gerade im Bereich der Gentherapie angeborener Immundefizienzen existiert eine ausgeprägte internationale Kooperation ${ }^{49}$, die sich unter anderem in dem sehr aktiven "Trans-Atlantic Gene Therapy Consortium" (TAGTC) widerspiegelt. Neben der Koordination wissenschaftlicher Zusammenarbeit sowie präklinischer und klinischer Studien widmet sich dieser Verbund auch der Interaktion mit Regulatoren, um beispielsweise die formalen Voraussetzungen für die Durchführung multizentrischer Studien zu vereinheitlichen (Williams et al., 2010). Im TAGTC sind auch eine Reihe deutscher Akteure aktiv, unter anderem auch an bei koordinierten Vorbereitung und Durchführung multizentrischer Studien zur Behandlung von Immundefizienzen. Allerdings hat sich die internationale Führung im Bereich der klinischen Anwendung genetisch modifizierter Blutstammzellen in Europa deutlich nach Italien ${ }^{50}$, Frankreich und England verlagert, die zusammen mit den USA das Gros aller Studien koordinieren.

Bald nach den Erfolgen im Kontext der genetischen Korrektur von Blutstammzellen wurden auch die ersten Durchbrüche bei weiteren Erbkrankheiten berichtet. Große Aufmerksamkeit in der Öffentlichkeit fanden Berichte zur Gentherapie angeborener degenerativer Augenkrankheiten ${ }^{51}$ mit AAV-Vektoren, die das Gen für das bei den Patienten defiziente Retinalpigmentepithel-spezifische 65-kD Protein übertrugen. Erfolgreiche Phase I-Studien wurden unabhängig in mehreren internationalen Labors durchgeführt (Bainbridge et al., 2008; Maguire et al., 2008; Cideciyan et al., 2008). Folgeuntersuchungen zeigen, dass die Verbesserung der Sicht mindestens drei Jahre erhalten bleibt (Jacobson et al., 2012). Genetisch bedingte degenerative Augenkrankheiten sind allerdings sehr selten. Die potenzielle Bedeutung des Ansatzes liegt in seiner möglichen Übertragbarkeit auf alters- oder diabetesbedingte Makuladegeneration. Dass zuvor noch einige Probleme zu lösen sind, geht aus neuen Berichten hervor, nach denen trotz erfolgreicher Gentherapie die Degeneration der Retina nicht gestoppt werden konnte (Cideciyan et al., 2013).

Eine andere Erbkrankheit, für die bemerkenswerte klinische Fortschritte berichtet wurden, ist die Hämophilie B, bei der der fehlende Gerinnungsfaktor IX durch AAV-Gen-

49 Dies wird sicher auch durch den Umstand gefördert, dass die meisten dieser Krankheiten extrem selten sind.

50 Im Oktober 2010 gaben GlaxoSmithKline und die beiden italienischen gemeinnützigen Stiftungen Telethon und San Raffaele die Unterzeichnung eines Kooperationsabkommens zur Entwicklung gentherapeutischer Ansätze für die Behandlung monogenisch vererbter PID bekannt. Vgl. http://us.gsk. $\mathrm{com} / \mathrm{html} /$ media-news/pressreleases/2010/2010_pressrelease_10113.htm [25.11.2013].

51 Aufgrund mehrerer Eigenschaften gilt das Auge als nahezu ideales Zielorgan der Gentherapie: Es ist klein, das heißt, es müssen nur relativ wenige Zellen korrigiert werden; es ist sehr gut zugänglich und zudem teilweise immunprivilegiert, das heißt auch die Gefahr von Immunreaktionen gegen den Vektor oder modifizierte Zellen ist gering. 
transfer ersetzt wird (Nathwani et al., 2011). Ähnlich wie die zuvor beschriebene Gentherapie der Netzhautdegeneration illustriert auch die Gentherapie für Hämophilie den Erfolg des Bench-to-Bedside-to-Bench-Prinzips: Die ersten AAV-Vektoren waren schon in den 1990er Jahren entwickelt und präklinisch mit großem Erfolg bis in das Hundeund sogar Primatenmodell getestet worden. Umso größer war die Enttäuschung im Feld, als die erste klinische Anwendung in einem ziemlichen Desaster endete, weil die Patientinnen und Patienten sehr schnell eine starke T-Zellantwort gegen die transduzierten Zellen entwickelten. Wie sich herausstellte, infizieren sich praktisch alle Menschen als Kinder mit dem benutzten AAV-Serotyp (AAV2), nicht aber die zuvor erfolgreich behandelten Hunde und Primaten. Das hatte zur Folge, dass die Applikation der AAV-Vektoren bei den Patientinnen und Patienten zu einer Reaktivierung virusspezifischer Memory T-Zellen führte, die sich dann gegen die offensichtlich über längere Zeiträume mit viralen Proteinen beladenen Zellen richtete (Manno et al., 2006; Vandenberghe et al., 2006). So mussten die Wissenschaftlerinnen und Wissenschaftler zurück in die Labore, bis schließlich gezeigt war, dass die Korrektur der Hämophilie genauso effizient mit anderen Faktor-IX-kodierende AAV-Serotypen funktioniert, diese aber keine oder nur eine moderate und beherrschbare Immunreaktion auslösen (Nathwani et al., 2011).

Die Gentherapie von Erbkrankheiten machte Ende 2012 außerdem durch die kommerzielle Zulassung des ersten Gentherapeutikums in der westlichen Welt (Glybera) durch die europäische Arzneimittelagentur Schlagzeilen. Bei Glybera (Alipogene tiparvovec) handelt es sich um einen AAV-Vektor, welcher das bei der äußerst seltenen Lipoproteinlipase-Defizienz fehlende Enzym LPL substituiert.

Insgesamt lässt sich konstatieren, dass bei der Behandlung monogen bedingter Erbkrankheiten einige teilweise sehr bemerkenswerte Fortschritte gemacht wurden. Wenn auch „psychologisch wichtig“ für das Feld der Gentherapie, sind diese Krankheiten in der Regel doch sehr selten und machen daher auch weniger als $10 \%$ der Gentherapie-Anwendungen aus (siehe Tabelle 1). 
Tabelle 1: Indikationen für gentherapeutische Studien

\begin{tabular}{|l|c|}
\hline Krebserkrankungen & $64,2 \%$ \\
\hline Herz-Kreislauf-Erkrankungen & $8,1 \%$ \\
\hline monogene Erbkrankheiten & $8,9 \%$ \\
\hline Infektionskrankheiten & $8,2 \%$ \\
\hline neurologische Krankheiten & $1,9 \%$ \\
\hline Augenkrankheiten & $1,4 \%$ \\
\hline entzündliche Erkrankungen & $0,7 \%$ \\
\hline andere Krankheiten & $1,4 \%$ \\
\hline
\end{tabular}

Stand Juli 2013, Wiley-Datenbank.

\subsubsection{Maligne Erkrankungen}

Der Schwerpunkt bei der Entwicklung und klinischen Erprobung gentherapeutischer Ansätze liegt seit langem auf der Behandlung maligner (bösartiger) Krankheiten; seit Jahren liegen sie bei circa zwei Drittel aller klinischen Studien (siehe Kapitel 6.5.2, GT08). Dies spiegelt natürlich die gesamtgesellschaftliche Bedeutung der Krebskrankheiten wider. Zugleich ist Krebs als Ziel gentherapeutischer Intervention auch deshalb wesentlich interessanter als zum Beispiel die gesellschaftlich vergleichbar bedeutsamen Herz-Kreislauf-Krankheiten, weil er in vielerlei Hinsicht als erworbene genetische Erkrankung betrachtet werden kann. ${ }^{52}$ Zudem hoffen Gentherapeuten wie Onkologen, dass sie sich für die Krebsbehandlung das Immunsystem zunutze machen können. Als Zellen des Blutsystems lassen sich Immunzellen vergleichsweise einfach isolieren und genetisch modifizieren.

Entsprechend kann man für die Krebsgentherapie drei wesentliche Strategien ausmachen (Kammertoens et al., 2005; Liu/Deisseroth, 2006): ${ }^{53}$

1. unmittelbare Zerstörung der Krebszellen durch die Gentherapie

2. Aktivierung des Immunsystems mit dem Ziel der Vernichtung der Tumorzellen

3. Zerstörung von „supportiven“ Geweben, die der Tumor für sein Wachstum benötigt (Tumorstroma einschließlich Blutgefäße)

52 Allerdings liegen Krebserkrankungen im Gegensatz zu monogen bedingten Erbkrankheiten in der Regel multiple und oft komplexe genetische Veränderungen zugrunde.

53 Die Unterteilung ist nicht absolut: Zum Beispiel setzen die Gentherapeuten bei der ersten Strategie in der Regel darauf, dass die unmittelbare Zerstörung der Krebszellen zu einer sekundären Aktivierung des Immunsystems führt. 
Gemeinsam ist allen drei Strategien, dass versucht wird, der Komplexität der Krebserkrankung dadurch zu entkommen, dass einzelne, hervorstechende und möglichst für das Überleben der Tumorzellen essenzielle Eigenschaften adressiert werden. Aus Platzgründen soll im Folgenden nur auf die ersten beiden Strategien kurz eingegangen werden (ausführlicher in Fehse et al., 2011:92-100).

1. Prinzipiell lassen sich Tumorzellen auf verschiedenen Wegen direkt umbringen: beispielsweise durch das Einbringen konditionell toxischer (z. B. Suizidgene) oder Apoptose-fördernder Gene. Die Schwäche dieses Ansatzes ist augenscheinlich - in vivo erscheint es faktisch unmöglich, alle bis zur letzten Tumorzelle genetisch zu modifizieren. Daher hofft man bei diesen Therapien auf sogenannte Bystander-Effekte, die zu einer Zerstörung auch nicht transduzierter Zellen führen. Bystander-Effekte können pharmakologischer Natur sein, zum Beispiel wenn das in einer Suizidgen-transduzierten Zelle produzierte Zellgift auch an benachbarte, nicht-transduzierte Zellen weitergegeben wird (Miletic et al., 2007; Preuss et al., 2011). Solche Bystander-Effekte sind lokaler Natur und damit vor allem für fest umgrenzte, nicht-metastasierende Tumoren interessant. Wenn die Zerstörung eines Teils der Tumorzellen zu einer lokalen Entzündung und einer folgenden Aktivierung tumorspezifischer Immunzellen (vor allem tumorspezifischer T-Lymphozyten) führt, sind auch immunologische BystanderEffekte möglich, die dann sogar über große Distanzen (z. B. bei Metastasen) funktionieren könnten.

Ein markantes Beispiel für eine auf die Tumorzerstörung gerichtete Gentherapie war Mitte der 1990er die erste Phase-III-Studie im Feld. Diese zielte auf die Zerstörung von unheilbaren Hirntumoren (Glioblastomen) durch retrovirale Transduktion mit einem Suizidgen, das für das Enzym Thymidinkinase (TK) im Herpes-simplex-Virus (HSV) codiert, und anschließende Applikation des korrespondierenden Prodrugs Ganciclovir. Aufgrund unzureichender technischer Voraussetzungen endete diese von der Firma Amgen gesponserte Studie allerdings mit einem Misserfolg (Rainov, 2000) und führte schließlich sogar zum seinerzeitigen Ausstieg der großen Pharmaindustrie aus der Gentherapie. Trotzdem wird das Suizidgenprinzip in der Onkologie weiter verfolgt; auch eine Reihe von Arbeiten aus Deutschland zielt auf die Verbesserung verschiedener seiner Aspekte (Preuss et al., 2010, 2011; Niess et al., 2011).

Ein alternativer Ansatz des direkten Tumorkillings beruhte auf dem adenoviralen Gentransfer des in fast allen menschlichen Tumoren defekten Tumorsuppressorgens p53 in die Tumorzellen. Die Re-Expression von p53 soll zur Differenzierung oder zum Zelltod der malignen Zellen führen. Adenovirale p53-Vektoren wurden 2003 in der VR China als weltweit erstes kommerzielles Gentherapieprodukt (Gendicine) zugelassen 
(Wilson, 2005). Nach neueren Publikationen chinesischer Teams ist der Vektor vor allem im Kontext von Kombinationstherapien mit Radio- und/oder Chemotherapie wirksam (Yang et al., 2010; Yu et al., 2010; Xie et al., 2010; Chen et al., 2011 ${ }^{54}$ ).

Die Nutzung konditionell replizierender, onkolytischer Viren (siehe oben) stellt ein vielversprechendes Konzept zur Lösung des Problems der mangelnden Erreichbarkeit auch der letzten Tumorzelle dar. Auch wenn die Datenlage in Bezug auf das bereits zugelassene adenovirale onkolytische Virus Oncorine (siehe oben) nach wie vor unzureichend ist (Übersicht: Ma et al., 2009; Liang, 2012), ist die kommerzielle Vermarktung offenbar in vollem Gange. ${ }^{55}$ Nach den bisher vorgestellten Ergebnissen verläuft auch in mehreren westlichen Ländern die klinische Testung unterschiedlicher onkolytischer Viren durch mehrere Firmen im Rahmen großer multizentrischer Studien bisher sehr erfolgreich (siehe oben).

2. Schon die allererste klinische Gentherapie-Studie ${ }^{56}$ im Jahr 1989 diente der Verbesserung der Immuntherapie bösartiger Lymphome (Rosenberg et al., 1990). In vielen der frühen Gentherapiestudien wurde versucht, die Tumore besser für das Immunsystem sichtbar zu machen. Auch die ersten beiden klinischen Gentherapiestudien in Deutschland (1994) zielten auf die Aktivierung des Immunsystems durch die Einführung immunstimulatorischer Gene in die Tumorzellen. Diese wie eine Reihe anderer initialer Studien zeigten jedoch nur sehr limitierte klinische Effizienz, nicht zuletzt, weil sich langsam entwickelnde Tumore eine Reihe nur schwer durchbrechbarer Toleranzmechanismen in ihrem „Wirt“ induziert haben. Das Konzept wird aber unter anderem durch die Firma Aduro Biotech mit der GM-CSF-exprimierenden Tumor-Zelllinien („GVAX“) weiterverfolgt, ${ }^{57}$ welche gerade vielversprechende Daten der Phase-II-Studie beim Pankreas-Karzinom beim ASCO-Meeting vorgestellt hat. ${ }^{58}$

Im umgekehrten Ansatz wird versucht, Immunzellen genetisch so zu modifizieren, dass sie eine effiziente Immunantwort gegen auf dem Tumor präsente (Tumor-assoziierte), idealerweise Tumor-spezifische Antigene (Tumorantigene) ausüben. Dazu werden die T-Lymphozyten der Erkrankten mit einem neuen (tumor-)antigenspezifischen Rezeptor ausgestattet, das heißt sie werden faktisch „umprogrammiert“ ${ }^{59}$ Die naheliegendste

54 Dieser Artikel ist nur als Vorabveröffentlichung online erhältlich [Epub ahead of print], nicht aber in einer regulären Ausgabe der Zeitschrift.

55 www.sunwaybio.com.cn/en/product.html [11.11.2013].

56 Im engeren Sinne handelte es sich eigentlich um eine Genmarkierungsstudie bei tumorinfiltrierenden Lymphozyten (TIL).

57 www.adurobiotech.com/ [11.11.2013].

58 http://meetinglibrary.asco.org/content/112374-132 [11.11.2013].

59 Als Teil des adaptiven Immunsystems verfügen alle T-Zellen über eine eigene Antigenspezifität, die nach dem Schlüssel-Schloss-Prinzip durch den endogenen T-Zellrezeptor (TCR) vermittelt wird. 
Möglichkeit einer solchen Umprogrammierung besteht darin, den in den T-Lymphozyten jeweils vorhandenen T-Zell-Rezeptor (TCR) durch einen neuen, tumorspezifischen zu ersetzen. Solche TCRs können zum Beispiel aus Patientinnen und Patienten gewonnen werden, die spontan eine starke Immunantwort gegen den Tumor entwickelt haben. Spontanregressionen aufgrund einer Immunantwort werden immer wieder beim Melanom (schwarzer Hautkrebs) berichtet. Um den richtigen TCR zu identifizieren, müssen im Prinzip T-Zell-Klone isoliert werden, die gegen die Tumorzellen reagieren. ${ }^{60}$ Die DNA dieser Zellen dient dann als Matrize für die Amplifikation des TCRs. Da jeder TCR aus zwei Ketten ( $\alpha$ und $\beta$ ) besteht, müssen entsprechend auch beide Gene amplifiziert und in die Zielzellen übertragen werden, um letztere umzuprogrammieren (Übersicht: Jorritsma et al., 2011; Park et al., 2011). Tatsächlich gelang durch Nutzung dieses Prinzips vor einigen Jahren der erste große Behandlungserfolg bei als ,austherapiert“ geltenden Melanom-Patienten (Morgan et al., 2006; Übersicht: Lagisetty/Morgan, 2012). Inzwischen wurde die Strategie bei einer Reihe weiterer maligner Neoplasien mit teilweise beeindruckenden Ergebnissen angewendet (Parkhurst et al., 2011; Robbins et al., 2011).

Allerdings hat der TCR-Gentransfer eine Reihe von Limitationen: Ein offensichtliches Problem stellt die Präsenz eines endogenen TCRs in den „umprogrammierten“ Lymphozyten dar. Dies führt nicht nur zu Expressionsproblemen, da beide Rezeptoren um dieselben Kofaktoren konkurrieren müssen, sondern auch zum Risiko von Fehlpaarungen (Mispairing), das heißt der Paarung der endogenen $\alpha$ - mit der exogenen $\beta$-Kette oder umgekehrt. So können theoretisch in transduzierten Zellen vier verschiedene TCRs gleichzeitig gebildet werden. Neben dem offensichtlichen Verlust an Effizienz birgt die Bildung völlig neuer Kombinationen von Rezeptorketten das Risiko, dass autoreaktive (gegen den eigenen Körper gerichtete) TCR-Spezifitäten entstehen. Da für eine solche T-Zell-Therapie initial viele Millionen unterschiedlicher T-Lymphozyten mit den neuen TCR-Ketten transduziert werden, ist dieses Risiko realer, als es auf den ersten Blick scheinen mag. Tatsächlich wurde im Mausmodell die Entstehung einer tödlichen Spender-gegen-Wirt Krankheit nach der Infusion TCR-modifizierter T-Lymphozyten beobachtet, die sich auf ein Rezeptorketten-Mispairing zurückführen ließ (Bendle et al., 2010). Eine solche Nebenwirkung kann durch ein intelligentes Design der eingebrachten TCR-Ketten, welches die Paarung mit endogenen Rezeptorketten verhindert, weitgehend ausgeschlossen werden (ebd.). Seit Kurzem besteht auf der Basis der Designernukleasen die Möglichkeit, die endogenen TCRs auszuschalten, wodurch auf

60 Es können aber auch TCR benutzt werden, die aus Mäusen gewonnen wurden (Johnson et al., 2009). 
einen Schlag mehrere der oben beschriebenen Probleme gelöst werden (Provasi et al., 2012).

Jedoch gilt für die Idee des TCR-Gentransfers eine weitere grundlegende Einschränkung: T-Zell-Rezeptoren erkennen ihr spezifisches Antigen ausschließlich, wenn dieses korrekt vom zugehörigen MHC-Molekül ${ }^{61}$ präsentiert wird. Daher funktioniert der TCR-Gentransfer auch nur bei solchen Patientinnen und Patienten, die das zum TCR passende HLA-Molekül auf ihren Zellen tragen. Zwar gibt es einige HLA-Moleküle, die bei bestimmten Bevölkerungsgruppen gehäuft vorkommen (wie HLA-A2 bei Westeuropäern), aber trotzdem bedeutet dies, dass ein funktionierender TCR immer nur für eine mehr oder weniger kleine Patientengruppe nutzbar ist. Ein weiteres spezifisches Problem der Assoziation der Immunantwort mit dem HLA-System besteht bei der Krebsimmuntherapie darin, dass maligne Zellen dazu neigen, die Expression ihrer HLAMoleküle herunter zu regulieren (Uttenthal et al., 2012).

Viele der oben für den TCR-Gentransfer genannten Probleme treten nicht auf, wenn statt eines TCR ein neuer, artifizieller Rezeptor in die T-Zellen eingebracht wird. Vereinfacht gesagt wurde bei solchen „chimären“ Antigenrezeptoren (CARs, auch T-bodies) die Antigenerkennungsdomäne des TCR durch die eines monoklonalen Antikörpers ersetzt (Eshhar et al., 1993; Friedmann-Morvinski et al., 2005). Durch die Nutzung von meist in anderen Organismen gewonnenen hochspezifischen monoklonalen Antikörpern kann das Prinzip der adoptiven Immuntherapie somit auf Antigene erweitert werden, gegen die normalerweise eine Toleranz besteht (Xue/Stauss, 2007). Allerdings können CARs im Gegensatz zu TCRs nur solche Antigene erkennen, die auf der Zelloberfläche exprimiert werden. Da die Verbindung zwischen TCR und Antikörper per se unphysiologisch ist, funktionierte bei den ersten Konstrukten auch die Signalübertragung in die T-Zelle nur unzureichend - die reaktiven T-Zellen gingen sehr schnell verloren. Dieses Problem scheint bei CARs der 2. und inzwischen 3. Generation aber weitgehend gelöst (Büning et al., 2010; Curran et al., 2012; Uttenthal et al., 2012). Tatsächlich wurden in den letzten Jahren aufsehenerregende klinische Ergebnisse mit CARs, vor allem einem CD19-CAR bei Leukämien erzielt (Porter et al., 2011; Kalos et al., 2011; Grupp et al., 2013). ${ }^{62}$

Ein grundsätzliches Problem jeder Krebsimmuntherapie - sowohl mit TCRs als auch mit CARs - besteht darin, dass es kaum „echte“ Tumorantigene gibt, also Antigene, die

61 MHC bedeutet „major histocompatibility complex“, beim Menschen HLA-Moleküle (Human Leukocyte Antigen), auch Transplantationsantigene genannt, da sie definierend für die Unterscheidung zwischen „selbst“ und „fremd“ sind.

62 Auch hier führten die ausgezeichneten klinischen Daten zum Einstig von „big pharma“: Die CD19CAR-Strategie wurde zwischenzeitlich von Novartis übernommen, www.novartis.com/newsroom/ media-releases/en/2012/1631944.shtml [25,11,2013]. 
ausschließlich auf den Tumorzellen exprimiert werden und auf deren Expression die malignen Zellen idealerweise angewiesen sind, sodass sie das Gen nicht einfach abschalten können. Stattdessen werden in der Realität eher Tumor-assoziierte Antigene identifiziert, die auch auf einer größeren oder kleineren Zahl der gesunden Zellen zu finden sind. In den meisten Fällen wird sich die auf den Patienten übertragene neue Immunreaktivität also auch gegen gesunde Zellen richten (sog. „on-target“ Toxizität). Ein Beispiel ist der oben erwähnte, äußerst wirksame CD19-CAR. CD19 wird regelhaft auf chronischen B-Zell-Leukämien sowie einigen akuten Leukämien exprimiert, aber auch auf gesunden B-Zellen. Werden die Patientinnen und Patienten mit CD19-CARtransduzierten T-Zellen behandelt, können die T-Zellen im Idealfall - wie bei einigen Patienten beobachtet - auch extrem fortgeschrittene Leukämien vollständig eradizieren. ${ }^{63}$ Offensichtlich etablieren sich dabei auch Gedächtniszellen, sodass die Wiederkehr CD19-positiver Zellen auch nach der Behandlung sehr effizient unterdrückt wird. Das trifft sowohl auf die Leukämiezellen zu, zumindest, wenn es ihnen nicht gelingt, das CD19-Molekül abzuschalten, als auch auf die gesunden B-Lymphozyten. Vor dem Hintergrund einer tödlich verlaufenden Krankheit ist der Verlust der B-Zellen und damit eines Teils des adaptiven Immunsystems akzeptabel, aber besonders bei jungen Patientinnen und Patienten auf lange Sicht nicht unproblematisch. ${ }^{64}$ Noch gefährlicher wird die unerwünschte Reaktivität, wenn die Expression der Zielantigene auch auf Zellen und Geweben erfolgt, bei denen das vorher nicht bekannt war. Schon in den ersten klinischen Studien mit TCRs und CARs wurde immer wieder von unerwünschten, teilweise sehr schweren Nebenwirkungen berichtet (Lamers et al., 2006; Morgan et al., 2010; Parkhurst et al., 2011). Auch in neueren Studien kam es zu schwersten Nebenwirkungen bis hin zu Todesfällen (Morgan et al., 2013; Stauss/Morris, 2013). Zudem belegen die neueren Studien das Risiko eines Zytokinsturms bei der Anwendung von CAR-transduzierten T-Zellen (Büning et al., 2010; Kochenderfer et al., 2012). Für die klinische Anwendung von TCRs und CARs kommt es deshalb entscheidend darauf an, solche Tumor-assoziierten Antigene zu wählen, die infolge der Immuntherapie zu einem Minimum an Nebenwirkungen führen (Stauss/Morris, 2013).

Auf dem Gebiet der adoptiven Immuntherapie sind auch mehrere deutsche Gruppen, nicht zuletzt im Rahmen von Verbundprojekten wie dem europäischen Konsortium

63 Mehrere Patientinnen und Patienten entwickelten dadurch Probleme, dass die infundierten CD19-CAR-T-Zellen so extrem potent waren, dass auf einmal zu viele Tumorzellen zerstört wurden. Der gleichzeitige Zerfall einer riesigen Zahl an malignen Zellen führte zu einem sogenannten Tumorlysesyndrom (Porter et al., 2011).

64 Aus B-Zellen werden die Antikörper-produzierenden Plasmazellen generiert. Antikörper gewährleisten u. a. den langfristigen/Schutz yor Infektionserregern, zum Beispiel nach Impfungen. 
ATTACK ${ }^{65}$ und dem DFG-Transregio "Grundlagen und Anwendungen der adoptiven TZell-Therapie ${ }^{\text {"66 }}$ aktiv. ${ }^{67}$ Zudem nehmen deutsche Forscherinnen und Forscher auch in diesem Bereich seit Jahren eine führende Position bei der Untersuchung möglicher unerwünschter Nebenwirkungen des Gentransfers ein. Dabei konnten sie unter anderem nachweisen, dass das inhärente Risiko einer Insertionsmutagenese nach Gentransfer mit integrierenden Vektoren bei T-Lymphozyten vergleichsweise klein ist (Newrzela et al., 2008, 2011, 2012; Biasco et al., 2011; Heinrich et al., 2013). Diese Untersuchungen wurden zum Teil durch das DFG-Schwerpunktprogramm 1230 (siehe oben) unterstützt.

\subsection{Problemfelder und Indikatoren im Bereich der Gentherapie}

\subsubsection{Einführung und Übersicht}

Diese eben beschriebenen Entwicklungen in der Vektorologie beziehungsweise die Erfolge der klinischen Anwendung lassen sich durch - im Wortsinne - zahlreiches Datenmaterial objektivieren. Hierfür arbeiten wir seit Jahren mit dem sogenannten Problemfelder- und Indikatorenmodell: Die Erhebung der Problemfelder für die Gentherapie erfolgte mit dem Ziel, eine öffentlich wahrnehmbare Gesamtschau auf das Thema Gentherapie in Deutschland zu erhalten und entsprechend abzubilden. Um dies zu gewährleisten, wurde ein repräsentativer Ausschnitt der medialen Öffentlichkeit gewählt, der sich auch an der Perspektive des interessierten Laien orientierte (siehe Kapitel 2). Die so eruierten Texte wurden inhaltsanalytisch ausgewertet, verschlagwortet und zu Problemfeldern zusammengefasst; Abbildung 1 zeigt die so eruierten Problemfelder sowie deren quantitative Gewichtung in den untersuchten Texten auf. ${ }^{68}$

65 www.attack-cancer.org/ [25.11.2013].

66 www.sfb-tr36.de [25.11.2013].

67 Einzelne Studien hierzu sind Kieback et al., 2008; Leisegang et al., 2010; Anders et al., 2011; Schmidt et al., 2011; Kofler et al., 2011; Rappl et al., 2012; Spranger et al., 2012; Wilde et al., 2012; Mueller et al., 2012; Maliar et al., 2012; Zhou et al., 2012; Chmielewski et al., 2012, 2013; Dössinger et al., 2013; Berdien et al., 2013; Hombach et al., 2013; Krebs et al., 2013; Nauerth et al., 2013.

68 Die Abbildung dient in erster Linie der Veranschaulichung der Komplexität und Verwobenheit einzelner Aspekte, die im Rahmen gentherapeutischer Entwicklungen in Deutschland öffentlich relevant sind; sie ist dem Korpus immanent eine inhaltliche Momentaufnahme. 
Abbildung 1: Aktuelle Problemfelder zur Gentherapie in Deutschland

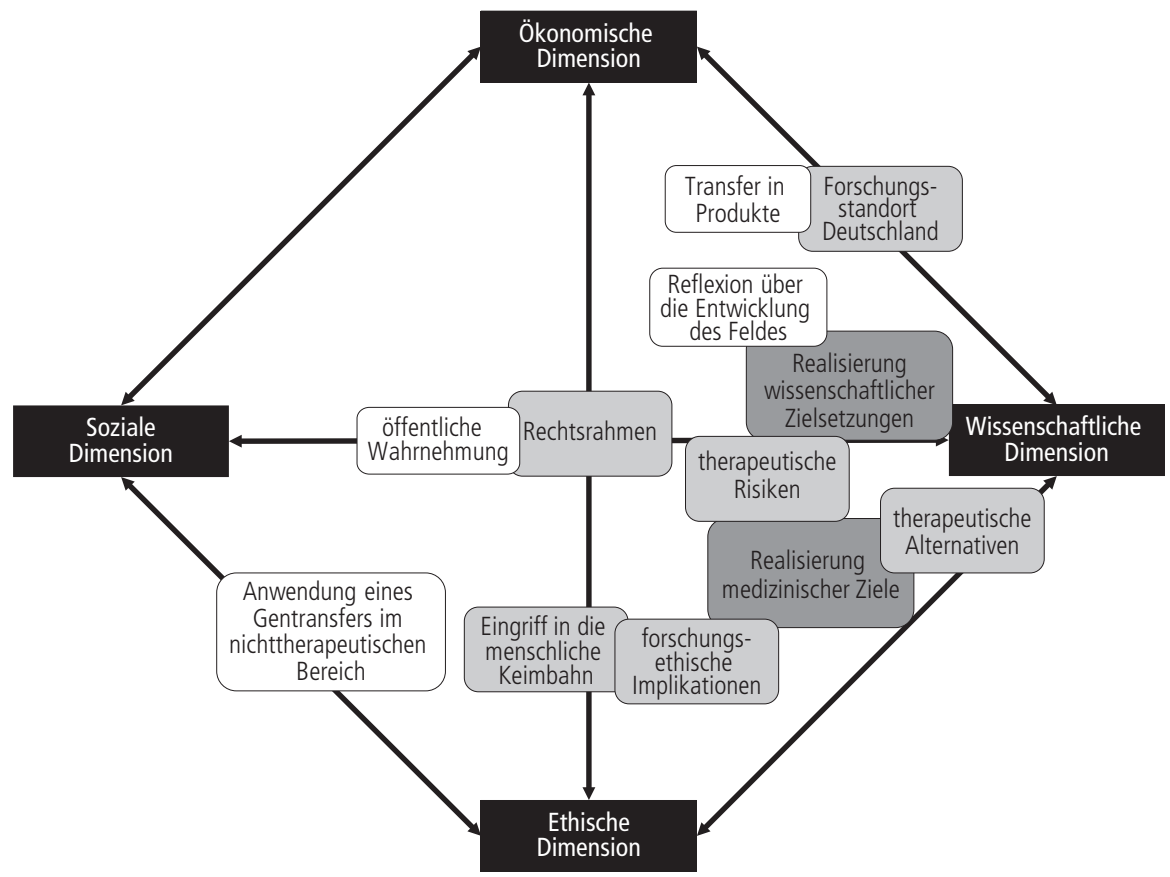

Als interessant erweist sich - im Vergleich zur letzten Erhebung für den Themenband 2011, vgl. Domasch/Fehse, 2011:38 - erneut, dass in der öffentlichen Wahrnehmung immer noch ein Fokus auf der wissenschaftlichen Dimension des Feldes mit Bezug zu ethischen Fragestellungen erkennbar ist: Obwohl einige Verschiebungen des medialen Diskurses sichtbar werden (siehe unten), dominieren nach wie vor die Realisierung wissenschaftlicher und medizinischer Zielstellungen die Diskussion. Die Verortung des Forschungsstandortes Deutschland spielt dabei immer noch eine zentrale Rolle ebenso wie therapeutische Risiken bzw. Alternativen oder forschungsethische Implikationen, wenn über Gentherapie berichtet wird. Dies ist insofern wenig erstaunlich, als dass die Entwicklungen des Feldes, zumal im eigenen Land, naturgemäß medial begleitet werden und dabei - für medizinisch relevante Forschungen - die Risikoabschätzung immer eine zentrale Rolle spielt.

Mit der erkenntnistheoretischen wie technischen Weiterentwicklung des Feldes nehmen die Diskussionen um den Eingriff in die menschliche Keimbahn sowie um Belange der rechtlichen Regulierung zu. Vor allem Fragen des gesetzgeberischen Rahmens sowie der Durchführungsbestimmungen für zum Beispiel klinische Versuche steigen propor- 
tional mit zunehmend klinischen Anwendungen (siehe Kapitel 6.4). Fragen von konkreter Produktentwicklung oder die eigene Reflexion über die Entwicklung des Feldes rücken dagegen in den Hintergrund; Themen wie die öffentliche Wahrnehmung ${ }^{69}$ der Gentherapie in Deutschland oder eine Anwendung des Gentransfers in nicht-therapeutischen Kontexten finden sich nur vereinzelt. Die Problemfelder Verteilungsgerechtigkeit sowie Kostenentwicklung/gesundheitsökonomische Aspekte, die bei der letzten Erhebung noch den medialen Diskurs prägten, spielen nunmehr keine Rolle.

Während das Feld „Gentherapie in Deutschland“ mittels verschiedener Problemfelder beschrieben werden kann, können einzelne Problemfelder ihrerseits mithilfe sogenannter Indikatoren konkret ausgeleuchtet werden (siehe Kapitel 2). Da die zu beschreibenden Sachverhalte sehr heterogen sind, gilt es stets, sogenannte Systeme von Indikatoren zu ermitteln, die dann in einen kohärenten Bezugsrahmen - hier jeweils Problemfelder - eingebunden werden. Dabei sind nicht zwangsweise für alle theoretisch sinnvollen Indikatoren entsprechende Daten auffind- beziehungsweise erhebbar; zudem gilt es in methodischer Hinsicht auf folgende Kriterien zu achten: statistische Sicherheit, Differenziertheit, zeitliche und räumliche hohe Auflösung, methodisch saubere und nachvollziehbare sowie kostengünstige Erhebung und Eindeutigkeit (Hucho et al., 2005:19 f.). Vor diesem Hintergrund wird deutlich, dass für einige der genannten Problemfelder sich nur schwer messbare Kenngrößen ermitteln lassen (z. B. Rechtsrahmen). Tabelle 2 leistet einen Überblick, welche Problemfelder anhand welcher Indikatoren beschrieben werden können; die Sortierung erfolgt wie immer nach den vier oben gewählten Dimensionen (vgl. Domasch/Osterheider, 2011:257 f.); GT bezeichnet dabei "Gentherapie“ - in Abgrenzung zu thematisch anderen Indikatoren (z. B. SB für „Synthetische Biologie")

69 Mit diesem Stichwort werden die früher getrennt gelisteten Problemfelder Akzeptanz/Bewertung in der Bevölkerung sowie Dialog mit der Gesellschaft zusammengefasst. 
Tabelle 2: Problemfelder zur Gentherapie in Deutschland und Indikatoren zu ihrer Beschreibung

\begin{tabular}{|c|c|c|}
\hline Problemfeld & These & Indikatoren") \\
\hline \multicolumn{3}{|c|}{ im Kreuzfeld aller Dimensionen } \\
\hline $\begin{array}{l}\text { öffentliche } \\
\text { Wahrnehmung }\end{array}$ & $\begin{array}{l}\text { Die beständige Information und Teilhabe } \\
\text { der Menschen an den aktuellen Entwicklun- } \\
\text { gen der gentherapeutischen Forschung ist } \\
\text { selbstverständlicher Bestandteil gesamtge- } \\
\text { sellschaftlicher Aushandlungsprozesse; sie hat } \\
\text { Auswirkungen auf die Bewertung/Akzeptanz } \\
\text { einer Technologie. }\end{array}$ & $\begin{array}{l}\text { Bewertung der Gentherapie in Deutsch- } \\
\text { land (GT-01) } \\
\text { Grad der Unterstützung der Gentherapie } \\
\text { (GT-02) } \\
\text { Anzahl der verfügbaren Bücher zum } \\
\text { Thema Gentherapie (GT-15)* } \\
\text { Neuerscheinungen zum Thema Genthe- } \\
\text { rapie (GT-16)* } \\
\text { Internetpräsenz zum Thema Genthera- } \\
\text { pie (GT-18)* } \\
\text { Mediale Präsenz zum Thema Genthera- } \\
\text { pie (GT-19)* }\end{array}$ \\
\hline Rechtsrahmen & $\begin{array}{l}\text { Der rechtliche Rahmen auf nationaler und } \\
\text { europäischer Ebene bestimmt über die } \\
\text { Zulässigkeit von Gentherapeutika und definiert } \\
\text { ihren Einsatz bzw. formuliert dafür notwendige } \\
\text { Rahmenbedingungen. }\end{array}$ & $\begin{array}{l}\text { nationale und internationale Gesetzgebung } \\
\text { (Art und Anzahl) }\end{array}$ \\
\hline \multicolumn{3}{|c|}{ Wissenschaftliche Dimension } \\
\hline $\begin{array}{l}\text { Realisierung } \\
\text { wissenschaft- } \\
\text { licher Zielset- } \\
\text { zungen }\end{array}$ & $\begin{array}{l}\text { Wissenschaftliche Zielsetzungen und konkrete, } \\
\text { etablierte Anwendungen sind für Laien schwer } \\
\text { zu unterscheiden. Zum Wesen wissenschaft- } \\
\text { licher Forschung gehört, dass nicht alle wissen- } \\
\text { schaftlichen Zielsetzungen erreicht werden. }\end{array}$ & $\begin{array}{l}\text { Anzahl der weltweiten Publikationen } \\
\text { zum Thema Gentherapie (GT-03) } \\
\text { Anzahl der wissenschaftlichen Einrich- } \\
\text { tungen und Forschungsgruppen im } \\
\text { Bereich der Gentherapie (GT-04) } \\
\text { Anzahl der klinischen Studien zur Gen- } \\
\text { therapie (GT-07) } \\
\text { genutzte Vektoren in klinischen Studien } \\
\text { zur Gentherapie (GT-09) }\end{array}$ \\
\hline $\begin{array}{l}\text { Reflexion über } \\
\text { die Entwicklung } \\
\text { des Feldes }\end{array}$ & $\begin{array}{l}\text { Die Entwicklung der gentherapeutischen } \\
\text { Forschung mit ihren Erfolgsgeschichten und } \\
\text { Rückschlägen prägt wesentlich das (Selbst-) } \\
\text { Verständnis der Disziplin. }\end{array}$ & Selbstkritische Äußerungen zum Thema \\
\hline
\end{tabular}




\begin{tabular}{|c|c|c|}
\hline Problemfeld & These & Indikatoren") \\
\hline \multicolumn{3}{|c|}{ Wissenschaftliche Dimension $<>$ Ethische Dimension } \\
\hline $\begin{array}{l}\text { forschungsethi- } \\
\text { sche Implika- } \\
\text { tionen }\end{array}$ & $\begin{array}{l}\text { Die Forschung an Menschen ist höchst } \\
\text { problematisch und unterliegt deshalb strengen } \\
\text { Standards und Kontrollen. Innerhalb genthe- } \\
\text { rapeutischer Forschung wird eine Vielzahl von } \\
\text { forschungsethischen Fragen relevant, da es } \\
\text { sich hier zurzeit noch um eine sehr risikobe- } \\
\text { haftete Technik handelt, mit Teil irreversiblen } \\
\text { Konsequenzen. }\end{array}$ & $\begin{array}{l}\text { publizistische Auseinandersetzung mit dem } \\
\text { Thema (Fachzeitschriften, überregionale } \\
\text { Presse, nach Fachgebieten) } \\
\text { Art und Zahl der Auflagen für die Zulassung } \\
\text { gentherapeutischer Forschung beziehungswei- } \\
\text { se Anwendung }\end{array}$ \\
\hline $\begin{array}{l}\text { Realisierung } \\
\text { medizinischer } \\
\text { Zielsetzungen }\end{array}$ & $\begin{array}{l}\text { Ziel gentherapeutischer Forschung und } \\
\text { Anwendung liegt in der Verbesserung / } \\
\text { Steigerung der Lebensqualität / Lebenserwar- } \\
\text { tung einzelner Patientinnen und Patienten, wo } \\
\text { alternative Therapieansätze fehlen oder wenig } \\
\text { effizient sind. }\end{array}$ & $\begin{array}{l}\text { Anzahl der klinischen Studien zur Gen- } \\
\text { therapie (GT-07) } \\
\text { Verteilung der Indikationen bei klini- } \\
\text { schen Studien zur Gentherapie (GT-08) } \\
\text { Anzahl der Patentanmeldungen im } \\
\text { Bereich der Gentherapie in Deutschland } \\
\text { (GT-11) } \\
\text { Zahl der erfolgreich therapierten Patienten } \\
\text { (nach Indikationen) } \\
\text { Wirksamkeit von gentherapeutischen Ansätzen } \\
\text { im Vergleich zu alternativen Behandlungsver- } \\
\text { fahren (hinsichtlich Heilungserfolgen, schweren } \\
\text { Nebenwirkungen; nach Indikationen) }\end{array}$ \\
\hline $\begin{array}{l}\text { therapeutische } \\
\text { Alternativen }\end{array}$ & $\begin{array}{l}\text { Zum Wohle der Patientinnen und Patienten } \\
\text { muss stets der Vergleich mit anderen Thera- } \\
\text { pieansätzen hinsichtlich Qualität, Wirtschaft- } \\
\text { lichkeit und ethischen Fragestellungen gesucht } \\
\text { und entsprechend abgewogen werden. }\end{array}$ & $\begin{array}{l}\text { Verteilung möglicher Therapieansätze hinsicht- } \\
\text { lich Gentherapie (nach Indikationen) } \\
\text { Wirksamkeit von gentherapeutischen Ansätzen } \\
\text { im Vergleich zu alternativen Behandlungs- } \\
\text { verfahren (hinsichtlich Heilungserfolgen, } \\
\text { Todesraten; nach Indikationen) } \\
\text { Kosten von Gentherapieverfahren im Vergleich } \\
\text { zu alternativen Behandlungsverfahren (nach } \\
\text { Indikationen) } \\
\text { Verteilung von Forschungsgeldern für verschie- } \\
\text { dene Therapieansätze (inkl. Gentherapie; nach } \\
\text { Indikationen) }\end{array}$ \\
\hline $\begin{array}{l}\text { therapeutische } \\
\text { Risiken }\end{array}$ & $\begin{array}{l}\text { Gentherapeutika besitzen ein hohes Risiko- } \\
\text { potenzial; deshalb sind die therapeutischen } \\
\text { Risiken jeweils vor dem Hintergrund individu- } \\
\text { eller Krankheitsbilder und Lebenserwartungen } \\
\text { abzuwägen. }\end{array}$ & $\begin{array}{l}\text { Wirksamkeit von gentherapeutischen Ansätzen } \\
\text { im Vergleich zu alternativen Behandlungsver- } \\
\text { fahren (hinsichtlich Heilungserfolgen, schweren } \\
\text { Nebenwirkungen; nach Indikationen) }\end{array}$ \\
\hline
\end{tabular}




\begin{tabular}{|c|c|c|}
\hline Problemfeld & These & Indikatoren") \\
\hline \multicolumn{3}{|c|}{ Wissenschaftliche Dimension <> Ökonomische Dimension } \\
\hline $\begin{array}{l}\text { Forschungs- } \\
\text { standort } \\
\text { Deutschland }\end{array}$ & $\begin{array}{l}\text { Für ein an Rohstoffen armes Land ist eine } \\
\text { wissensbasierte Ökonomie von zentraler } \\
\text { Bedeutung für die wirtschaftliche Prosperität } \\
\text { und den gesellschaftlichen Wohlstand. }\end{array}$ & $\begin{array}{l}\text { Anzahl der weltweiten Publikationen } \\
\text { zum Thema Gentherapie (GT-03) } \\
\text { Anzahl der wissenschaftlichen Einrich- } \\
\text { tungen und Forschungsgruppen im } \\
\text { Bereich der Gentherapie (GT-04) } \\
\text { Höhe der öffentlichen Förderung für } \\
\text { Gentherapie in Deutschland (GT-05) } \\
\text { Höhe der Förderung von EU-Projekten } \\
\text { im Bereich der Gentherapie mit deut- } \\
\text { scher Beteiligung (GT-06) } \\
\text { Anzahl der klinischen Studien zur Gen- } \\
\text { therapie (GT-07) } \\
\text { Verteilung der Indikationen bei klini- } \\
\text { schen Studien zur Gentherapie (GT-08) } \\
\text { Genutzte Vektoren in klinischen Studien } \\
\text { zur Gentherapie (GT-09) } \\
\text { Anzahl der Anträge auf klinische Prü- } \\
\text { fungen im Bereich der Gentherapie in } \\
\text { Deutschland (nach Phasen) (GT-10) } \\
\text { Anzahl der Patentanmeldungen im } \\
\text { Bereich der Gentherapie in Deutschland } \\
\text { (GT-11) } \\
\text { Anzahl der auf dem Gebiet der Genthe- } \\
\text { rapie arbeitenden Firmen in Deutsch- } \\
\text { land (GT-12) } \\
\text { Anzahl der kommerziell Beschäftigten } \\
\text { im Bereich der Gentherapie in Deutsch- } \\
\text { land (GT-13) } \\
\text { Dissertationen zum Thema Gentherapie } \\
\text { (GT-17)* } \\
\text { Teilnehmende der fachgesellschaftli- } \\
\text { chen Jahrestagungen (GT-20)* } \\
\text { Anzahl der abgelehnten Studien zur Genthera- } \\
\text { pie in Deutschland } \\
\text { Anzahl der erteilten EU-Patente im Bereich } \\
\text { Gentherapie/Anteil aus Deutschland } \\
\text { Anzahl der offenen Stellen im Bereich For- } \\
\text { schung und Entwicklung }\end{array}$ \\
\hline
\end{tabular}




\begin{tabular}{|c|c|c|}
\hline Problemfeld & These & Indikatoren") \\
\hline $\begin{array}{l}\text { Transfer in } \\
\text { Produkte }\end{array}$ & $\begin{array}{l}\text { Nicht in allen Wissenschaftsgebieten werden } \\
\text { Forschungsergebnisse gleichermaßen effizient } \\
\text { in neue Produkte überführt. Gleichzeitig führt } \\
\text { der Druck zur ökonomischen Verwertung von } \\
\text { Forschungsergebnissen gegebenenfalls zu } \\
\text { verfrühten, nicht haltbaren Versprechungen. }\end{array}$ & $\begin{array}{l}\text { Anzahl der klinischen Studien zur Gen- } \\
\text { therapie (GT-07) } \\
\text { Anzahl der Anträge auf klinische Prü- } \\
\text { fungen im Bereich der Gentherapie in } \\
\text { Deutschland (GT-10) } \\
\text { Anzahl der Patentanmeldungen im } \\
\text { Bereich der Gentherapie in Deutschland } \\
\text { (GT-11) } \\
\text { Anzahl der auf dem Gebiet der Genthe- } \\
\text { rapie arbeitenden Firmen in Deutsch- } \\
\text { land (GT-12) } \\
\text { Anzahl der kommerziellen und nichtkommerzi- } \\
\text { ellen Anbieter von Vektoren in der EU (GT-14) } \\
\text { Anzahl der zugelassenen Produkte/Therapien } \\
\text { in Deutschland beziehungsweise weltweit }\end{array}$ \\
\hline \multicolumn{3}{|c|}{ Ethische Dimension $<>$ Soziale Dimension } \\
\hline $\begin{array}{l}\text { Eingriff in die } \\
\text { menschliche } \\
\text { Keimbahn }\end{array}$ & $\begin{array}{l}\text { Die technische Möglichkeit eines Gentransfers } \\
\text { eröffnet prinzipiell auch den verändernden } \\
\text { Eingriff in die Keimbahn des Menschen. Damit } \\
\text { wird eine generationenübergreifende Verände- } \\
\text { rung des menschlichen Erbgutes möglich. }\end{array}$ & $\begin{array}{l}\text { publizistische Auseinandersetzung mit dem } \\
\text { Thema (Fachzeitschriften, überregionale } \\
\text { Presse, nach Fachgebieten) }\end{array}$ \\
\hline $\begin{array}{l}\text { Anwendung } \\
\text { eines Gentrans- } \\
\text { fers im nicht- } \\
\text { therapeutischen } \\
\text { Bereich }\end{array}$ & $\begin{array}{l}\text { Die technische Möglichkeit eines Gentrans- } \\
\text { fers eröffnet prinzipiell auch die Nutzung für } \\
\text { nichttherapeutische Eingriffe (sog. Enhance- } \\
\text { ment-Maßnahmen). In diesem Zusammenhang } \\
\text { werden auch Missbrauchsszenarien relevant. }\end{array}$ & $\begin{array}{l}\text { publizistische Auseinandersetzung mit dem } \\
\text { Thema (Fachzeitschriften, überregionale } \\
\text { Presse, nach Fachgebieten) } \\
\text { Verhältnismäßigkeit von therapeutischen und } \\
\text { verbessernden Eingriffen via Gentransfer (nach } \\
\text { Literaturlage) }\end{array}$ \\
\hline
\end{tabular}

1) Nicht für alle Problemfelder lassen sich Indikatoren finden, die es ermöglichen, das definierte Problemfeld quantitativ zu erfassen. Falls ein Ausmessen eines der Problemfelder mittels Indikatoren nicht möglich ist oder nicht die zu erfordernde Präzisierung erbringt, muss auf qualitative Beschreibungen zurückgegriffen werden. Die fett markierten Indikatoren werden nachfolgend anhand detaillierter Datenblätter vorgestellt und grafisch aufbereitet; ${ }^{*}$ kennzeichnet neue Indikatoren im Vergleich zur letzten Veröffentlichung der Daten (vgl. Domasch/Osterheider, 2011:257-301).

Ein Großteil der nachfolgenden Indikatoren werden seit 2008 (erstmalige Beschäftigung, Hucho et al., 2008:167-184) fortgeschrieben: So lassen sich über das langfristige Monitoring folgende Problemfelder besonders gut beobachten (im Einzelnen siehe unten):

- Forschungsstandort Deutschland

- Transfer in Produkte

- Realisierung wissenschaftlicher Zielsetzungen

- Realisierung medizinischer Zielsetzungen 
Darüber hinaus werden beständig neue Indikatoren recherchiert und geprüft, sodass sich die Zahl entsprechender Kenngrößen - idealerweise - vergrößert: In unserem Zusammenhang werden hier erstmals sechs neue Indikatoren (GT-15 bis GT-20) beschrieben; sie füllen die Problemfelder öffentliche Wahrnehmung sowie den Forschungsstandort Deutschland weiter mit belastbaren Zahlen:

- Anzahl der verfügbaren Bücher zum Thema Gentherapie (GT-15)

- Neuerscheinungen zum Thema Gentherapie (GT-16)

- Dissertationen zum Thema Gentherapie (GT-17)

- Internetpräsenz zum Thema Gentherapie (GT-18)

- Mediale Präsenz zum Thema Gentherapie (GT-19)

- Teilnehmende der fachgesellschaftlichen Jahrestagungen (GT-20)

Im nachteiligen Fall können nicht alle bestehenden Indikatoren fortgeschrieben werden: Hier existieren entweder zurzeit keine neuen Daten wie z. B. für die Bewertung der Gentherapie in Deutschland (siehe GT-01) oder den Grad der Unterstützung der Gentherapie in Deutschland (siehe GT-02); solche Daten werden gleichwohl weiterhin gelistet und als Indikatoren dargestellt. Im anderen Fall ist eine kontinuierliche Fortschreibung prinzipiell nicht mehr möglich (einmalige Daten, geänderte Dokumentationsform etc.); solche Indikatoren werden weiterhin gelistet, aber nicht mehr als Daten veröffentlicht. Für unseren Fall betrifft dies (nur) die Anzahl der kommerziellen und nichtkommerziellen Anbieter von Vektoren in der EU (siehe GT-14).

\subsubsection{Daten zu öffentlicher Wahrnehmung, Forschungsstandort Deutschland, Transfer in Produkte sowie Realisierung wissenschaftlicher und medizinischer Zielsetzungen}

Mittels standardisierter Datenblätter werden folgende Indikatoren nachfolgend vorgestellt. Ein Großteil der hier präsentierten Daten kann dabei als Fortschreibung der seit 2008 veröffentlichten Zahlen gesehen werden (vgl. u. a. Müller-Röber et al., 2009:205235; Domasch/Osterheider, 2011:266-300). Die Rubriken „Abgrenzung der Berechnungsgrößen“ und „Aussagefähigkeit“ bilden wie immer den interpretativen Rahmen.

Öffentliche Wahrnehmung

- Bewertung der Gentherapie in Deutschland (GT-01)

- Grad der Unterstützung der Gentherapie (GT-02)

- Anzahl der verfügbaren Bücher zum Thema Gentherapie (GT-15)

- Neuerscheinungen zum Thema Gentherapia (GT-16) 
- Internetpräsenz zum Thema Gentherapie (GT-18)

- Mediale Präsenz zum Thema Gentherapie (GT-19)

Forschungsstandort Deutschland

- Anzahl der weltweiten Publikationen zum Thema Gentherapie (GT-03)

- Anzahl der wissenschaftlichen Einrichtungen und Forschungsgruppen im Bereich der Gentherapie (GT-04)

- Höhe der öffentlichen Förderung für Gentherapie in Deutschland (GT-05)

- Höhe der Förderung von EU-Projekten im Bereich der Gentherapie mit deutscher Beteiligung (GT-06)

- Anzahl der klinischen Studien zur Gentherapie (GT-07)

- Verteilung der Indikationen bei klinischen Studien zur Gentherapie (GT-08)

- Genutzte Vektoren in klinischen Studien zur Gentherapie (GT-09)

- Anzahl der Anträge auf klinische Prüfungen im Bereich der Gentherapie in Deutschland (GT-10)

- Anzahl der Patentanmeldungen im Bereich der Gentherapie in Deutschland (GT-11)

- Anzahl der auf dem Gebiet der Gentherapie arbeitenden Firmen in Deutschland (GT12)

- Anzahl der kommerziell Beschäftigten im Bereich der Gentherapie in Deutschland (GT-13)

- Dissertationen zum Thema Gentherapie (GT-17)

- Teilnehmende der fachgesellschaftlichen Jahrestagungen (GT-20)

Transfer in Produkte

- Anzahl der klinischen Studien zur Gentherapie (GT-07)

- Anzahl der Anträge auf klinische Prüfungen im Bereich der Gentherapie in Deutschland (GT-10)

- Anzahl der Patentanmeldungen im Bereich der Gentherapie in Deutschland (GT-11)

- Anzahl der auf dem Gebiet der Gentherapie arbeitenden Firmen in Deutschland (GT-12)

Realisierung medizinischer Zielsetzungen

- Anzahl der klinischen Studien zur Gentherapie (GT-07)

- Verteilung der Indikationen bei klinischen Studien zur Gentherapie (GT-08) 
Realisierung wissenschaftlicher Zielsetzungen

- Anzahl der weltweiten Publikationen zum Thema Gentherapie (GT-03)

- Anzahl der wissenschaftlichen Einrichtungen und Forschungsgruppen im Bereich der Gentherapie (GT-04)

- Anzahl der klinischen Studien zur Gentherapie (GT-07)

- Genutzte Vektoren in klinischen Studien zur Gentherapie (GT-09) 
Laufende Nr:: GT-01

Problemfeld: Öffentliche Wahrnehmung

\section{INDIKATOR: BEWERTUNG DER GENTHERAPIE IN DEUTSCHLAND}

\section{DATENQUELLE:}

Eurobarometer 64.3 - Europeans and Biotechnology in 2005: Patterns and Trends. Unter: http://sec.europa.eu/research/press/2006/pdf/pr1906_eb_64_3_final_report-may2006_en.pdf Zugriff: Januar 2009, Stand der Daten: Mai 2006.

\section{VERFÜGBARKEIT DER DATEN:}

öffentlich

\section{ABGRENZUNG DER BERECHNUNGSGRÖSSEN:}

Als Grundlage für diesen Indikator dienen die Daten des Eurobarometers 64.3 aus dem Jahre 2005. Die Einstellungen der europäischen Bevölkerung zur Gentechnik waren bereits Gegenstand der Erhebungen der Jahre 1991, 1993, 1996, 1999 und 2002; Fragen hinsichtlich der Gentherapie wurden erstmals 2005 gestellt. Die Erhebungen des Eurobarometers 64.3. wurden in allen 25 Mitgliedsstaaten durchgeführt; pro Land wurden rund 1000 Personen befragt.

Neuere Daten werden frühestens 2015 erwartet, da für 2014 die nächste Eurobarometer-Umfrage zur Biotechnologie geplant ist. Aus Gründen der Transparenz werden die Daten von 2005 hier nochmals veröffentlicht.

\section{GLIEDERUNG DER DARSTELLUNG:}

siehe Abbildung

\section{BERECHNUNGSHÄUFIGKEIT:}

einmalig, ggf. Fortschreibung 2015

\section{AUSSAGEFÄHIGKEIT:}

Im Rahmen der Eurobarometer-Befragung wurde nicht nur die Zustimmung und Ablehnung zur Gentherapie erfragt, sondern es wurden auch Fragen nach der Nutzen- und Risikowahrnehmung sowie nach der Einschätzung der ethischen Akzeptabilität gestellt. Dahinter steht die Idee, dass die Einstellung zur Gentherapie die Folge eines Bewertungs- und Abwägungsprozesses zwischen verschiedenen Bewertungsdimensionen ist, die zu einem Gesamturteil aggregiert werden.

Abbildung 2: Bewertung der Gentherapie in Deutschland

$40 \%$

$35 \%$

$30 \%$

$25 \%$

$20 \%$

$15 \%$

$10 \%$

$5 \%$
34,1

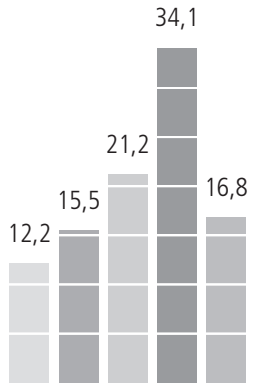

ethisch akzeptabel

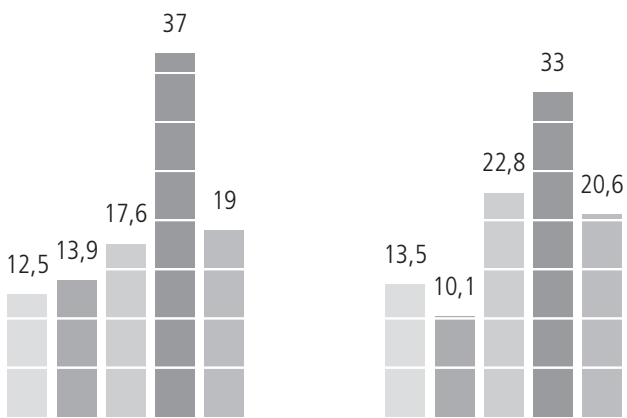

nützlich

riskant weiß nicht lehne voll und ganz ab Quelle: siehe Indikatorenblatt GT-01 lehne sher ab

stimme eher $z$ u stimme voll und ganz zu 
Laufende Nr.: GT-02

Problemfeld: Öffentliche Wahrnehmung

\section{INDIKATOR: GRAD DER UNTERSTÜTZUNG DER GENTHERAPIE}

\section{DATENQUELLE:}

Eurobarometer 64.3 - Europeans and Biotechnology in 2005: Patterns and Trends. Unter: http://sec.europa.eu/research/press/2006/pdf/pr1906_eb_64_3_final_report-may2006_en.pdf Zugriff: Januar 2009, Stand der Daten: Mai 2006.

Eurobarometer 73.1 - Europeans and Biotechnology in 2010: Winds of Change? Unter: http://ec.europa.eu/research/science-society/document_library/pdf_06/europeans-biotechnology-in-2010_en.pdf Zugriff: Juli 2011, Stand der Daten: Oktober 2010.

\section{VERFÜGBARKEIT DER DATEN:}

öffentlich

\section{ABGRENZUNG DER BERECHNUNGSGRÖSSEN:}

Als Grundlage für diesen Indikator dienen die Daten der Eurobarometer 64.3 aus dem Jahre 2005 und dem Eurobarometer 73.1 aus dem Jahr 2010. Die Einstellungen der europäischen Bevölkerung zur Gentechnik waren bereits Gegenstand der Erhebungen der Jahre 1991, 1993, 1996, 1999 und 2002; Fragen hinsichtlich der Gentherapie wurden erstmals 2005 gestellt. Die Erhebungen des Eurobarometers 64.3. wurden in allen 25 Mitgliedsstaaten durchgeführt, das Eurobarometer 73.1 in 27 Mitgliedsstaaten; pro Land wurden rund 1000 Personen befragt.

Neuere Daten werden frühestens 2015 erwartet, da für 2014 die nächste Eurobarometer-Umfrage zur Biotechnologie geplant ist. Aus Gründen der Transparenz werden die Daten von 2005 und 2010 hier nochmals veröffentlicht.

\section{GLIEDERUNG DER DARSTELLUNG:}

a) in Deutschland und der EU

b) in Deutschland (in Abhängigkeit vom Regulierungskontext)

\section{BERECHNUNGSHÄUFIGKEIT:}

zweimalig, ggf. Fortschreibung 2015

\section{AUSSAGEFÄHIGKEIT:}

Wiedergegeben wird die geäußerte Unterstützung der Gentherapie in Deutschland und Europa. Im Rahmen des Eurobarometers 64.3 sollten die Befragten angeben, ob sie der Aussage, dass die Gentherapie - als Behandlung von Krankheiten durch genetische Eingriffe - unterstützt werden sollte, zustimmen oder nicht. Ziel dieser Fragestellung war es herauszufinden, ob die Befragten der Gentherapie eher positiv oder negativ gegenüber stehen. Im Rahmen der Eurobarometer 64.2 und 73.1 wurde der Grad der Unterstützung in Abhängigkeit vom Regulierungskontext abgefragt. In Zukunft gilt zu beobachten, wie sich die Unterstützung in Anbetracht der medizinischen Fortschritte auf dem Gebiet der Gentherapie entwickeln wird. 
a) Abbildung 3: Unterstützung der Gentherapie in Deutschland und Europa (2005)

$40 \%$

$35 \%$

$30 \%$

$25 \%$

$20 \%$

$15 \%$

$10 \%$

$5 \%$

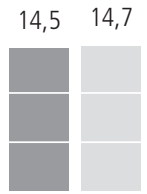

voll und ganz

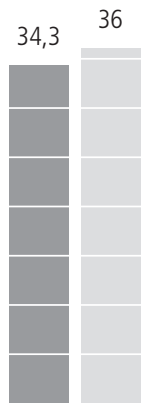

eher ja

36

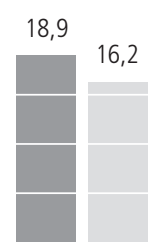

eher nicht
Deutschland EU

23,8

19,3

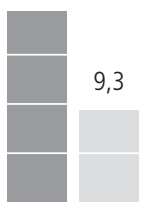

13,1

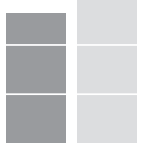

weiß nicht

Quelle: siehe Indikatorenblatt GT-02.

b) Abbildung 4: Grad der Unterstützung der Gentherapie in Deutschland (in Abhängigkeit vom Regulierungskontext)

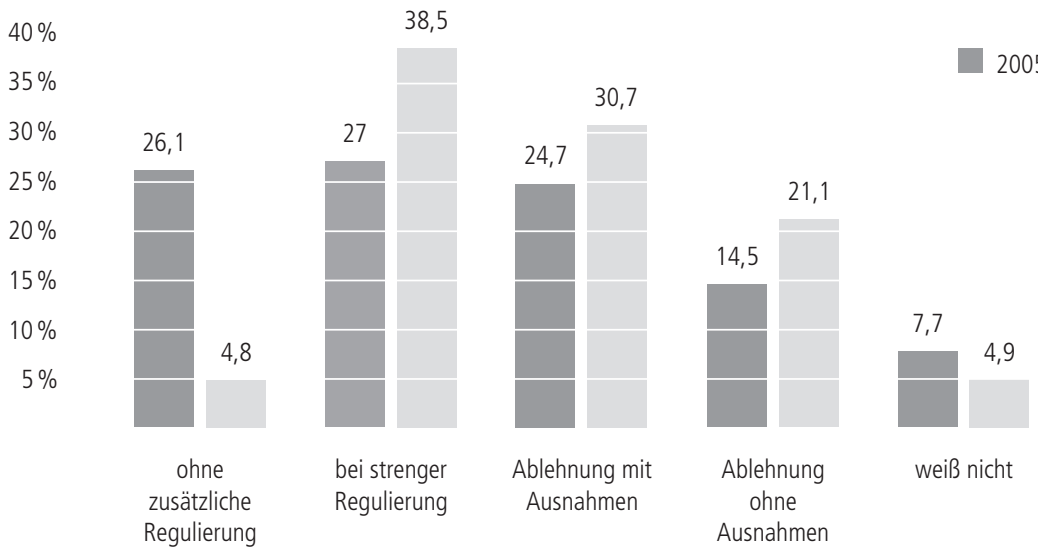

Quelle: siehe Indikatorenblatt GT-02. 
Laufende Nr.: GT-03

Problemfeld: Forschungsstandort Deutschland + Realisierung wissenschaftlicher Zielsetzungen

\section{INDIKATOR: ANZAHL DER WELTWEITEN PUBLIKATIONEN ZUM THEMA GENTHERAPIE}

\section{DATENQUELLE:}

Scopus - Literaturdatenbank. Unter:

www.scopus.com

Zugriff: Mai 2013, Stand der Daten: Mai 2013.

\section{VERFÜGBARKEIT DER DATEN:}

Die Datenbank bietet eine Sammlung an Abstracts, Quellenverweisen und Stichwortverzeichnissen im Bereich der Natur- und Ingenieurwissenschaften, in Medizin und Sozialwissenschaften. Die Nutzung der Datenbank Scopus ist kostenpflichtig und wird nach eigenen Angaben täglich aktualisiert.

\section{ABGRENZUNG DER BERECHNUNGSGRÖSSEN:}

Durchgeführt wurde die Suche anhand der Stichworte "gene therapy AND vector" nach "articles" in "all fields", nach Ländern und Jahren.

\section{GLIEDERUNG DER DARSTELLUNG:}

a) internationale Publikationsleistungen nach Jahren;

b) nationale Publikationsleistungen im europäischen Vergleich;

c) Wachstumsraten Deutschland im Vergleich zu EU gesamt;

d) nationale Publikationsleistungen im internationalen Bereich

\section{BERECHNUNGSHÄUFIGKEIT:}

jährlich

\section{AUSSAGEFÄHIGKEIT:}

Der Indikator spiegelt die weltweiten naturwissenschaftlich-medizinischen Forschungsaktivitäten im Gebiet der Gentherapie wider und ermöglicht einen Vergleich zwischen den Ländern beziehungsweise Regionen. Entsprechend kann beobachtet werden, welche Länder beziehungsweise Regionen eine Vorrangstellung im „internationalen Forschungswettlauf" einnehmen und ob sich Positionen im Zeitverlauf verändern.

Bei der Anzahl der Publikationen handelt es sich um einen klassischen Frühindikator, der zwar sensibel für Entwicklungstrends ist, Entwicklungen jedoch rein quantitativ bemisst. Er erlaubt somit keine Aussagen darüber, welchen Reifegrad eine wissenschaftlich-technische Entwicklung besitzt. Anders als die öffentliche Berichterstattung erlaubt er - abseits von Schlagzeilen - einen verlässlichen Blick darauf, in welchem Maße Forschungen zur Gentherapie weltweit verfolgt werden.

Für die nationalen Publikationsleistungen im internationalen Vergleich wurde sich auf die drei führenden Nationen USA, China und Deutschland (!) beschränkt; Großbritannien nimmt im internationalen Vergleich Rang vier ein (539 in 2012). Weitere, nicht europäische aber publikationsstarke Staaten wie Kanada (353 in 2012), Südkorea (308 in 2012) oder Australien (189 in 2012) reihen sich zwischen anderen europäischen Staaten (siehe Tabelle 3) ein. 
a) Abbildung 5: Internationale Publikationsleistungen zum Thema Gentherapie (nach Jahren)

2012

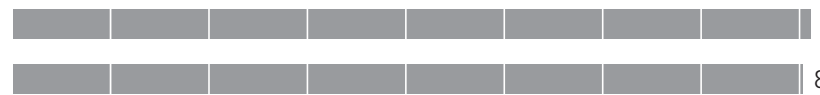

2011

7136

2010

6756

2009

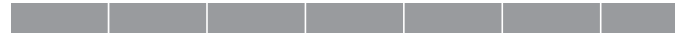

2008

6261

2007

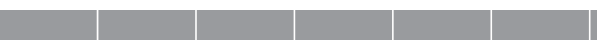

6067

2006

5859

2005

5382

2004

5030

2003

4536

2002

4303

2001

3974

2000

3710

1999

3111

1998

2532

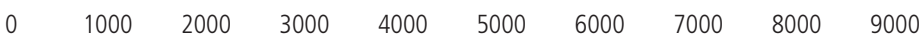

Jeweils aktualisierte Daten; Unterschiede zu früheren Veröffentlichungen möglich. Quelle: siehe Indikatorenblatt GT-03.

b) Tabelle 3: Nationale Publikationsleistungen im europäischen Vergleich

\begin{tabular}{|c|c|c|c|c|c|c|c|c|c|}
\hline Jahr & Deutschland & U.K. & Frankreich & Italien & Niederlande & Schweiz & Schweden & Belgien & EU gesamt* \\
\hline 1998 & 198 & 208 & 205 & 95 & 73 & 63 & 27 & 33 & 902 \\
\hline 1999 & 246 & 239 & 246 & 104 & 70 & 85 & 47 & 45 & 1082 \\
\hline 2000 & 316 & 284 & 282 & 146 & 91 & 116 & 42 & 56 & 1333 \\
\hline 2001 & 358 & 273 & 238 & 133 & 94 & 103 & 54 & 43 & 1296 \\
\hline 2002 & 350 & 262 & 255 & 131 & 126 & 86 & 74 & 61 & 1345 \\
\hline 2003 & 431 & 336 & 270 & 143 & 131 & 90 & 74 & 51 & 1526 \\
\hline 2004 & 450 & 379 & 289 & 171 & 141 & 128 & 83 & 51 & 1692 \\
\hline 2005 & 486 & 372 & 301 & 206 & 153 & 123 & 86 & 61 & 1788 \\
\hline 2006 & 503 & 392 & 317 & 194 & 200 & 137 & 86 & 73 & 1902 \\
\hline 2007 & 501 & 383 & 306 & 221 & 195 & 121 & 101 & 89 & 1917 \\
\hline 2008 & 517 & 410 & 306 & 250 & 154 & 141 & 83 & 100 & 1961 \\
\hline 2009 & 573 & 463 & 385 & 252 & 144 & 139 & 105 & 92 & 2153 \\
\hline 2010 & 601 & 460 & 327 & 256 & 187 & 133 & 111 & 107 & 2182 \\
\hline 2011 & 689 & 547 & 361 & 315 & 209 & 182 & 122 & 96 & 2521 \\
\hline 2012 & 724 & 539 & 375 & 311 & 194 & 180 & 126 & 118 & 2567 \\
\hline
\end{tabular}

* Fasst die Daten aus den acht europäischen Ländern zusammen; jeweils aktualisierte Daten; Unterschiede zu früheren Veröffentlichungen möglich. Quelle: siehedndikatorenblatt $\leqq J-0.3 .956-210$, am 26.04.2023, 13:17:31 
c) Abbildung 6: Wachstumsrate Deutschland im Vergleich zu EU gesamt (im Verhältnis zum Basisjahr 1998, in Prozent)

$$
\begin{array}{r}
300 \\
250 \\
200 \\
150 \\
100 \\
50 \\
0
\end{array}
$$

\begin{tabular}{|c|c|c|c|c|c|c|c|c|c|c|c|c|c|c|}
\hline & 1999 & 2000 & 2001 & 2002 & 2003 & 2004 & 2005 & 2006 & 2007 & 2008 & 2009 & 2010 & 2011 & 2012 \\
\hline \multicolumn{15}{|c|}{ Deutschland } \\
\hline & 24,2 & 59,6 & 80,8 & 76,8 & 117,7 & 127,3 & 145,5 & 154,0 & 153,0 & 161,1 & 189,4 & 203,5 & 248,0 & 265,7 \\
\hline \multicolumn{15}{|c|}{ EU gesamt } \\
\hline & 20,0 & 47,8 & 43,7 & 49,1 & 69,2 & 87,6 & 98,2 & 110,9 & 112,5 & 117,4 & 138,7 & 141,9 & 179,5 & 184,6 \\
\hline
\end{tabular}

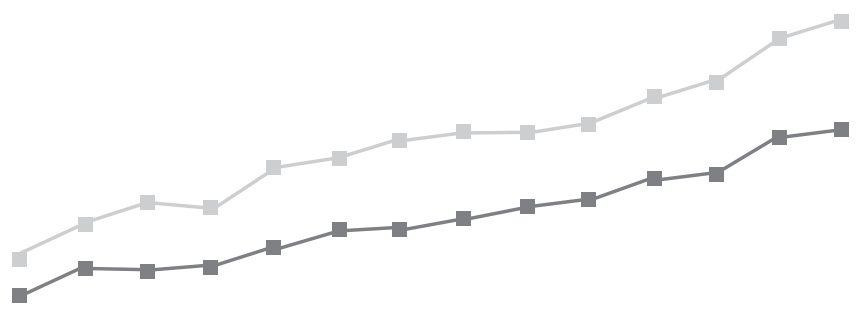

199819992000200120022003200420052006200720082009201020112012

Quelle: siehe Indikatorenblatt GT-03.

d) Abbildung 7: Nationale Publikationsleistung im internationalen Vergleich

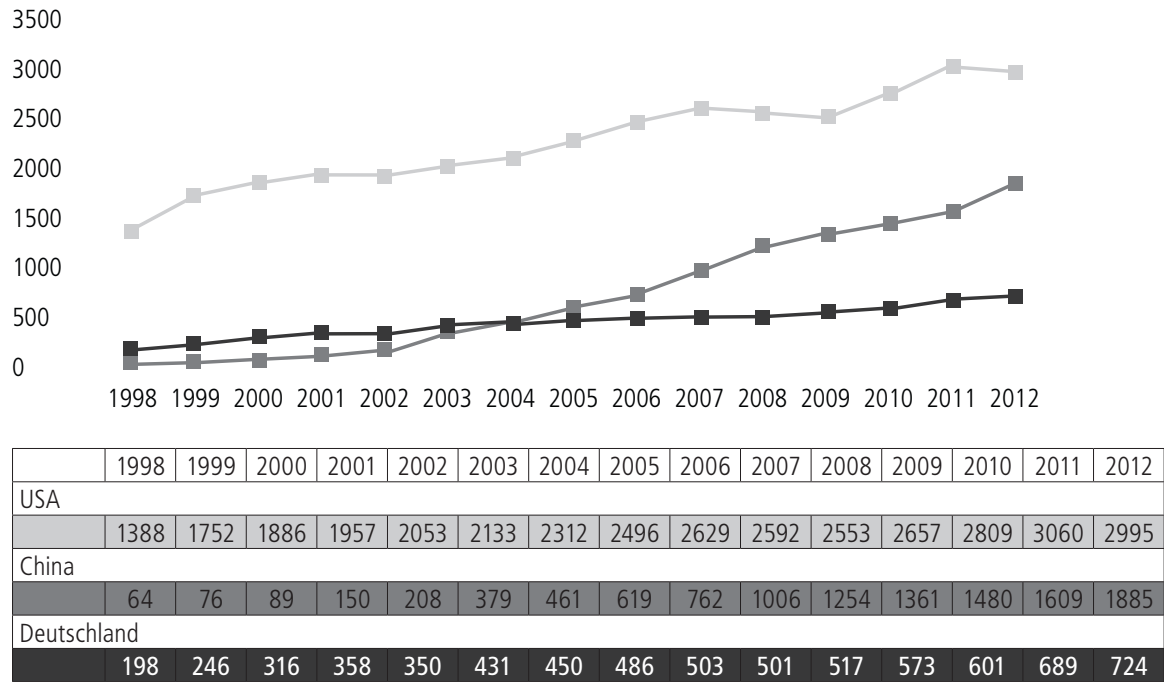

Jeweils aktualisierte Daten; Unterschiede zu früheren Veröffentlichungen möglich. Quelle: siehe Indikatorenblatt GT-03. 
Laufende Nr.: GT-04

Problemfeld: Forschungsstandort Deutschland + Realisierung wissenschaftlicher Zielsetzungen

\section{INDIKATOR: ANZAHL DER WISSENSCHAFTLICHEN EINRICHTUNGEN UND FORSCHUNGSGRUPPEN IM BEREICH DER GENTHERAPIE}

\section{DATENQUELLE:}

Erhebung im Auftrag des Bundesministeriums für Bildung und Forschung (BMBF),

Informationsplattform Biotechnologie.de, Datenbank unter:

www.biotechnologie.de/BIO/Navigation/DE/Datenbank/biotechnologie-db.html?

Biotechnologie-Branchenumfrage 2007 (für Stichtag 31.12.2006): Zugriff: April 2008, Stand der Daten: Dezember 2006.

Biotechnologie-Branchenumfrage 2009 (für Stichtag 31.12.2008): Zugriff: Mai 2011, Stand der Daten: Dezember 2008.

Biotechnologie-Branchenumfrage 2011 (für Stichtag 31.12.2010): Zugriff: Juni 2011, Stand der Daten: Dezember 2010.

Biotechnologie-Branchenumfrage 2013 (für Stichtag 31.12.2012): Zugriff: Juli 2013, Stand der Daten: Dezember 2012.

\section{VERFÜGBARKEIT DER DATEN:}

öffentlich

\section{ABGRENZUNG DER BERECHNUNGSGRÖSSEN:}

Die Daten wurden nach den Leitlinien der Organisation für wirtschaftliche Zusammenarbeit und Entwicklung (OECD) erhoben. Berücksichtigt werden Institutionen, die nach der OECD-Definiton im Bereich der „DNA- und/der RNA-Vektoren" (Gentherapie, Virale Vektoren, früher "Subzelluläre Organismen") tätig sind und deren Ausrichtung Gesundheit/ Medizin (d. h. Entwicklung von Therapeutika und/oder Diagnostika für den human-medizinischen Bereich, Drug Delivery, Gewebe-Ersatz) und nicht-spezifische Anwendungen (d. h. auf biotechnologischen Prinzipien basierende Geräte und Reagenzien für die Forschung sowie Dienstleistungen in diesem Bereich) umfassen.

Die Zahlen dokumentieren den Stand des 1. Januar des genannten Jahres und verweisen auf das jeweilige Vorjahr (siehe Datenquelle); um einheitliche Veröffentlichungslogiken zu bisherigen Publikationen zu gewährleisten, wird die bisher genutzte Jahreszählung beibehalten.

\section{GLIEDERUNG DER DARSTELLUNG:}

alle zwei Jahre

\section{BERECHNUNGSHÄUFIGKEIT:}

prinzipiell jährlich; Angaben werden jeweils in der Datenbank aktualisiert; ein Archiv ist nicht vorhanden bzw. öffentlich zugänglich

\section{AUSSAGEFÄHIGKEIT:}

Der Indikator erlaubt einen vertiefenden Blick auf die Forschungslandschaft im Bereich der Gentherapie und beschreibt die institutionellen Schwerpunkte bzw. deren Entwicklungen. 
Abbildung 8: Wissenschaftliche Einrichtungen/Forschungsgruppen im Bereich der Gentherapie in Deutschland

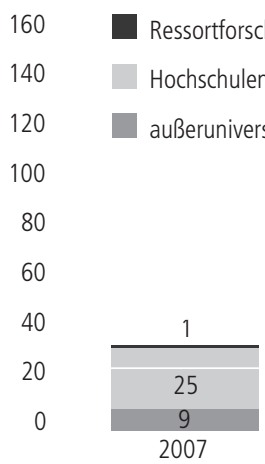

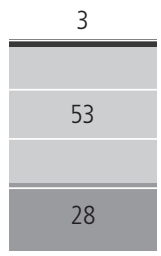

2011

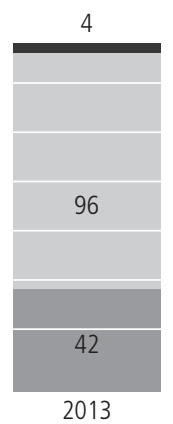

Quelle: siehe Indikatorenblatt GT-04. 
Laufende Nr.: GT-05

Problemfeld: Forschungsstandort Deutschland

\section{INDIKATOR: HÖHE DER ÖFFENTLICHEN FÖRDERUNG FÜR GENTHERAPIE IN DEUTSCHLAND}

\section{DATENQUELLE:}

Gesundheitsforschung: Forschung für den Menschen. Unter:

http://www.gesundheitsforschung-bmbf.de/de/1197.php

Zugriff: August 2013, Stand: August 2013.

Deutsche Forschungsgemeinschaft (DFG). Unter:

http://gepris.dfg.de/gepris/OCTOPUS/?null=Ihr+Suchbegriff\&nurProjekteMitAB=false\&extendButton=

Erweiterte+Suche+ausklappen\&task=doSearchSimple\&context=projekt

Zugriff: August 2013, Stand: August 2013.

\section{VERFÜGBARKEIT DER DATEN:}

öffentlich

\section{ABGRENZUNG DER BERECHNUNGSGRÖSSEN:}

Es besteht die Schwierigkeit, Forschungsaufwendungen für die Gentherapie konkret in Projekten zu identifizieren, da häufig Untersuchungen gentherapeutischer Verfahren in größere Projekte eingebettet und so nur schwer identifizierbar sind.

Genutzt wurde zum einen die Förderdatenbank des BMBF, welche die Forschungsförderung des BMBF u. a. für "Innnovative Therapieformen" listet. Es erfolgte eine Suche nach "Geförderte Projekte", die derzeit in den Förderschwerpunkten des Gesundheitsforschungsprogramms gefördert werden; unter: Individualisierte Medizin - Translationsforschung - Innovative Therapien; die Ergebnisse wurden händisch in Bezug auf gentherapeutische Forschung im engeren Sinne gegengeprüft bzw. entsprechend aussortiert. Eine "Liste der abgeschlossenen Vorhaben" ist einsehbar; diese Projekte finden hier keine Berücksichtigung:

http://www.gesundheitsforschung-bmbf.de/de/1632.php

Des Weiteren wurde die Datenbank GEPRIS der DFG genutzt, welche die geförderten Projekte der DFG listet; es erfolgte eine Stichwortsuche zu "Gentherapie" unter dem Status "laufend" + inklusive "Teilprojekte anzeigen".

\section{GLIEDERUNG DER DARSTELLUNG:}

BMBF-Programme/DFG-Projekte

\section{BERECHNUNGSHÄUFIGKEIT:}

fortlaufend

\section{AUSSAGEFÄHIGKEIT:}

Die Höhe der Forschungsförderung erlaubt Rückschlüsse auf das wissenschaftliche und wirtschaftliche Potenzial der Gentherapie, das seitens der staatlichen Ebene angenommen wird. Gerade in frühen Phasen einer technischen Innovation ist der Staat aufgefordert, finanzielle Mittel zur Generierung zukünftiger Allgemeinwohleffekte bereitzustellen, da die erforderliche Allokation von Ressourcen zum Beispiel für die Grundlagenforschung seitens der Privatwirtschaft nicht ausreichend erfolgt. Zu einem späteren Zeitpunkt, an dem die technische Innovation einen größeren Reifegrad erreicht hat und der privatwirtschaftliche Sektor unmittelbar in Forschung und Produktentwicklung investiert, sinkt die Notwendigkeit für staatliche Finanzierungen; zurückgehende Mittel wären hierbei kein Indiz für nachlassendes Interesse. Zur umfassenden Beurteilung ist eine Beobachtung über einen längeren Zeitraum erforderlich, gleichzeitig sind weitere Quellen der öffentlichen Finanzierung zu berücksichtigen. Diesbezüglich erfasst der Indikator zwar die Ausgaben des Bundes, nicht jedoch, ob und in welcher finanziellen Höhe die Bundesländer die Forschung und Entwicklung im Bereich der Gentherapie fördern. Wesentlich bedeutender sind allerdings die Förderungen seitens der EU; diese werden vom Indikator GT-06 abgebildet. 
Tabelle 4: Öffentliche Förderung für Gentherapie durch das BMBF

\begin{tabular}{|l|c|c|}
\hline BMBF, Gesundheitsforschung, Innovative Therapien & \multicolumn{1}{c|}{$\begin{array}{c}\text { Laufzeit } \\
\text { gördervolumen } \\
\text { gesamt in Euro }\end{array}$} \\
\hline Gentransferstudienregister DeReG & $01.08 .2002-31.10 .2008$ & 902.076 \\
\hline $\begin{array}{l}\text { Verbundprojekt TreatID: Behandlung schwerer Immundefekte mit } \\
\text { genmodifizierten Stammzellen (TreatID) }\end{array}$ & $01.01 .2006-31.03 .2009$ & 3.712 .077 \\
\hline $\begin{array}{l}\text { Verbundprojekt: Gen-Immuntherapie bei fortgeschrittenem Prosta- } \\
\text { takarzinom (Prostatakarzinom) }\end{array}$ & $01.10 .2006-30.09 .2009$ & 266.070 \\
\hline $\begin{array}{l}\text { Verbundprojekt: Innovative Gentherapie von Immundefizienz } \\
\text { (Immundefizienz) }\end{array}$ & $01.02 .2009-31.01 .2012$ & 1.252 .167 \\
\hline $\begin{array}{l}\text { Verbundprojekt: Innovative Zell- und Gentherapie für Morbus } \\
\text { Gaucher Typ 2 (Gaucher) }\end{array}$ & $01.03 .2009-31.05 .2012$ & 805.392 \\
\hline $\begin{array}{l}\text { Verbundprojekt: Foamyvirus Netzwerk für die Gentherapie der } \\
\text { Fanconi-Anämie (FoneFA) }\end{array}$ & $01.11 .2009-31.12 .2013$ & 1.196 .534 \\
\hline $\begin{array}{l}\text { Verbundprojekt: Entwicklung, Herstellung und präklinische Sicherheit } \\
\text { von optimierten onkolytischen Masernvirusvektoren (Maservirus- } \\
\text { vektoren) }\end{array}$ & $01.05 .2009-30.04 .2013$ & 1.212 .829 \\
\hline $\begin{array}{l}\text { Verbundprojekt: AAV-basierte Gentherapie für die therapeutische } \\
\text { Neovaskulierung bei chronisch ischämischer Herzinsuffizienz } \\
\text { (GENEVA) }\end{array}$ & $01.02 .2012-31.01 .2015$ & 1.201 .656 \\
\hline
\end{tabular}

grau = Zusammenfassung der Daten aus Domasch/Osterheider 2011:275f; abgeschlossene Projekte. Aktualisierte Daten; Unterschiede zu früheren Veröffentlichungen möglich. Quelle: siehe Indikatorenblatt GT-05. 
Tabelle 5: Laufende Projekte bei der DFG

\begin{tabular}{|c|c|c|}
\hline & seit & Anzahl $=17$ \\
\hline $\begin{array}{l}\text { Graduiertenkollegs GRK 1172: Erforschung, Entwicklung und } \\
\text { Sicherheit von Biopharmazeutika }\end{array}$ & 2005 & 1 \\
\hline Forschungsstipendien & & 2 \\
\hline (1) Gezielte nicht virale Gentherapie für Duchenne-Muskeldystrophie & 2003 & \\
\hline $\begin{array}{l}\text { (2) Molekulare und Gentherapie in Organtransplantation: Beeinflus- } \\
\text { sung von Lymphangiogenese als ein neuer Ansatz der Immunmodu- } \\
\text { lation in Herztransplantation }\end{array}$ & 2011 & \\
\hline Sachbeihilfen & & 8 \\
\hline $\begin{array}{l}\text { (1) Cytidin-Deaminase als Selektionsmarker im Rahmen der Genthe- } \\
\text { rapie hämatologischer Erkrankungen }\end{array}$ & 2012 & \\
\hline $\begin{array}{l}\text { (2) Gezielte antifibrotische Gentherapie - Stammzellpotenzial von } \\
\text { hepatischen Sternzellen }\end{array}$ & 2010 & \\
\hline $\begin{array}{l}\text { (3) Potential bakterieller Nanocellulose zur Herstellung von natürli- } \\
\text { chen, hochreinen, biokompatiblen Nanoträgern zur Gentherapie }\end{array}$ & 2011 & \\
\hline $\begin{array}{l}\text { (4) Präfabrikation myo-cutaner Weichgewebetransplantate durch } \\
\text { lokalisierte Neoangiogenese-Stimulation mittels zell-basierter VEGF- } \\
\text { Gentherapie }\end{array}$ & 2009 & \\
\hline $\begin{array}{l}\text { (5) Employing gene trapping for the correction of the Gp91phox } \\
\text { (Nox2) mutation in chronic granulomatous disease (X-CGD) }\end{array}$ & 2009 & \\
\hline $\begin{array}{l}\text { (6) Entwicklung eines Ansatzes zur Therapie neurodegenerativer } \\
\text { Erkrankungen auf Basis von RNA-Interferenz am Beispiel der } \\
\text { Prionerkrankungen }\end{array}$ & 2005 & \\
\hline $\begin{array}{l}\text { (7) Untersuchungen zur Optimierung der Neovaskularisation und der } \\
\text { Knochenregeneration in einem orthotopen Knochendefektmodell } \\
\text { durch Ko-Implantation mesenchymaler Stammzellen und humaner } \\
\text { Endothelzellen }\end{array}$ & 2005 & \\
\hline $\begin{array}{l}\text { (8) Spezifische DNA-bindende Moleküle als neue Transfektionsvek- } \\
\text { toren }\end{array}$ & 2013 & \\
\hline $\begin{array}{l}\text { (klinische) Forschergruppe KF0 134: Teilprojekt, Evaluation der } \\
\text { Wirksamkeit lokaler Gentherapie bei CNG Kanal-difizienten Maus- } \\
\text { modellen für erbliche Netzhauterkrankungen }\end{array}$ & 2008 & 1 \\
\hline $\begin{array}{l}\text { Forschergruppe FOR 1961: Mature T-cell Lymphomas - mechanisms } \\
\text { of perturbed clonal T-cell homeostasis }\end{array}$ & 2013 & 1 \\
\hline $\begin{array}{l}\text { Transregios TRR 36: Grundlagen und Anwendung adoptiver T-Zell- } \\
\text { therapie (zwei Teilprojekte) }\end{array}$ & 2006 & 2 \\
\hline $\begin{array}{l}\text { Schwerpunktprogramm SPP 1230: Mechanisms of gene vector } \\
\text { entry and persistence (inkl. ein Teilprojekt) }\end{array}$ & 2006 & 2 \\
\hline
\end{tabular}

Quelle: siehe Indikatorenblatt GT-05. 
Laufende Nr.: GT-06

Problemfeld: Forschungsstandort Deutschland

\section{INDIKATOR: HÖHE DER FÖRDERUNG VON EU-PROJEKTEN IM BEREICH DER GENTHERAPIE MIT DEUTSCHER BETEILIGUNG}

\section{DATENQUELLE:}

Sixth Framework Programme, EU-supported research in Genomics and Biotechnology for Health (2002-2006) Unter:

ftp://ftp.cordis.europa.eu/pub/lifescihealth/docs/new-therapies.pdf

Zugriff: Januar 2009, Stand der Daten: 2007.

Seventh Framework Programme (2007-2013) - Projektsuche. Unter:

http://cordis.europa.eu/fp7/projects_de.html

Zugriff: Juli 2013, Stand: k.A.

\section{VERFÜGBARKEIT DER DATEN:}

öffentlich

\section{ABGRENZUNG DER BERECHNUNGSGRÖSSEN:}

Innerhalb des 6. Forschungsrahmenprogramms wurden diejenigen Projekte zur "Gene Therapy" verzeichnet, die innerhalb der "New Therapies" gelistet wurden; dabei wurden nur jene berücksichtigt, an denen mindestens ein Akteur aus Deutschland beteiligt ist.

Die Daten zum 7. Forschungsrahmenprogramm wurden über CORDIS erhoben; es wurden alle Projekte gelistet, die mit dem Stichwort "Gene Therapy" unter der Länderberücksichtigung "Germany" verzeichnet wurden und damit mit bundesdeutscher Beteiligung sind.

\section{GLIEDERUNG DER DARSTELLUNG:}

a) Förderung von EU-Projekten mit deutscher Beteiligung nach Projekten

b) Förderung von EU-Projekten mit deutscher Beteiligung nach Laufzeiten

c) Höhe der Förderung von EU-Projekten mit deutscher Beteiligung nach Jahren

\section{BERECHNUNGSHÄUFIGKEIT:}

einmal pro Förderperiode

\section{AUSSAGEFÄHIGKEIT:}

Die Höhe der Forschungsförderung erlaubt Rückschlüsse auf das wissenschaftliche und wirtschaftliche Potenzial der Gentherapie, das seitens der EU-Ebene angenommen wird. Gerade in frühen Phasen einer technischen Innovation ist die Europäische Union aufgefordert, finanzielle Mittel zur Generierung zukünftiger Allgemeinwohleffekte bereitzustellen, da die erforderliche Allokation von Ressourcen zum Beispiel für die Grundlagenforschung seitens der Privatwirtschaft nicht ausreichend erfolgt. Zu einem späteren Zeitpunkt, an dem die technische Innovation einen größeren Reifegrad erreicht hat und der privatwirtschaftliche Sektor unmittelbar in Forschung und Produktentwicklung investiert, sinkt die Notwendigkeit für europäische Finanzierungen; zurückgehende Mittel wären hierbei kein Indiz für nachlassendes Interesse. Zur umfassenden Beurteilung ist eine Beobachtung über einen längeren Zeitraum erforderlich, gleichzeitig sind weitere Quellen der öffentlichen Finanzierung zu berücksichtigen. Diesbezüglich erfasst der Indikator zwar die Ausgaben der EU, nicht jedoch die der einzelnen Mitgliedsländer. Die öffentliche Forschungsförderung in Deutschland (Bundesmittel) wird vom Indikator GT-05 dokumentiert. 
a) Tabelle 6: Förderung von EU-Projekten mit deutscher Beteiligung im Bereich der Gentherapie (nach Projekten)

\begin{tabular}{|l|l|c|c|}
\hline Projektname & $\begin{array}{l}\text { Laufzeit, nach aufsteigendem } \\
\text { Laufzeitbeginn }\end{array}$ & $\begin{array}{c}\text { Fördervolumen } \\
\text { gesamt in Mio. } \\
\text { Euro }\end{array}$ & $\begin{array}{c}\text { Durchschnittliches } \\
\text { Fördervolumen pro } \\
\text { Jahr in Mio. Euro }\end{array}$ \\
\hline
\end{tabular}

\section{EU-Forschungsrahmenprogramm}

\begin{tabular}{|l|l|c|c|}
\hline CONSERT & November 2004 - April 2009 & 11,6 & 2,6 \\
\hline GIANT & Januar 2005 - Juni 2010 & 9,7 & 1,8 \\
\hline RIGHT & Januar 2005 - Juni 2009 & 11,2 & 2,5 \\
\hline Improved precision & Januar 2005 - Juni 2008 & 3,5 & 1,0 \\
\hline Epi-Vector & Januar 2005 - Juni 2008 & 2,1 & 0,6 \\
\hline MOLEDA & Januar 2005 - Juni 2008 & 2,4 & 0,7 \\
\hline ANGIOSKIN & Mai 2005 - Oktober 2009 & 2,8 & 0,6 \\
\hline ATTACK & November 2005 - Oktober 2010 & 12 & 2,4 \\
\hline INTHER & November 2005 - Januar 2009 & 2,8 & 0,9 \\
\hline THERADPOX & Dezember 2005 - November 2008 & 2,4 & 0,8 \\
\hline THOVLEN & Januar 2006 - Juli 2009 & 2,5 & 0,7 \\
\hline CLINIGENE & April 2006 - Oktober 2011 & 12 & 2,1 \\
\hline Magselectofection & Mai 2006 - Dezember 2009 & 2,8 & 0,8 \\
\hline PoIExGene & Juni 2006 - November 2009 & 2,1 & 0,6 \\
\hline BACULOGENES & Januar 2007 - März 2010 & 2,5 & 0,8 \\
\hline ZNIP & Januar 2007 - Dezember 2009 & 2,3 & 0,8 \\
\hline 7. EU-Forschungsrahmenprogramm & & \\
\hline
\end{tabular}

\begin{tabular}{|l|l|c|c|}
\hline TARCC & Januar 2008 - Juni 2011 & 3 & 0,9 \\
\hline ANTICARB & März 2008 - August 2011 & 3 & 0,9 \\
\hline ADAMANT & April 2008 - März 2011 & 3 & 1,0 \\
\hline CRUMBS IN SIGHT & April 2008 - Mai 2012 & 3 & 0,7 \\
\hline EUCLYD & Mai 2008 - April 2011 & 3 & 1,0 \\
\hline NANOPHOTO & Juli 2008 - Dezember 2011 & 2,5 & 0,7 \\
\hline BRAINCAV & Oktober 2008 - März 2013 & 3 & 0,7 \\
\hline NEUGENE & Oktober 2008 - März 2012 & 3 & 0,9 \\
\hline PERSIST & Januar 2009 - Juni 2013 & 11,2 & 2,5 \\
\hline AIPGENE & Januar 2011 - Dezember 2013 & 3,3 & 1,1 \\
\hline TREATRUSH & Februar 2010 - Januar 2014 & 6 & 1,5 \\
\hline IDEA & März 2010 - Februar 2015 & 10,3 & 2,1 \\
\hline ACADEMIC GMP & September 2010 - Mai 2013 & 0,5 & 0,2 \\
\hline GENEGRAFT & März 2011 - Februar 2016 & 5 & 1,0 \\
\hline EXPLORE & Januar 2012 - Dezember 2016 & 2,5 & 0,5 \\
\hline TARGETAMD & November 2012 - Oktober 2016 & 6 & 1,5 \\
\hline PHENORAT & November 2012 - Oktober 2016 & 0,9 & 0,2 \\
\hline NET4CGD & Dezember 2012 - November 2016 & 6 & 1,5 \\
\hline EUROFANCOLEN & Januar 2013 - Dezember 2017 & 5,4 & 1,1 \\
\hline EVERREST & Januar 2013 - Dezember 2018 & 6 & 1,0 \\
\hline BIOSYNCEN & Februar 2013 - Januar 2018 & 1,7 & 0,3 \\
\hline SUPERIST & Mai 2013 - April 2016 & 6 & 2,0 \\
\hline
\end{tabular}

Jeweils aktualisierte Daten; Unterschiede zu früheren Veröffentlichungen möglich. Quelle: siehe Indikatorenblatt GT-06. 
b) Abbildung 9: Förderung von EU-Projekten mit deutscher Beteiligung im Bereich der Gentherapie (nach Laufzeit)

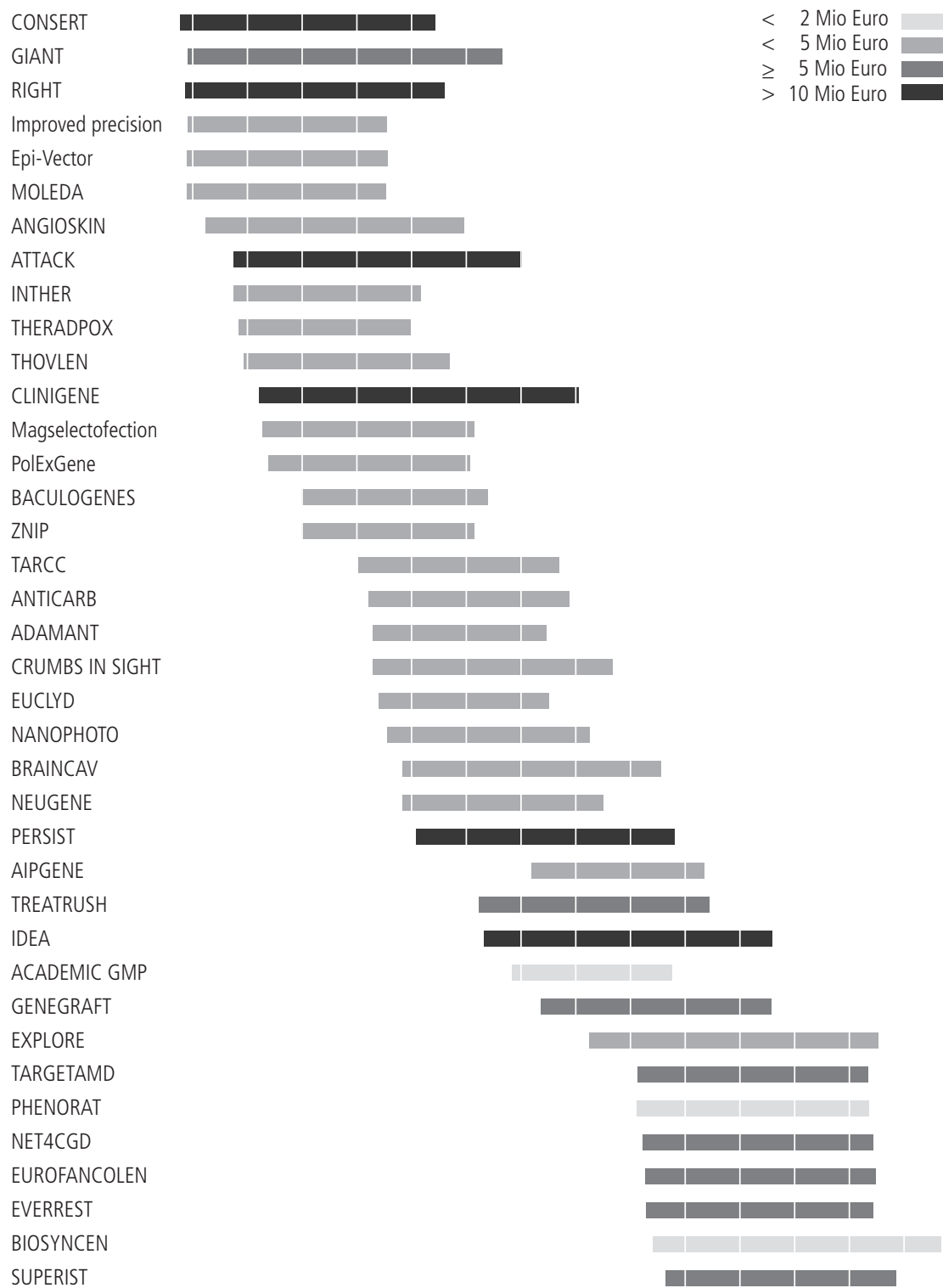

Okt. Okt. Okt. Okt. Sep. Sep. Sep. Sep. Sep. Sep. Sep. Sep. Sep. Sep. Sep.

$\begin{array}{lllllllllllllll}04 & 05 & 06 & 07 & 08 & 09 & 10 & 11 & 12 & 13 & 14 & 15 & 16 & 17 & 18\end{array}$

Jeweils aktualisierte Daten; Unterschiede zu früheres Jeröffentichungen mö̈glich Quelle: siehe Indikatorenblatt GT-06. 
c) Abbildung 10: Förderung von EU-Projekten mit deutscher Beteiligung im Bereich der Gentherapie (nach Jahren, in Mio. Euro)

25

20

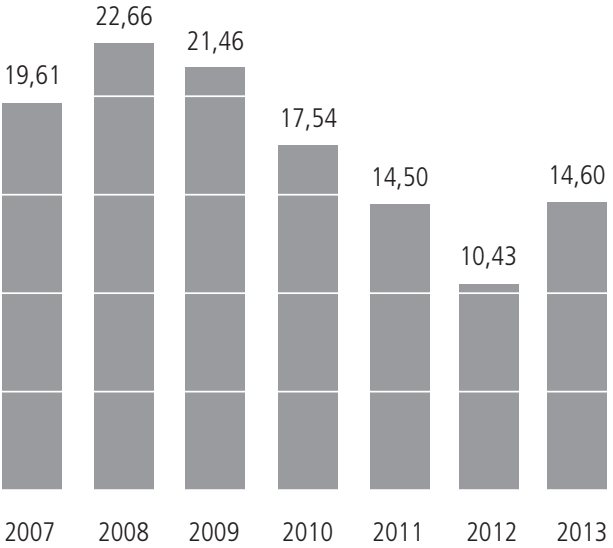

Jeweils aktualisierte Daten; Unterschiede zu früheren Veröffentlichungen möglich. Quelle: siehe Indikatorenblatt GT-06. 
Laufende Nr.: GT-07

Problemfeld: Forschungsstandort Deutschland + Transfer in Produkte + Realisierung wissenschaftlicher Zielsetzungen + Realisierung medizinischer Zielsetzungen

\title{
INDIKATOR: ANZAHL DER KLINISCHEN STUDIEN ZUR GENTHERAPIE
}

\section{DATENQUELLE:}

Wiley, Gene Therapy Clinical Trials Worldwide, Unter http://www.abedia.com/wiley/index.html

Zugriff: Juli 2013, Stand der Daten: Juli 2013.

\section{VERFÜGBARKEIT DER DATEN:}

\author{
öffentlich
}

\section{ABGRENZUNG DER BERECHNUNGSGRÖSSEN:}

Als Grundlage für die nachfolgend aufbereiteten Daten dienen die Zahlen der Wiley-Datenbank. In dieser Datenbank sind die weltweit genehmigten, laufenden und abgeschlossenen Gentransferstudien verzeichnet. Daraus ergibt sich eine fortlaufende Addierung der Daten; die rückläufigen Zahlen bei Belgien und Frankreich können demzufolge nur mit datenbankimmanenten Fehlzählungen begründet werden. Die Gesamtheit der jährlich zugrunde liegenden Studien (N) ist jeweils angegeben.

\section{GLIEDERUNG DER ABBILDUNG:}

a) Anzahl der weltweit durchgeführten Gentherapiestudien; seit 2001, dem Beginn des Gentechnologieberichtes;

b) Kontinentale Verteilung von klinischen Gentransferstudien;

c) Verteilung klinischer Studien in Europa;

d) Verteilung von Gentransferstudien nach Phasen

\section{BERECHNUNGSHÄUFIGKEIT:}

Die Daten werden in der Regel halbjährlich bei gleichbleibender Logik aktualisiert; für den Gentechnologiebericht werden seit Juli 2007 Daten regelmäßig recherchiert und archiviert.

\section{AUSSAGEFÄHIGKEIT:}

Der Indikator gibt Auskunft darüber, in welchem Maße auf nationaler und internationaler Ebene der wissenschaftlichtechnische Fortschritt auf dem Gebiet der Gentherapie im Allgemeinen zu einer Durchführung von klinischen Studien im Speziellen geführt hat und welchen Reifegrad mögliche medizinische Anwendungen gegenwärtig besitzen. 
a) Abbildung 11: Anzahl der weltweit durchgeführten Gentherapiestudien (absolut)

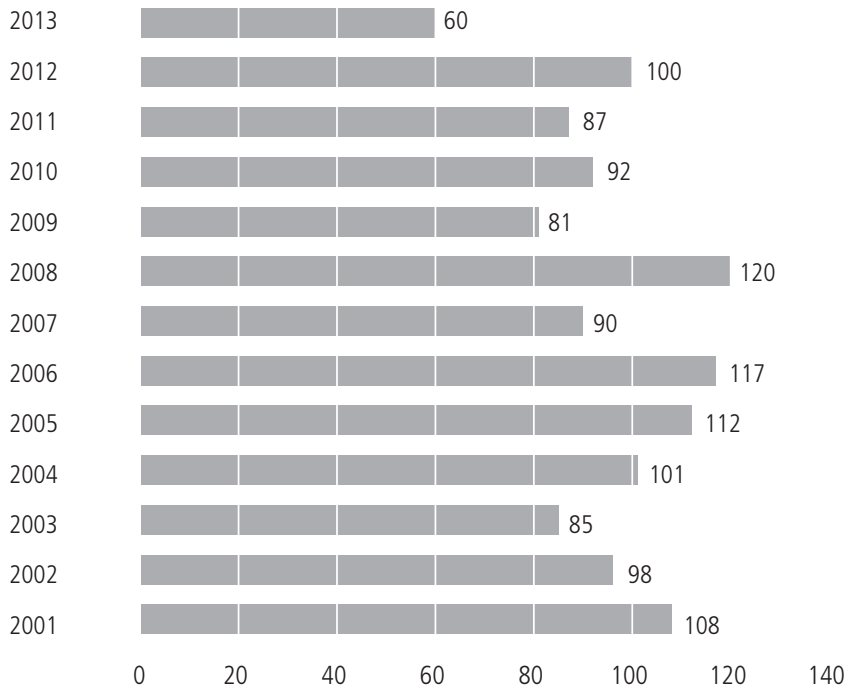

Quelle: siehe Indikatorenblatt GT-07.

b) Abbildung 12: Kontinentale Verteilung von klinischen Gentransferstudien (in Prozent)

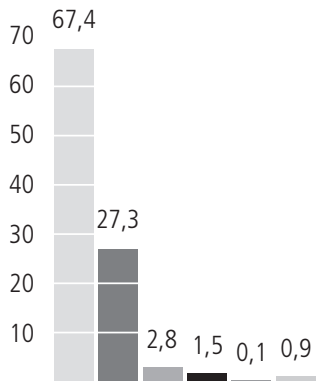

Juli $2007 \quad N=1309$

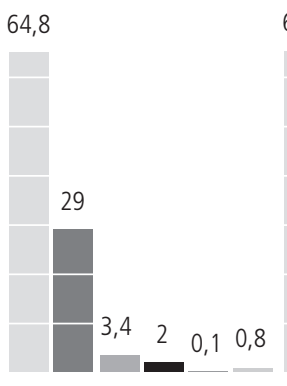

März 2009 N=1537
65,2

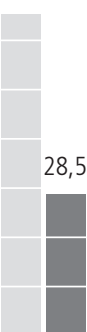

$\begin{array}{llll}3,7 & 1,8 & 0,1 & 0,8\end{array}$

Juni $2011 \mathrm{~N}=1714$
63,9

25,9

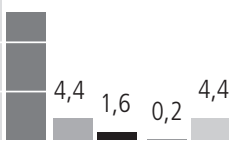

Juli 2013 N=1970

Amerika Europa

Quelle: siehe Indikatorenblatt GT-07. 
c) Tabelle 7: Verteilung klinischer Studien in Europa (absolut)

\begin{tabular}{|l|c|c|c|c|c|c|c|}
\hline & Jul 07 & Mrz 08 & Mrz 09 & Jun 10 & Jun 11 & Jun 12 & Jul 13 \\
\cline { 2 - 8 } & $\mathrm{N}=1309$ & $\mathrm{~N}=1347$ & $\mathrm{~N}=1537$ & $\mathrm{~N}=1644$ & $\mathrm{~N}=1714$ & $\mathrm{~N}=1843$ & $\mathrm{~N}=1970$ \\
\hline UK & 150 & 150 & 184 & 193 & 197 & 203 & 204 \\
\hline Deutschland & 74 & 74 & 76 & 79 & 79 & 81 & 82 \\
\hline Schweiz & 42 & 42 & 46 & 46 & 50 & 50 & 50 \\
\hline Frankreich & 20 & 20 & 41 & 41 & 45 & 53 & 48 \\
\hline Belgien & 19 & 19 & 23 & 24 & 25 & 27 & 22 \\
\hline Niederlande & k.A. & 16 & 24 & 26 & 27 & 31 & 33 \\
\hline Finnland & 3 & 3 & 4 & 4 & 5 & 6 & 6 \\
\hline Österreich & 2 & 2 & 2 & 2 & 2 & 2 & 2 \\
\hline Dänemark & 2 & 2 & 2 & 2 & 2 & 2 & 2 \\
\hline Tschechien & 1 & 1 & 1 & 1 & 1 & 1 & 1 \\
\hline
\end{tabular}

Quelle: siehe Indikatorenblatt GT-07.

d) Abbildung 13: Verteilung von Gentransferstudien nach Phasen (international, in Prozent)

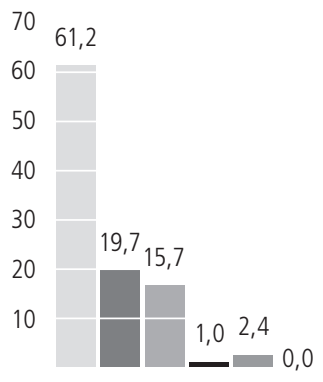

Juli $2007 \mathrm{~N}=1309$
60,9

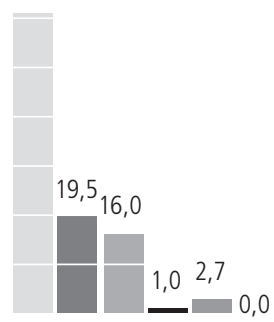

März 2008 N=1347
60,4

60,5

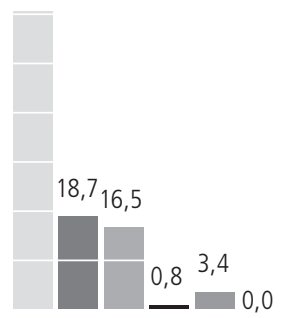

März 2009 N=1537
$18,716,2$

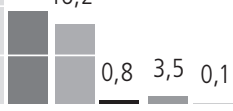

Juni $2010 \quad N=1644$

Phase I

Phase I/II

Phase II

Phase II/III

Phase III

Phase IV 


\section{Fortsetzung Abbildung 13}

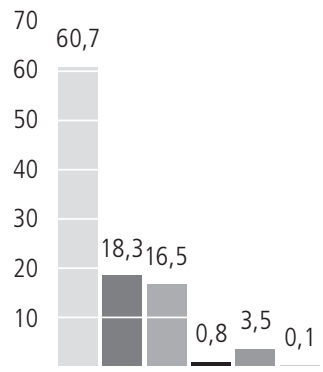

Juni $2011 \mathrm{~N}=1714$
59,6

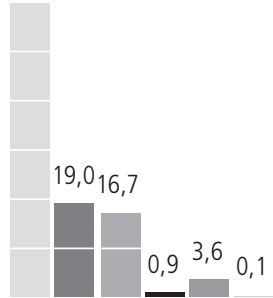

Juni $2012 N=1843$
59,4

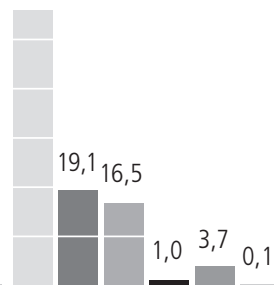

Juli $2013 N=1970$

Phase I

Phase I/II

Phase II

Phase III

Phase IV 
Laufende Nr.: GT-08

Problemfeld: Forschungsstandort Deutschland + Realisierung medizinischer Zielsetzungen

\section{INDIKATOR: VERTEILUNG DER INDIKATIONEN BEI KLINISCHEN STUDIEN ZUR GENTHERAPIE}

\section{DATENQUELLE:}

Wiley, Gene Therapy Clinical Trials Worldwide. Unter:

http://www.abedia.com/wiley/indications.php

Zugriff: Juli 2013, Stand der Daten: Juli 2013.

VERFÜGBARKEIT DER DATEN:

öffentlich

\section{ABGRENZUNG DER BERECHNUNGSGRÖSSEN:}

Als Grundlage für die nachfolgend aufbereiteten Daten dienen die Zahlen der Wiley-Datenbank. In dieser Datenbank sind die weltweit genehmigten, laufenden und abgeschlossenen Gentransferstudien verzeichnet. Die Gesamtheit der jährlich zugrunde liegenden Studien (N) ist jeweils angegeben. Die Kategorien "Gene marking" und "Healthy volunteers" werden nicht mit in die Zählung aufgenommen; aufgrund dessen ergibt sich eine niedrigere Summe als $100 \%$ pro Jahr.

\section{GLIEDERUNG DER DARSTELLUNG:}

siehe Abbildung, zweijährlich

\section{BERECHNUNGSHÄUFIGKEIT:}

Die Daten werden in der Regel halbjährlich bei gleichbleibender Logik aktualisiert; für den Gentechnologiebericht werden seit Juli 2007 Daten regelmäßig recherchiert und archiviert. Aus Gründen der Darstellbarkeit werden hier nur die Jahre 2007, 2009, 2011 und 2013 veröffentlicht; weitere Daten können bei den Autoren angefragt werden; auf ältere Publikationen wird verwiesen (zuletzt Domasch/Osterheider 2011, S. 285f.)

Abbildung 14: Indikationen für gentherapeutische Studien (international, in Prozent)

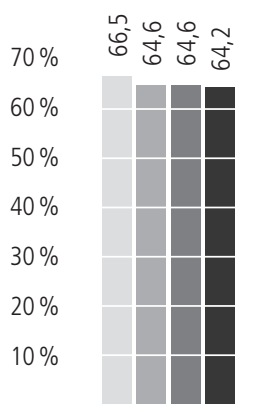

Krebserkrankungen

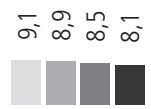

Herz-KreislaufErkrankungen

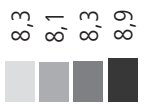

monogene Erbkrankheiten
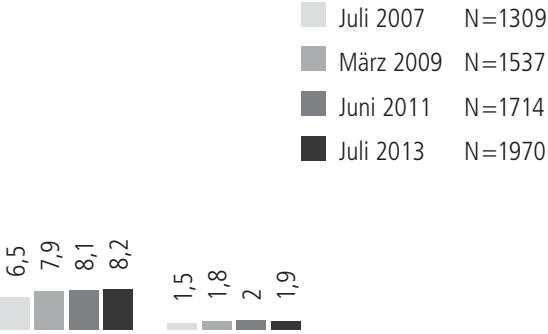

$\stackrel{\infty}{\longleftarrow} \stackrel{\infty}{-} \stackrel{\varrho}{-}$

Infektionskrankheiten neurologische Krankheiten

* Entzündliche Erkrankungen werden erst sejt duni 2011 gefühit. Quelle: siehe indikatorenblatt GT-08. 


\section{AUSSAGEFÄHIGKEIT:}

Der Indikator gibt einen Überblick über die Indikationen, die im Rahmen von Gentransferstudien mithilfe von gentherapeutischen Maßnahmen erforscht werden. Die Verteilung der Indikationen lässt bis zu einem gewissen Grad zum einen Rückschlüsse auf die gesamtgesellschaftliche Relevanz und zum anderen auf die Attraktivität im Bereich der Forschung und Entwicklung vonseiten der Industrie zu. In Anbetracht der zum Teil bestehenden Risiken und der Komplexität der Methoden spielen auch andere Faktoren eine Rolle. So lässt sich die Anwendung eines potenziell riskanten gentherapeutischen Verfahrens vor dem Hintergrund lebensbedrohlicher Krankheiten eher rechtfertigen, als im Kontext beherrschbarer Krankheiten.

\section{Fortsetzung Abbildung 14}

$70 \%$

$60 \%$

$50 \%$

$40 \%$

$30 \%$

$20 \%$
$10 \% \quad$ gே Е

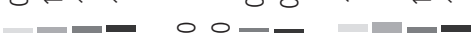
Augen- entzündliche Andere krankheiten Erkrankungen*


Laufende Nr.: GT-09

Problemfeld: Forschungsstandort Deutschland + Realisierung wissenschaftlicher Zielsetzungen

\section{INDIKATOR: GENUTZTE VEKTOREN IN KLINISCHEN STUDIEN ZUR GENTHERAPIE}

\section{DATENQUELLE:}

Wiley, Gene Therapy Clinical Trials Worldwide. Unter:

http://www.abedia.com/wiley/vectors.php

Zugriff: Juli 2013, Stand: Juli 2013.

VERFÜGBARKEIT DER DATEN:

öffentlich

\section{ABGRENZUNG DER BERECHNUNGSGRÖSSEN:}

Als Grundlage für die nachfolgend aufbereiteten Daten dienen die Zahlen der Wiley-Datenbank. In dieser Datenbank sind die weltweit genehmigten, laufenden und abgeschlossenen Gentransferstudien verzeichnet. Die Gesamtheit der jährlich zugrunde liegenden Studien (N) ist jeweils angegeben.

\section{GLIEDERUNG DER DARSTELLUNG:}

siehe Abbildung, zweijährlich

\section{BERECHNUNGSHÄUFIGKEIT:}

Die Daten werden in der Regel halbjährlich bei gleichbleibender Logik aktualisiert; für den Gentechnologiebericht werden seit Juli 2007 Daten regelmäßig recherchiert und archiviert. Aus Gründen der Darstellbarkeit werden hier nur die Jahre 2007, 2009, 2011 und 2013 veröffentlicht; weitere Daten können bei den Autoren angefragt werden; auf ältere Publikationen wird verwiesen (zuletzt Domasch/Osterheider 2011, S. 287ff.)

\section{AUSSAGEFÄHIGKEIT:}

Der Indikator gibt einen Überblick über die genutzten Vektoren in Gentransferstudien auf internationaler Ebene. Vektoren gelten als Schlüsselelement der Gentherapie. Der Schwerpunkt liegt derzeit auf dem Einsatz von verschiedenen viralen Vektoren. Aufgrund des hohen Risikos insertionsbedingter schwerwiegender Nebenwirkungen von herkömmlichen retroviralen Vektoren werden nach Möglichkeit vermehrt andere virale Alternativen entwickelt beziehungsweise nicht-virale Transfermethoden eingesetzt.

Abbildung 15: Genutzte Vektoren in klinischen Studien zur Gentherapie (international, in Prozent)

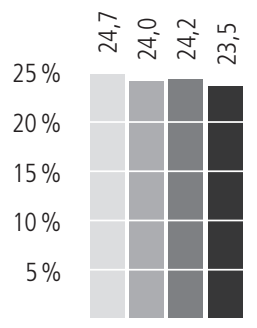

Adenoviren

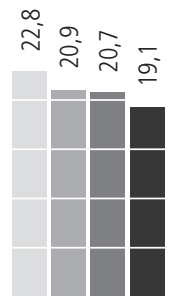

Retroviren

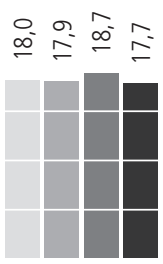

nackte DNA

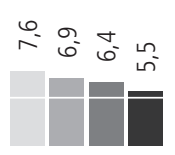

Lipofektion

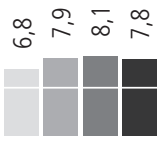

Vaccinia Viren

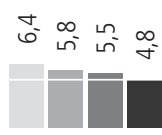

Poxviren

* Lentiviren werden seit Juni 2010 in der Wiley-Datenbank gelistet und dementsprechend ab hier aufgenommen;

** RNA-Transfer wurde als Kategorie nur bis einschließlich März 2.009 gelistet. Quelle: siehe Indikatorenblatt GT-09. 
Fortsetzung Abbildung 15

Juni $2007 \quad N=1309$

März 2009 N = 1537

Juni $2011 \quad N=1714$

$25 \%$

- Juli $2013 \quad N=1970$

$20 \%$

$15 \%$

$10 \%$

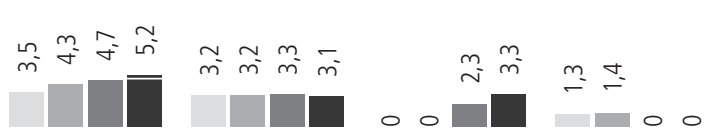

Adeno-assoziierte Herpes Simplex

Lentiviren*

RNA-Transfer ** Viren

Viren

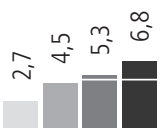

Andere $\stackrel{\sim}{m} \approx \sim \sim$

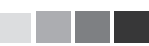

Unbekannt 
Laufende Nr:: GT-10

Problemfeld: Forschungsstandort Deutschland + Transfer in Produkte

\section{INDIKATOR: ANZAHL DER ANTRÄGE AUF KLINISCHE PRÜFUNGEN IM BEREICH DER GENTHERAPIE IN DEUTSCHLAND}

\section{DATENQUELLE:}

Paul-Ehrlich-Institut (PEI). Unter:

http://www.pei.de/DE/infos/pu/genehmigung-klinische-pruefung/bearbeitungsstatistik-antraege/archiv/ archiv-statistik-node.html

Zugriff: Juli 2013, Stand der Daten: Dezember 2012.

\section{VERFÜGBARKEIT DER DATEN:}

öffentlich

\section{ABGRENZUNG DER BERECHNUNGSGRÖSSEN:}

Der Indikator bildet die aktuelle Antragslage des Paul-Ehrlich-Instituts (PEI) zu klinischen Prüfungen für die Produktgruppe „Gentransfer-Arzneimittel/GVO” ab. Erfasst werden „alle Anträge auf klinische Prüfungen, die seit August 2004 am PEl eingegangen sind. Dabei kann es sich sowohl um monozentrische (für Deutschland) und/oder multizentrische Studien (mit deutscher Beteiligung) handeln; eine diesbezügliche Differenzierung bzw. Aufschlüsselung der Daten ist auf den Seiten des PEl nicht ersichtlich.

\section{GLIEDERUNG DER DARSTELLUNG:}

siehe Abbildung

\section{BERECHNUNGSHÄUFIGKEIT:}

jährlich

\section{AUSSAGEFÄHIGKEIT:}

Der Indikator gibt Auskunft darüber, in welchem Maße der wissenschaftlich-technische Fortschritt auf dem Gebiet der Gentherapie im Allgemeinen zu einer Durchführung von klinischen Studien im Speziellen geführt hat und welchen Reifegrad mögliche medizinische Anwendungen gegenwärtig besitzen. Im Besonderen gibt der Indikator einen Hinweis darauf, in welchem Maße Gentransferarzneimittel in Deutschland vor der Zulassung stehen.

Tabelle 8: Anträge auf klinische Prüfungen auf dem Gebiet der Gentransferarzneimittel in Deutschland (nach Phasen)

\begin{tabular}{|l|c|c|c|c|c|c|c|c|c|}
\hline & 2005 & 2006 & 2007 & 2008 & 2009 & 2010 & 2011 & 2012 & Gesamt \\
\hline Phase I & 1 & 5 & 3 & 1 & 1 & 1 & 4 & 4 & 20 \\
\hline Phase II & 3 & 1 & 2 & 4 & 1 & 2 & 2 & 2 & 17 \\
\hline Phase III & 2 & 1 & 3 & 1 & 1 & 1 & 3 & 0 & 12 \\
\hline Phase IV & 0 & 0 & 0 & 0 & 0 & 0 & 0 & 0 & 0 \\
\hline Gesamt & 6 & 7 & 8 & 6 & 3 & 4 & 9 & 6 & 49 \\
\hline
\end{tabular}

Jeweils aktualisierte Daten; Unterschiede zu früheren Veröffentlichungen möglich.

Quelle: siehe Indikatorenblatt GT-10. 
Laufende Nr:: GT-11

Problemfeld: Forschungsstandort Deutschland + Transfer in Produkte

\section{INDIKATOR: ANZAHL DER PATENTANMELDUNGEN IM BEREICH GENTHERAPIE IN DEUTSCHLAND}

\section{DATENQUELLE:}

Datenbank des Deutschen Patent- und Markenamtes. Unter:

http://depatisnet.dpma.de/

Zugriff: August 2013, Stand der Daten: August 2013.

\section{VERFÜGBARKEIT DER DATEN:}

öffentlich

\section{ABGRENZUNG DER BERECHNUNGSGRÖSSEN:}

Die Daten stammen aus einer Datenbank-Recherche beim Deutschen Patentamt; sie wurden über eine Expertensuche mit folgenden Suchalgorithmen erhoben ( $\mathrm{AY}=$ Anmeldejahr; $\mathrm{TI}=$ Titel; $\mathrm{PA}=\mathrm{DE}$ (Anmelder mit Länderkürzel DE); jeweils für die Jahre 2001 bis 2013):

$\mathrm{AY}=2001 \mathrm{UND} \mathrm{TI}=$ gentherap? UND PA $=\mathrm{DE}$

$A Y=2001$ UND TI $=$ "gene therap?" UND PA $=$ DE

$A Y=2001$ UND TI $=$ vektor? UND PA $=$ DE

$\mathrm{AY}=2001 \mathrm{UND} \mathrm{TI}=$ vector? UND PA $=\mathrm{DE}$

Ein offensichtlicher Nachteil der Titel-Stichwortsuche v.a. zu „Vektoren“ ist, dass auch vermeintlich fachfremde Patente angezeigt werden; diese werden als Datenbank-immanent eingestuft und systematisch mitgezählt!

\section{GLIEDERUNG DER DARSTELLUNG:}

siehe Abbildung; beginnend mit 2001, dem Beginn des Gentechnologieberichtes

\section{BERECHNUNGSHÄUFIGKEIT:}

jährlich

\section{AUSSAGEFÄHIGKEIT:}

Die Anzahl der Patente kann sowohl als Gradmesser für die wissenschaftliche Aktivität sowie als Frühindikator für die wirtschaftliche Etablierung der Entwicklungen im Bereich der Gentherapie dienen. Der Indikator liefert jedoch keine Informationen über die reale wissenschaftliche oder wirtschaftliche Bedeutung eines Patentes oder den Grad seiner Anwendung. Ferner ist davon auszugehen, dass nicht ausschließlich Patente in Deutschland, sondern auch beim Europäischen Patentamt angemeldet werden; generelle Entwicklungstrends sind indes vergleichbar.

Allgemein erlaubt ein Patent seinem Inhaber die ausschließliche kommerzielle Nutzung der Erfindung für einen bestimmten Zeitraum. Dies bedeutet, dass Wettbewerber vor Ablauf des Patenschutzes keinen kommerziellen Gebrauch von der Erfindung machen dürfen, es sei denn, der Patentinhaber erlaubt dies durch die Vergabe von Lizenzen. Nur Erfindungen, die neu sind, die eine Lösung für ein technisches Problem darstellen, auf einer erfinderischen Tätigkeit beruhen und die gewerblich angewendet werden können, sind patentfähig. Entdeckungen dagegen können nicht patentiert werden.

Spätestens 18 Monate nach Patentanmeldung müssen Einzelheiten der Erfindung veröffentlicht werden. Auf diese Weise wird sichergestellt, dass wissenschaftliche und technologische Kenntnisse der Öffentlichkeit zugänglich gemacht werden und der verfügbare Wissensstand erhöht wird. Darüber hinaus wird durch diese Vorgehen ein freier und offener Austausch von Information gefördert.

Patente und Lizenzen schaffen Anreize für Forschungen und Investitionen. Durch die Möglichkeit der alleinigen Vermarktung der Innovation für einen festen Zeitraum, wächst die Bereitschaft der Unternehmen, höhere finanzielle Risiken für langwierige Forschungs- und Entwicklungsarbeit einzugehen. 
Abbildung 16: Patentanmeldungen zur Gentherapie beim Deutschen Patentamt (nach Titel-Stichworten und Anmeldejahr)

2013

\begin{tabular}{c|c}
2012 & 3 \\
2011 & 3 \\
2010 & 1 \\
2009 & 13
\end{tabular}

2008

2007

2006

2005

2004

2003

2002

2001
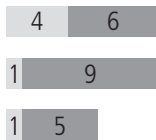
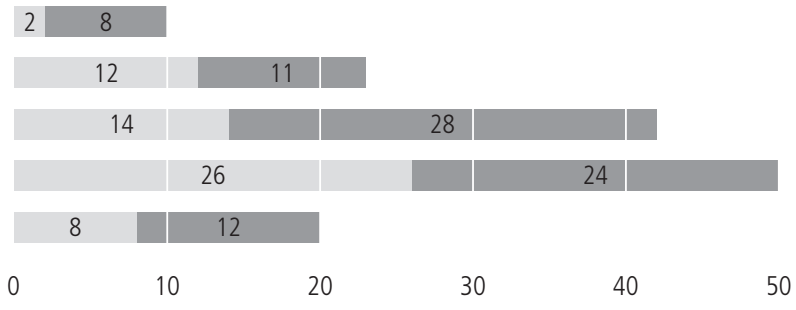

$2013 \quad 2$

vektor *

20123

27

vector *

2011

2010

2009

2008

2007

2006

2005

2004

2003

2002

2001

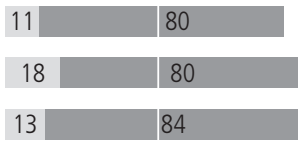

$15 \quad 70$
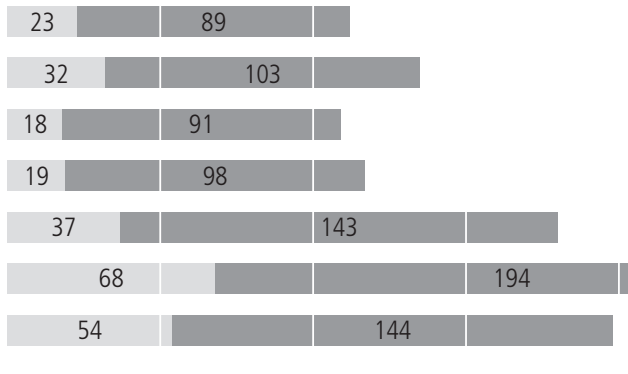

0

50

100

150

200

250

Doppelzählungen Datenbank-immanent möglich (sowohl dt./engl. als auch der Stichworte) Quelle: siehe Indikatorenblatt GT-11. 
Laufende Nr:: GT-12

Problemfeld: Forschungsstandort Deutschland + Transfer in Produkte

\section{INDIKATOR: ANZAHL DER AUF DEM GEBIET DER GENTHERAPIE ARBEITENDEN FIRMEN IN DEUTSCHLAND}

\section{DATENQUELLE:}

Erhebungen im Auftrag des Bundesministeriums für Bildung und Forschung (BMBF),

Informationsplattform Biotechnologie.de, Datenbank unter:

http://www.biotechnologie.de/BIO/Navigation/DE/Datenbank/biotechnologie-db.html?

Biotechnologie-Firmenumfrage 2007 bis 2013, jeweils für die Stichtage 31.12. des Vorjahres.

zuletzt Zugriff: August 2013, Stand der Daten: Dezember 2012.

\section{VERFÜGBARKEIT DER DATEN:}

öffentlich, Präzisierung via biotechnologie.de

\section{ABGRENZUNG DER BERECHNUNGSGRÖSSEN:}

Die Daten wurden nach den Leitlinien der Organisation für wirtschaftliche Zusammenarbeit und Entwicklung (OECD) erhoben. Berücksichtigt werden Firmen, die nach der OECD-Definiton im Bereich der "DNA- und/der RNA-Vektoren" (Gentherapie, Virale Vektoren, früher „Subzelluläre Organismen“) sind und deren Tätigkeitsbereich Gesundheit/Medizin (d. h. Entwicklung von Therapeutika und/oder Diagnostika für den human-medizinischen Bereich, Drug Delivery, Gewebe-Ersatz) und nichtspezifische Anwendungen (d. h. auf biotechnologischen Prinzipien basierende Geräte und Reagenzien für die Forschung sowie Dienstleistungen in diesem Bereich) ist. Des Weiteren sind nur dedizierte Biotechnologieunternehmen aufgeführt, das heißt, Firmen deren Unternehmensziel wesentlich oder ausschließlich in der Biotechnologie liegt. Zu ergänzen ist, dass Produktion und Forschung im Bereich der Gentherapie zumeist lediglich nur kleine Tätigkeitsbereiche umfasst beziehungsweise als eine ferne Option eingestuft wird.

Die Zahlen dokumentieren den Stand des 1. Januar des genannten Jahres und verweisen auf das jeweilige Vorjahr (siehe Datenquelle); um einheitliche Veröffentlichungslogiken zu bisherigen Publikationen zu gewährleisten, wird die bisher genutzte Jahreszählung beibehalten.

\section{GLIEDERUNG DER DARSTELLUNG:}

a) Anwendungsbereiche (Medizin/nichtspezifisch) und Sektor (Forschung/Produkte)

b) nach Mitarbeiterzahlen

\section{BERECHNUNGSHÄUFIGKEIT:}

jährlich

\section{AUSSAGEFÄHIGKEIT:}

Der Indikator erlaubt Rückschlüsse darauf, in welchem Maße die wissenschaftlich-technische Entwicklung auf dem Gebiet der Gentherapie sich in Aktivitäten im Bereich der Wirtschaft umgesetzt hat. Allerdings ist die bloße Zahl der Firmen nicht direkt mit wirtschaftlicher Aktivität gleichzusetzen; hierfür wären konkrete Umsatzzahlen der Firmen erforderlich.

Zu berücksichtigen ist ferner, dass aufgrund einer steigenden Firmenzahl nicht automatisch auf Produkte geschlossen werden kann, die für jedermann zugänglich sind und eine breite medizinische Anwendung finden. Im frühen Stadium einer technischen Innovation fließen die meisten Produkte selbst wieder in die weitere Forschung und Entwicklung ein. 
a) Abbildung 17: Auf dem Gebiet der Gentherapie arbeitende Firmen (Produkte \& Forschung)

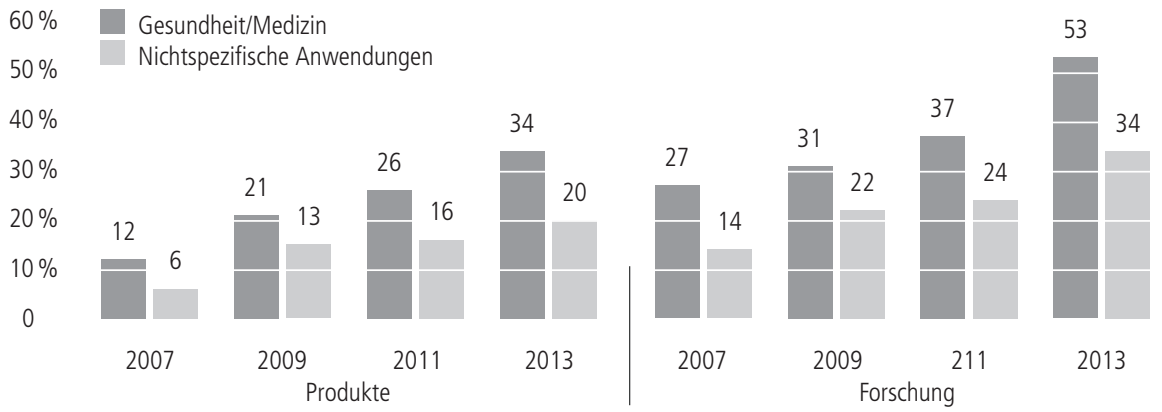

Doppelzählungen der Firmen, die sowohl in den Bereichen Forschung als auch Produkte tätig sind; Quelle: siehe Indikatorenblatt GT-12. 
b) Abbildung 18: Auf dem Gebiet der Gentherapie arbeitende Firmen (nach Anzahl der Mitarbeitenden)

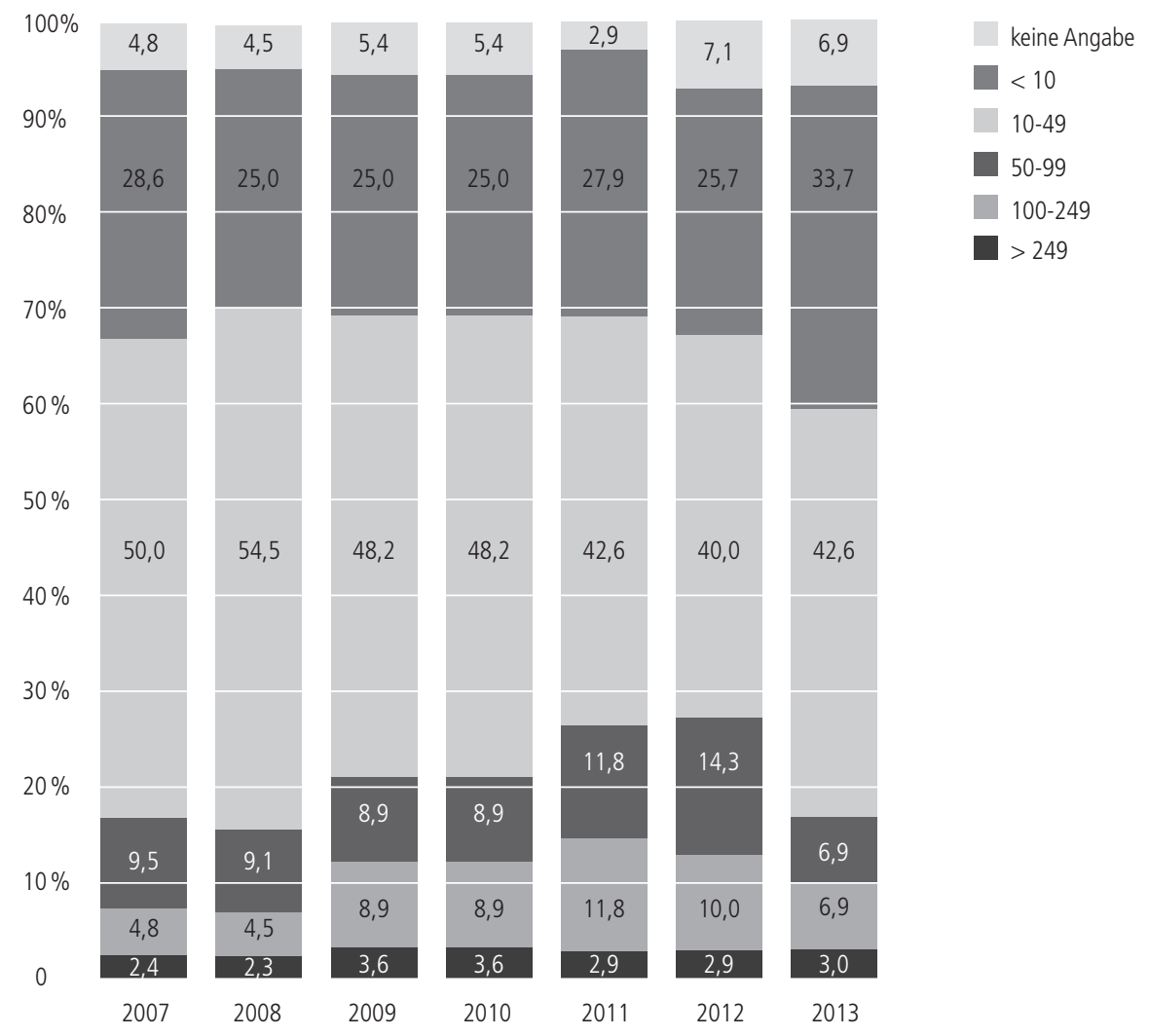

Quelle: siehe Indikatorenblatt GT-12. 
Laufende Nr:: GT-13

Problemfeld: Forschungsstandort Deutschland

\section{INDIKATOR: ANZAHL DER KOMMERZIELL BESCHÄFTIGTEN IM BEREICH GENTHERAPIE IN DEUTSCHLAND}

\section{DATENQUELLE:}

Erhebungen im Auftrag des Bundesministeriums für Bildung und Forschung (BMBF),

Informationsplattform Biotechnologie.de, Datenbank unter:

http://www.biotechnologie.de/BIO/Navigation/DE/Datenbank/biotechnologie-db.html?

Biotechnologie-Firmenumfrage 2007 bis 2013, jeweils für die Stichtage 31.12. des Vorjahres.

zuletzt Zugriff: August 2013, Stand der Daten: Dezember 2012.

\section{VERFÜGBARKEIT DER DATEN:}

öffentlich

\section{ABGRENZUNG DER BERECHNUNGSGRÖSSEN:}

Die Daten wurden nach den Leitlinien der Organisation für wirtschaftliche Zusammenarbeit und Entwicklung (OECD) erhoben. Berücksichtigt werden Institutionen, die nach der OECD-Definiton im Bereich der „DNA- und/der RNA-Vektoren" (Gentherapie, Virale Vektoren, früher "Subzelluläre Organismen") tätig sind und deren Tätigkeitsbereich Gesundheit/Medizin (d. h. Entwicklung von Therapeutika und/oder Diagnostika für den human-medizinischen Bereich, Drug Delivery, Gewebe-Ersatz) und nichtspezifische Anwendungen (d. h. auf biotechnologischen Prinzipien basierende Geräte und Reagenzien für die Forschung sowie Dienstleistungen in diesem Bereich („Zulieferindustrie“)) umfassen. Des Weiteren sind nur Mitarbeiterinnen und Mitarbeiter dezidierter Biotechnologieunternehmen aufgeführt, das heißt, Firmen deren Unternehmensziel wesentlich oder ausschließlich in der Biotechnologie liegt.

Die Zahlen dokumentieren den Stand des 1. Januar des genannten Jahres und verweisen auf das jeweilige Vorjahr (siehe Datenquelle); um einheitliche Veröffentlichungslogiken zu bisherigen Publikationen zu gewährleisten, wird die bisher genutzte Jahreszählung beibehalten.

\section{GLIEDERUNG DER DARSTELLUNG:}

siehe Abbildung

\section{BERECHNUNGSHÄUFIGKEIT:}

prinzipiell jährlich

\section{AUSSAGEFÄHIGKEIT:}

Der Indikator erlaubt Rückschlüsse darauf, in welchem Maße die wissenschaftlich-technische Entwicklung auf dem Gebiet der Gentherapie sich in Aktivitäten im Bereich der Wirtschaft umgesetzt hat. Durch eine Kommerzialisierung der Forschungsergebnisse können ökonomische Gewinne erzielt und Arbeitsplätze gesichert beziehungsweise geschaffen werden. Die Zahl der Arbeitsplätze gilt als ein Schlüsselindikator für die Bewertung einer technischen Innovation als Plattform- beziehungsweise Basistechnologie, wobei diese Aussage erst im Vergleich mit anderen medizinisch-technischen Entwicklungen beurteilt werden kann. 
Abbildung 19: Kommerziell Beschäftigte im Bereich der Gentherapie in Deutschland

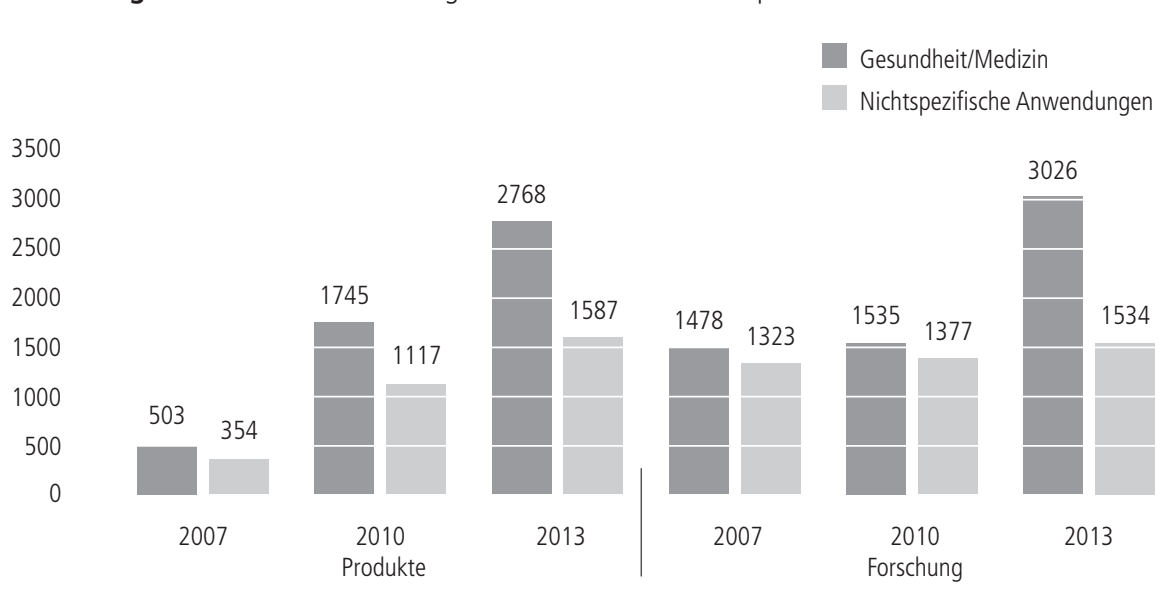

Anzahl der Firmen: N = 42 für 2007 (ein Unternehmen machte keine Angaben zur Mitarbeiterzahl); N = 56 für 2010 (drei Unternehmen machten keine Angaben zur Mitarbeiterzahl); N = 124 für 2013 (19 Unternehmen machten keine Angaben zur Mitarbeiterzahl). Jeweils aktualiserte Daten; Unterschiede zu früheren Veröffentlichungen möglich. Mehrfachzählungen aufgrund der Kreuzabfrage möglich.

Quelle: siehe Indikatorenblatt GT-13. 
Laufende Nr:: GT-14

Problemfeld: Transfer in Produkte

\section{INDIKATOR: ANZAHL DER KOMMERZIELLEN UND NICHT-KOMMERZIELLEN ANBIETER VON VEKTOREN}

\section{ANMERKUNG:}

Ein Schlüsselelement der Gentherapie sind Vektoren, insbesondere deren massenhafte, sichere, effiziente und leichte Produktion. Die Anzahl der kommerziellen und nicht-kommerziellen Anbieter auf dem Gebiet der Vektorproduktion lässt Rückschlüsse auf das wirtschaftliche und wissenschaftliche Potenzial der Vektortechnologie und damit der Gentherapie zu.

Diese Daten wurden nur einmalig erhoben und zuletzt in Domasch/Osterheider, 2011:298 veröffentlicht. Eine Fortschreibung der Daten ist aufgrund dessen (derzeit) nicht möglich; entsprechende Recherchen auch bei anderen Quellen werden permanent weitergeführt. 
Laufende Nr:: GT-15

Problemfeld: Öffentliche Wahrnehmung

\section{INDIKATOR: ANZAHL DER VERFÜGBAREN BÜCHER ZUM THEMA}

\section{DATENQUELLE:}

amazon - Onlinebuchhandel. Unter:

www.amazon.de

Zugriff: zuletzt Juli 2013, Stand: Juli 2013.

\section{VERFÜGBARKEIT DER DATEN:}

öffentlich

\section{ABGRENZUNG DER BERECHNUNGSGRÖSSEN:}

Für die Recherche wurde der marktführende Online-Buchhandel amazon.de genutzt; es wurde nach dem Titel "Gentherapie" unter "Bücher" und „Erweiterte Suche" gesucht; alle anderen Felder blieben leer; außerdem „alle Kategorien”, „alle Formate", Erscheinungsdatum = beliebig, „alle Anbieter". Die Datenerhebung erfolgt seit August 2011 und kann nicht rückwirkend erweitert werden.

Bei den Zahlen handelt es sich um sämtliche Treffer in der Datenbank; d.h. es werden alle Publikationen unabhängig ihres Erscheinungsjahres gelistet.

\section{GLIEDERUNG DER DARSTELLUNG:}

jährliches Mittel

\section{BERECHNUNGSHÄUFIGKEIT:}

monatlich

\section{AUSSAGEFÄHIGKEIT:}

Geht man davon aus, dass sich der interessierte Laie über das Thema "Gentherapie" via Lektüre nähern möchte, sind Online-Buchläden bzw. deren Internetpräsenz und entsprechende Suchoptionen unmittelbar von Interesse. Denn so bietet sich ein Überblick an Publikationen unterschiedlicher Akteure bzw. Akteursgruppen sowie verschiedener Stile; es wird eine Bandbreite an Möglickeiten vorgeschlagen, aus denen der interessierte Laie wählen kann. Insofern besteht ein Dialogangebot vonseiten des Buchhandels, resp. der Autorinnen und Autoren.

Abbildung 20: Anzahl verfügbarer Bücher zum Thema

50

40

30

20

10

0
48

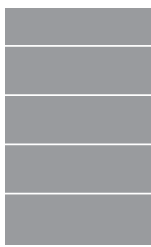

2011
50

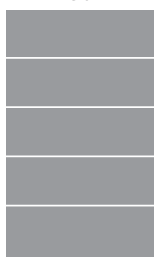

2012
48

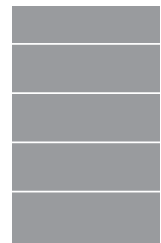

2013* 
Laufende Nr:: GT-16

Problemfeld: Öffentliche Wahrnehmung

\section{INDIKATOR: NEUERSCHEINUNGEN ZUM THEMA GENTHERAPIE}

\section{DATENQUELLE:}

Online-Katalog der Deutschen Nationalbibliothek. Unter:

https://portal.dnb.de

Zugriff: zuletzt Juni 2013, Stand: k. A.

VERFÜGBARKEIT DER DATEN:

öffentlich

\section{ABGRENZUNG DER BERECHNUNGSGRÖSSEN:}

Die Nationalbibliothek (DNB) ist bundesunmittelbare Anstalt des öffentlichen Rechts; ihre Aufgabe ist die systematische Archivierung und bibliografische Erfassung in Deutschland veröffentlichter Medienwerke. Der Katalog der Deutschen Nationalbibliothek erlaubt eine kostenlose Recherche innerhalb der umfassenden Bibliotheksbestände seit 1913. Er wird nach Anbieterangaben beständig weiter entwickelt.

Durchgeführt wurde eine erweiterte Suche nach "Titel" = Gentherapie (nach Jahren); gesucht wurde im "Gesamten Bestand" nach den "Materialarten" = Blindendrucke, Bücher, Online-Ressourcen, Elektronische Datenträger sowie Medienkombinationen.

Die Erhebung ist Stand Juni 2013 und dokumentiert aufgrund der zeitlich verzögerten Meldungen bzw. Listungen bei der DNB nicht den abschließenden Stand für das Jahr 2012*; aufgrund dessen ist auch das Jahr 2013 an dieser Stelle noch nicht gelistet, da zurzeit der Abfrage bisher nur eine Neuerscheinung für 2013 gelistet war.

\section{GLIEDERUNG DER DARSTELLUNG:}

siehe Abbildung; beginnend mit 2001, dem Beginn des Gentechnologieberichtes

\section{BERECHNUNGSHÄUFIGKEIT:}

jährlich

\section{AUSSAGEFÄHIGKEIT:}

Der Indikator dokumentiert die publizistische Auseinandersetzung mit dem Thema Gentherapie anhand von einschlägigen Buchpublikationen. Die interessierte Öffentlichkeit kann sich auf diesem Weg weiterführend über das Forschungsfeld informieren.

Abbildung 21: Neuerscheinungen zum Thema Gentherapie

30

25

20

15

10

5

0
30

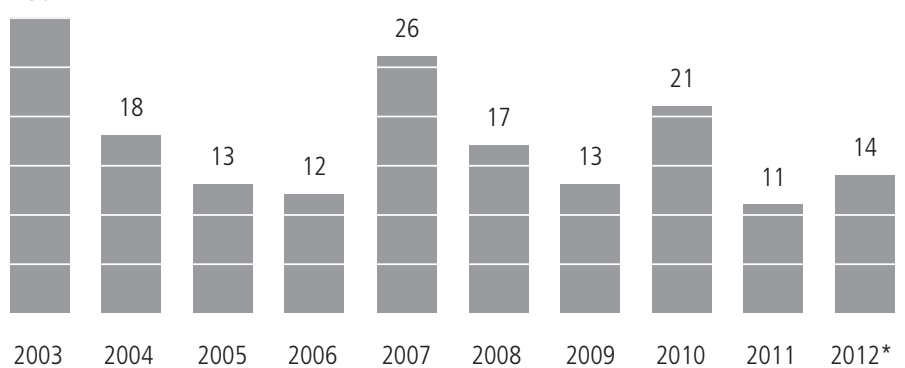

* Stand Juni 2013; Quelle: siehe IndikatorenblattGT-16 956-210, am 26.04.2023, 13:17:31 
Laufende Nr:: GT-17

Problemfeld: Forschungsstandort Deutschland

\section{INDIKATOR: DISSERTATIONEN ZUM THEMA GENTHERAPIE}

\section{DATENQUELLE:}

Online-Katalog der Deutschen Nationalbibliothek. Unter:

https://portal.dnb.de

Zugriff: zuletzt Juni 2013, Stand: k. A.

\section{VERFÜGBARKEIT DER DATEN:}

öffentlich

\section{ABGRENZUNG DER BERECHNUNGSGRÖSSEN:}

Die Nationalbibliothek (DNB) ist bundesunmittelbare Anstalt des öffentlichen Rechts; ihre Aufgabe ist die Archivierung und bibliografische Erfassung in Deutschland veröffentlichter Medienwerke. Die Nationalbibliothek sammelt entsprechend auch veröffentlichte Hochschulschriften wie Dissertationen und Habilitationen. Sie ist nach eigenen Angaben die vollständigste Sammelstelle für deutsche Dissertationen, die als gedruckte Ausgaben, in Verlagen oder als Netzpublikation, DissOnline und open access über den Server der jeweiligen Universität erscheinen. Die Online-Versionen werden erst seit 1998 neben den üblichen Printformen archiviert.

Für die Recherche relevanter Publikationen wurde im Online-Katalog der Deutschen Nationalbibliothek (DNB) über den Reiter "Einfache Suche" im "Gesamten Bestand" nach den "Materialarten" = Blindendrucke, Bücher und Mikroformen mit den Stichworten "Gentherap*"und "gene* therapy" gezielt nach Dissertationen mit gentherapeutischen Bezug innerhalb der Hochschulschriftensammlung ab 2001 gesucht (woe $={ }_{\text {"Gentherap* " OR woe }={ }_{\text {" }} \text { gene }}$ " therapy" AND hss $=-$ diss AND jhr=2001-2013). Datenbank-bedingte Fehlerquellen wurden korrigiert (z. B. Doppellistungen von Buch und Online-Ressource). Die Dissertationen sind jeweils dem im DNB-Katalog aufgeführten Erscheinungsjahr zugeordnet. Die Erhebung ist Stand Juni 2013 und dokumentiert aufgrund der zeitlich verzögerten Meldungen bzw. Listungen bei der DNB nicht den abschließenden Stand für das Jahr 2012*; aufgrund dessen ist auch das Jahr 2013 an dieser Stelle noch nicht gelistet, da zurzeit der Abfrage bisher keine Dissertation für 2013 gelistet war.

\section{GLIEDERUNG DER DARSTELLUNG:}

siehe Abbildung; beginnend mit 2001, dem Beginn des Gentechnologieberichtes

\section{BERECHNUNGSHÄUFIGKEIT:}

jährlich

\section{AUSSAGEFÄHIGKEIT:}

Anhand der veröffentlichten Dissertationen können Forschungsaktivitäten im Gebiet der Gentherapie in Deutschland auf der Ebene der Nachwuchswissenschaftlerinnen und -wissenschaftler aufgezeigt werden. Allerdings ist hier der Umfang an Promotionsstudierenden in Deutschland über die Jahre im Blick zu behalten. Es muss außerdem berücksichtigt werden, dass die Deutsche Nationalbibliothek die mit den einzelnen Dissertationen erlangten Doktorgrade und die dahinterstehenden Disziplinen (Naturwissenschaften, Medizin, Geisteswissenschaften usw.) nicht erfasst. 
Abbildung 22: Anzahl der Dissertationen zum Thema Gentherapie in Deutschland

45

40

35

30

25

20

15

10

5

0
42

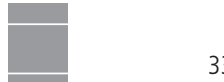

33
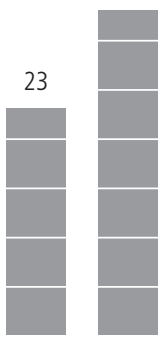

20052006
30

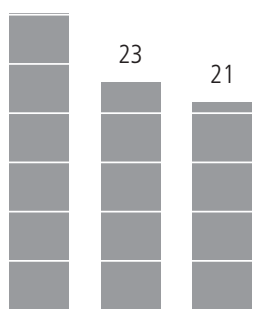

$2007 \quad 2008$
32

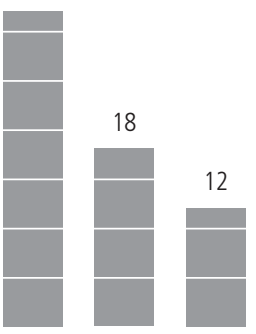

$201020112012^{*}$

* Stand Juni 2013; Quelle: siehe Indikatorenblatt GT-17. 
Laufende Nr:: GT-18

Problemfeld: Öffentliche Wahrnehmung

\section{INDIKATOR: INTERNETPRÄSENZ ZUM THEMA GENTHERAPIE}

\section{DATENQUELLE:}

Google - Suchmaschine. Unter:

www.google.de

Zugriff: zuletzt Juni 2013, Stand: 30.06.2013.

\section{VERFÜGBARKEIT DER DATEN:}

öffentlich

\section{ABGRENZUNG DER BERECHNUNGSGRÖSSEN:}

Für die Recherche wurde das Stichwort "Gentherapie" mit der Suchmaschine "google" gesucht; diese Suchmaschine stellt das am häufigsten in Deutschland genutzte Portal für die Online-Recherche dar. Es werden monatlich die Anzahl an gefundenen Webseiten gemittelt; es erfolgt keine weiterführende qualitative Auswertung der Suchergebnisse. Die Datenerhebung erfolgt seit April 2011. Es muss darauf hingewiesen werden, dass der Internetauftritt der Suchmaschine ständig weiterentwickelt wird und dadurch bedingte Abweichungen zwischen den einzelnen Monaten möglich sind.

\section{GLIEDERUNG DER DARSTELLUNG:}

jährliches Mittel

\section{BERECHNUNGSHÄUFIGKEIT:}

monatlich

\section{AUSSAGEFÄHIGKEIT:}

Der Indikator dokumentiert die öffentliche Präsenz und zugleich Auseinandersetzung mit dem Thema Gentherapie anhand von verfügbaren Webseiten im Internet. Die interessierte Öffentlichkeit kann sich auf diesem Weg weiterführend über das Forschungsfeld informieren. Es ist allerdings möglich, dass die von der Suchmaschine vorgeschlagenen Webseiten sich nicht ausschließlich mit relevanter Forschung befassen, sondern dass Gentherapie nur als randständiges Thema auftritt. Außerdem ist die Qualität der online präsentierten Informationen nicht unmittelbar einschätzbar.

Abbildung 23: Trefferanzahl bei der Stichwortsuche unter Google

330.000

320.000

310.000

300.000

290.000

280.000

270.000

260.000

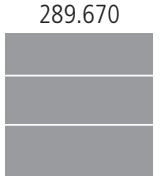

Mittelwert 2011

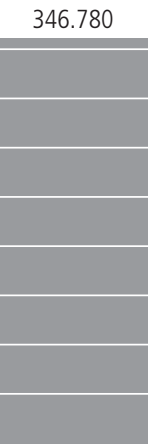

Mittelwert 2012

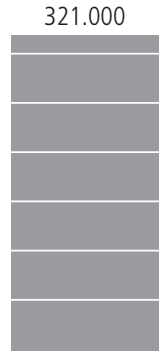

Mittelwert 2013*

* Stand Juni 2013; Quelle: siehe Indikatorenblatt, GD-16.3845246956-210, am 26.04.2023, 13:17:31 
Laufende Nr:: GT-19

Problemfeld: Öffentliche Wahrnehmung

\section{INDIKATOR: MEDIALE PRÄSENZ ZUM THEMA GENTHERAPIE}

\section{DATENQUELLE:}

Frankfurter Allgemeine Zeitung. Unter: http://fazarchiv.faz.net/

Süddeutsche Zeitung. Unter: http://archiv.sueddeutsche.apa.at

Die Zeit. Unter: www.zeit.de

Der Spiegel. Unter: www.spiegel.de/suche

Zugriff: zuletzt Oktober 2013, Stand der Daten: 30.10.2013.

\section{VERFÜGBARKEIT DER DATEN:}

öffentlich

\section{ABGRENZUNG DER BERECHNUNGSGRÖSSEN:}

Für die Recherche relevanter deutscher Presseartikel wurde das Stichwort "Gentherapie" in den online verfügbaren Archiven der ausgewählten überregionalen Zeitungen und Zeitschriften im Volltext gesucht. Berücksichtigt wurden online- und print-erschienene Presseartikel sowie Artikel in Sonderheften. Es wurde keine weiterführende qualitative Filterung der Suchergebnisse vorgenommen. Aufgrund der Volltextsuche ist es möglich, dass die Beiträge sich nicht ausschließlich mit relevanter Forschung befassen, sondern das Gentherapie eines unter mehreren Themen ist.

\section{GLIEDERUNG DER DARSTELLUNG:}

siehe Abbildung; beginnend mit 2001, dem Beginn des Gentechnologieberichtes

\section{BERECHNUNGSHÄUFIGKEIT:}

jährlich

\section{AUSSAGEFÄHIGKEIT:}

Der Indikator dokumentiert die öffentliche Berichterstattung zum Thema im Zeitraum von 2001 bis Mitte 2013 anhand von Publikationen in ausgewählten überregionalen Print- und Onlinemedien. Diese erreichen eine Vielzahl an Menschen in ganz Deutschland. Die Öffentlichkeit wird auf diesem Weg über dieses Forschungsfeld informiert und in ihrer Meinungsbildung beeinflusst. 
Abbildung 24: Presseartikel zum Thema Gentherapie in ausgewählten überregionalen Print-und Online Medien

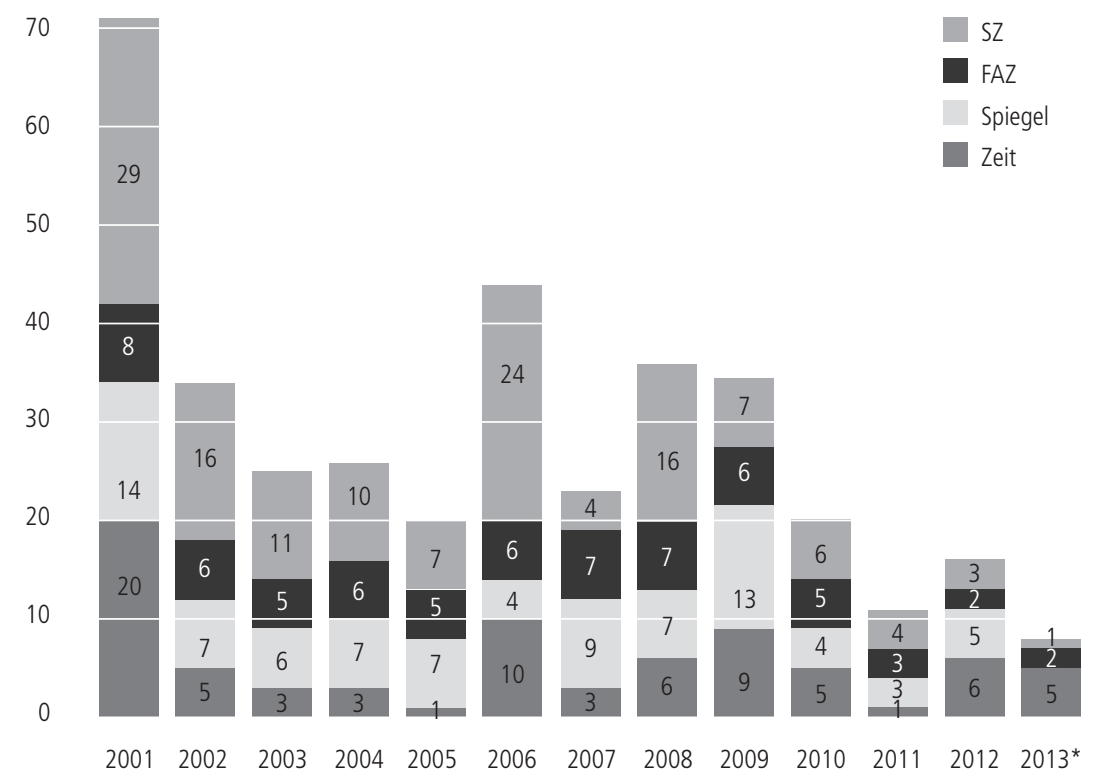

Jeweils aktualisierte Daten; Unterschiede zu früheren Veröffentlichungen möglich.

* Stand Oktober 2013; Quelle: siehe Indikatorenblatt GT-19. 
Laufende Nr.: GT-20

Problemfeld: Forschungsstandort Deutschland

\section{INDIKATOR: TEILNEHMENDE DER FACHGESELLSCHAFTLICHEN JAHRESTAGUNGEN}

\section{DATENQUELLE:}

Deutsche Gesellschaft für Gentherapie e. V.

\section{VERFÜGBARKEIT DER DATEN:}

eigene Recherche; die Zahlen wurden freundlicherweise zur Verfügung gestellt von der Deutschen Gesellschaft für Gentherapie e. V. (Hildegard Büning, Präsidentin) und den Kongresspräsidenten für die aufgeführten Jahre: Wolfgang Uckert, Christopher Baum, Manfred Ogris, Manuel Grez und Boris Fehse.

Stand der Daten: August 2013.

\section{ABGRENZUNG DER BERECHNUNGSGRÖSSEN:}

Die Deutsche Gesellschaft für Gentherapie e. V. (DG-GT) entstand 1994 als Vereinigung von Ärztinnen und Ärzten sowie Naturwissenschaftlerinnen und -wissenschaftlern, die sich mit Problemen der klinischen und experimentellen Gentherapie beschäftigen; 1995 ging daraus ein eingetragener Verein hervor. Die DG-GT ist die deutsche Fachgesellschaft, die Grundlagenwissenschaftlerinnen und -wissenschaftler sowie klinisch Tätige vereinigt, die sich mit den verschiedensten Teilbereichen der Entwicklung von Vektoren, von Gentransfertechniken, von gentherapeutischen Behandlungsstrategien sowie ihrer Umsetzung in die Klinik befassen.

Die Gesellschaft veranstaltet in der Regel jährlich ihre Jahrestagung an wechselnden Orten; die Daten wurden uns freundlicherweise ab 2008 zur Verfügung gestellt; prinzipiell ist eine jährliche Fortschreibung möglich.

\section{GLIEDERUNG DER DARSTELLUNG:}

siehe Abbildung

\section{BERECHNUNGSHÄUFIGKEIT:}

nach Jahren

\section{AUSSAGEFÄHIGKEIT:}

Der Indikator gibt einen Eindruck über Größe und Aktivität der Fachgesellschaft bzw. der Aktiven im Feld der Gentherapie in Deutschland. Er charakterisiert damit unmittelbar den Forschungsstandort Deutschland auf diesem Gebiet. Die Zahlen für die Jahre 2008, 2010 sowie 2013 sind unmittelbar vergleichbar. 
Abbildung 25: Teilnehmerzahlen der fachgesellschaftlichen Jahrestagungen

700

600

500

400

300

200

100

0
653

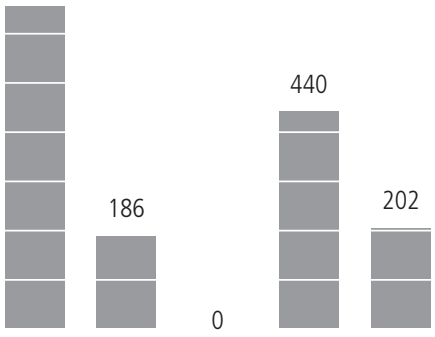

$20082009 * 20102011^{* *} 2012^{* * *} 2013$

* Gemeinschaftsveranstaltung der DG-GT mit der European Society of Gene and Cell Therapy (ESGCT, 565 der 653 Teilnehmende waren für beide Meetings registriert)

** Wechsel vom Herbsttermin 2010 auf Frühjahrstermin (ab 2012), um Kollision mit ESGCT Meeting zu vermeiden *** Gemeinschaftsveranstaltung der DG-GT mit der Stiftung Hämotherapie-Forschung und dem neu gegründeten LOEWE Zentrum für Zell- und Gentherapie Frankfurt a.M.

Quelle: siehe Indikatorenblatt GT-20. 


\subsection{Zusammenfassung}

Die klinische Gentherapie hat sich in den letzten Jahren weitgehend unbemerkt von der Öffentlichkeit vergleichsweise rasant entwickelt. Große Fortschritte wurden bei der Behandlung monogen verursachter Erbkrankheiten (Immundefizienzen, Hämophilie, Blindheit, Stoffwechselerkrankungen) erzielt, für die oft keine oder nur sehr riskante Therapiealternativen existieren. Auch bei der maßstabmäßig bedeutsameren Gentherapie von Krebserkrankungen wurden bemerkenswerte Fortschritte berichtet. Dies betrifft sowohl die direkte Eliminierung maligner Zellen, zum Beispiel mithilfe onkolytischer Viren, als auch die adoptive Immuntherapie mit genetisch modifizierten Lymphozyten. Auf allen Gebieten laufen internationale, oft multizentrische klinische Studien der Phasen II und III, die die Effizienz der Gentherapie analysieren, oft bereits in sogenannten Blindstudien im direkten Vergleich mit bisherigen Optionen (so vorhanden). ${ }^{70}$ Als deutliches Zeichen für die klinischen Erfolge der Gentherapie kann auch der (Wieder-)Einstieg großer Pharmafirmen in das Feld angesehen werden.

In Bezug auf die Behandlung monokausaler Erbkrankheiten hat Europa (Italien, Frankreich, Großbritannien) seine Spitzenposition weitgehend verteidigt. Deutsche Wissenschaftlerinnen und Wissenschaftler sind in internationalen Konsortien wie dem TAGTC und im Rahmen der Sicherheitsanalyse internationaler Studien sehr aktiv und leisten weiterhin wichtige Beiträge, beispielsweise in der Vektorentwicklung und der Sicherheitsforschung. Hinsichtlich der Durchführung eigener klinischer Studien kam es in den letzten Jahren dagegen zu einem Stillstand (siehe Kapitel 6.5.2, GT-10). Obwohl deutsche Teams auch in den letzten Jahren, nicht zuletzt im Rahmen großer Forschungsverbünde, signifikante Beiträge in der Grundlagen- und translationalen Forschung geleistet haben, gelingt kaum die Umsetzung in klinische Studien. In der klinischen Krebsgentherapie liegt die Führungsrolle in der westlichen Welt deutlich in den USA. Durch den Einstieg großer internationaler Pharmafirmen sowohl im Bereich der Immuntherapie als auch der Onkolyse zeichnet sich hier eine deutliche Beschleunigung bei der klinischen Umsetzung gentherapeutischer Ansätze im breiten Maßstab ab. Deutschland droht bei dieser Entwicklung den Anschluss zu verlieren.

Es lässt sich allerdings konstatieren, dass Deutschland seine führende Rolle im Bereich der Gentherapieforschung im Wesentlichen halten konnte. In Bezug auf die Publikationsleistungen lässt sich das aktuell mit dem 3. Platz (hinter den USA und China) nachweisen (GT-3); ein weiteres Indiz ist die stetig steigende Zahl von wissenschaftlichen Einrichtungen und Forschungsgruppen im Bereich der Gentherapie in

70 Klinische Phase-I-Studien dienen der Testung der Anwendbarkeit und Sicherheit, Phase-II-Studien untersuchen die Wirksamkeit, Phase-III-Studien vergleichen die Studienmedikation mit der aktuell angewandten (, State of -the art") Therapie. 
Deutschland (GT-4). Zu dieser Entwicklung hat sicher die Finanzierung mehrerer Verbundprojekte durch nationale Geldgeber wie die Deutsche Forschungsgemeinschaft und das Bundesministerium für Bildung und Forschung entscheidend beigetragen; beide Institutionen fördern auch seit mehreren Jahren zahlreiche Forschungsgruppen, Schwerpunktprogramme etc. (im Einzelnen siehe GT-5).

Gegen den internationalen Trend gibt es dagegen in Deutschland keine echten Fortschritte im Bereich der klinischen Umsetzung, sodass davon auszugehen ist, dass Deutschland seinen dritten Platz hinsichtlich der Anzahl zugelassener Gentherapiestudien (hinter den USA und Großbritannien) in naher Zukunft verlieren wird (GT-7). Auf das zugrunde liegende Problem der limitierten Mittel öffentlicher Geldgeber für solche Studien wurde bereits im Themenband hingewiesen (vgl. Fehse et al., 2011:104); die Unterstützung von Seiten der Industrie ist in Deutschland auch weiterhin marginal. Eine weitere Ursache für die schleppende Translation der immer noch konkurrenzfähigen Gentherapieforschung in klinische Studien ist sicher in den komplexen Regularien zu sehen. Diese führen unter anderem dazu, dass sich die Durchführung akademischer klinischer Studien für die Universitätskliniken extrem aufwendig gestaltet. Zusammen genommen scheinen sich diese Negativfaktoren in zunehmendem Maße zu addieren und so zu einem signifikanten Hemmnis für die Umsetzung der Innovationen der akademischen Gentherapieforschung in Deutschland zu werden.

Die Realisierung von wissenschaftlichen und medizinischen Zielsetzungen ist für die deutsche Gentherapie in der Gesamtsicht demzufolge als heterogen zu beschreiben. Daneben lässt sich der Forschungsstandort Deutschland in der Entwicklung über die letzten Jahre wie folgt zusammenfassen:

- Die Zahl der Publikation in Deutschland ist im Vergleich zu den Vorjahren konstant gestiegen; die Wachstumsrate ist im Vergleich zur gesamteuropäischen Entwicklung überproportional (GT-3).

- Klinische Studien in Deutschland werden allerdings - vor allem im internationalen Vergleich - recht wenig durchgeführt; hier hat die Entwicklung über die letzten Jahre gesehen eher stagniert (GT-7).

- Entsprechend ist die Anzahl der Anträge auf klinische Prüfungen ebenfalls sehr gering und stagnierend (GT-10).

- Die Zahl der auf dem Gebiet arbeitenden Firmen bzw. wissenschaftlichen institutionen (in den Bereichen Forschung und Produkte) wächst hingegen leicht und kontinuierlich. Der weitaus größte Teil der Firmen in diesem Bereich (> 75 \%) beschäftigt 
maximal 50 Mitarbeitende (GT-12), wobei die Anzahl der kommerziell Beschäftigen in diesem Bereich prinzipiell steigt (GT-13).

- Die Zahl der verfertigten Dissertationen ist nach Datenlage bei der Deutschen Nationalbibliothek in den letzten Jahren schwankend, aber grundsätzlich rückläufig (GT-17); gleichwohl gibt es eine konstant bleibende wissenschaftliche Community (GT-20).

Diese Entwicklungen finden ihren Niederschlag auch in der öffentlichen Wahrnehmung beziehungsweise ihren öffentlich wahrnehmbaren Indizien: Die Zahl verfügbarer Bücher zum Thema ist leicht steigend (GT-15); die Zahl der Neuerscheinungen hierbei ist schwankend (GT-16), aber mit durchschnittlich 18 Büchern insofern beachtlich, als dass Buchpublikationen für dieses Feld eher untypisch sind. Die mediale Präsenz des Themas Gentherapie ist in führenden deutschen Printmedien für die letzten zehn Jahre rückläufig (GT-19). ${ }^{71}$ Die Internetpräsenz zum Stichwort „Gentherapie“ ist allerdings über die letzten drei Jahre mit durchschnittlich circa 300.000 Treffern verzeichnet und liefert so eine unüberschaubare Fülle von verschiedensten Informationen zum Thema Gentherapie (GT-18).

\subsection{Literatur}

Abel, T. et al. (2011): When gene vectors are equipped with the correct key, the cell surface can be targeted. In: Pharm Unserer Zeit 40(3): 225-238.

Abi-Ghanem, J. et al. (2013): Engineering of a target site-specific recombinase by a combined evolution- and structure-guided approach. In: Nucleic Acids Res 41(4):2394-2403.

Aiuti, A. et al. (2002): Correction of ADA-SCID by stem cell gene therapy combined with nonmyeloablative conditioning. In: Science 296(5577):2410-2413.

Aiuti, A. et al. (2009): Gene therapy for immunodeficiency due to adenosine deaminase deficiency. In: N Engl J Med 360:447-458.

Aiuti, A. et al. (2013): Lentiviral hematopoietic stem cell gene therapy in patients with WiskottAldrich syndrome. In: Science 341(6148:1233151.

Allers, K. et al. (2011): Evidence for the cure of HIV infection by CCR5 $\Delta 32 / \Delta 32$ stem cell transplantation. In: Blood 117:2791-2799.

Ammar, I. et al. (2012): Retargeting transposon insertions by the adeno-associated virus Rep protein. In: Nucleic Acids Res 40:6693-6712.

Anders, K. et al. (2011): Oncogene-targeting T cells reject large tumors while oncogene inactivation selects escape variants in mouse models of cancer. In: Cancer Cell 20:755-767.

Anderson, W. F. (1972): Genetic therapy. In: Hamilton, M. (eds.): The new genetics and the future of man. Grand Rapids:109-124.

71 Dies hat sicher nicht ausschließlich thematische Gründe, sondern ist auch in der veränderten Rezeption, resp. in der vermehrten Nutzung von anderen Medien begründet. 
Anderson, W. F./Fletcher, J. C. (1980): Sounding boards. Gene therapy in human beings: when is it ethical to begin? In: N Engl J Med 303:1293-1297.

Anliker, B. et al. (2010): Specific gene transfer to neurons, endothelial cells and hematopoietic progenitors with lentiviral vectors. In: Nat Methods 7:929-935.

Arens, A. et al. (2012): Bioinformatic clonality analysis of next-generation sequencing-derived viral vector integration sites. In: Hum Gene Ther Methods 23:111-118.

Avedillo Díez, I. et al. (2011): Development of novel efficient SIN vectors with improved safety features for Wiskott-Aldrich syndrome stem cell based gene therapy. In: Mol Pharm 8:1525-1537.

Bach, P. et al. (2013): Specific elimination of CD133+ tumor cells with targeted oncolytic measles virus. In: Cancer Res 73: 865-874.

Bainbridge, J. W. et al. (2008): Effect of gene therapy on visual function in Leber's congenital amaurosis. In: N Engl J Med 358:2231-2239.

Bartel, M. et al. (2011): Enhancing the clinical potential of AAV vectors by capsid engineering to evade pre-existing immunity. In: Front Microbiol 2:204.

Baum, C. et al. (2011): Concise review: managing genotoxicity in the therapeutic modification of stem cells. In: Stem Cells 29:1479-1484.

Bendle, G. M. et al. (2010): Lethal graft-versus-host disease in mouse models of $\mathrm{T}$ cell receptor gene therapy. In: Nat Med 16:565-570.

Berdien, B. et al. (2013): Influenza virus-specific TCR-transduced T cells as a model for adoptive immunotherapy. In: Hum Vaccin Immunother 9:1205-1216.

Biasco, L. et al. (2011): Integration profile of retroviral vector in gene therapy treated patients is cellspecific according to gene expression and chromatin conformation of target cell. In: EMBO Mol Med 3:89-101.

Biffi, A. et al. (2013): Lentiviral hematopoietic stem cell gene therapy benefits metachromatic leukodystrophy. In: Science 341(6148):1233158.

Bischoff, J. R. et al. (1996): An adenovirus mutant that replicates selectively in p53-deficient human tumour cells. In: Science 274:373-376.

Blaese, R. M. et al. (1995): T lymphocyte-directed gene therapy for ADA-SCID: initial trial results after 4 years. In: Science 270:475-480.

Bodem, J. et al. (2011): Foamy viral nuclear RNA-export is distinct from other retroviruses. In: J Virol 85:2333-2341.

Boztug, K. et al. (2010): Stem-cell gene therapy for the Wiskott-Aldrich syndrome. In: N Engl J Med 363:1918-1927.

Brendel, C. et al. (2012): Physiological regulation of transgene expression by a lentiviral vector containing the A2UCOE linked to a myeloid promoter. In: Gene Ther 19:1018-1029.

Brendel, C. et al. (2013): Human miR223 promoter as a novel myelo-specific promoter for chronic granulomatous disease gene therapy. In: Hum Gene Ther Methods 24:151-159.

Brown, B. D. et al. (2006): Endogenous microRNA regulation suppresses transgene expression in hematopoietic lineages and enables stable gene transfer. In: Nat Med 12:585-591.

Brown, B. D. et al. (2007): A microRNA-regulated lentiviral vector mediates stable correction of hemophilia B mice. In: Blood 110:4144-4152.

Buchholz, F. (2009): Engineering DNA processing enzymes for the postgenomic era. In: Curr Opin Biotechnol 20:383-389. 
Buchholz, F./Hauber, J. (2013): Engineered DNA modifying enzymes: components of a future strategy to cure HIV/AIDS. In: Antiviral Res 97:211-217.

Büning, H. et al. (2010): Do CARs need a driver's license? Adoptive cell therapy with chimeric antigen receptor-redirected T cells has caused serious adverse events. In: Hum Gene Ther 21:1039-1042.

Cartier, N, et al. (2009): Hematopoietic stem cell gene therapy with a lentiviral vector in X-linked adrenoleukodystrophy. In: Science 326:818-823.

Cavazzana-Calvo, M. et al. (2010): Transfusion independence and HMGA2 activation after gene therapy of human $\beta$-thalassaemia. In: Nature 467:318-322.

Chen, S. et al. (2011): Clinical therapeutic effect and biological monitoring of p53 Gene in advanced hepatocellular carcinoma. In: Am J Clin Oncol [Epub ahead of print].

Chen, Z. Y. et al. (2003): Minicircle DNA vectors devoid of bacterial DNA result in persistent and highlevel transgene expression in vivo. In: Mol Ther 8:495-500.

Chmielewski, M. et al. (2012): T cells that target carcinoembryonic antigen eradicate orthotopic pancreatic carcinomas without inducing autoimmune colitis in mice. In: Gastroenterology 143:10951107.

Chmielewski, M. et al. (2013): T cells redirected by a CD3 $\zeta$ chimeric antigen receptor can establish self-antigen-specific tumour protection in the long term. In: Gene Ther 20:177-186.

Cideciyan, A. V. et al. (2008): Human gene therapy for RPE65 isomerase deficiency activates the retinoid cycle of vision but with slow rod kinetics. In: Proc Natl Acad Sci USA 105:15112-15117.

Cideciyan, A. V. et al. (2013): Human retinal gene therapy for Leber congenital amaurosis shows advancing retinal degeneration despite enduring visual improvement. In: Proc Natl Acad Sci USA 110:E517-525.

Cornils, K. et al. (2013): Comparative clonal analysis of reconstitution kinetics after transplantation of hematopoietic stem cells gene marked with a lentiviral SIN or a $\gamma$-retroviral LTR vector. In: Exp Hematol 41:28-38.

Corrigan-Curay, J. et al. (2012): Challenges in vector and trial design using retroviral vectors for longterm gene correction in hematopoietic stem cell gene therapy. In: Mol Ther 20:1084-1094.

Curran, K. J. et al. (2012): Chimeric antigen receptors for T cell immunotherapy: current understanding and future directions. In: J Gene Med 14:405-415.

De Ravin, S. S. et al. (2013): Lentiviral gene transfer for treatment of children $>2$ years old with x-linked severe combined immunodeficiency. In: Mol Ther 21,Suppl. 1:119.

Domasch, S./Fehse, B. (2011): Gentherapie in Deutschland. Eine Einführung. In: Fehse, B./Domasch, S. (Hrsg.): Gentherapie in Deutschland. Eine interdisziplinäre Bestandsaufnahme. Dornburg:31-40.

Domasch, S./Osterheider, A. (2011): Daten zu ausgewählten Indikatoren [zur Gentherapie]. In: Fehse, B./Domasch, S. (Hrsg.): Gentherapie in Deutschland. Eine interdisziplinäre Bestandsaufnahme. Dornburg:257-301.

Donsante, A. et al. (2007): AAV vector integration sites in mouse hepatocellular carcinoma. In: Science 317:477.

Dössinger, G. et al. (2013): MHC multimer-guided and cell culture-independent isolation of functional $\mathrm{T}$ cell receptors from single cells facilitates TCR identification for immunotherapy. In: PLoS One 8:e61384. 
Eager, R. M./Nemunaitis, J. (2011): Clinical development directions in oncolytic viral therapy. In: Cancer Gene Ther 18:305-317.

Ehrhardt, A. et al. (2008): Episomal Vectors for Gene Therapy. In: Current Gene Therapy 8:147-161.

El-Andaloussi, N. et al. (2012): Generation of an adenovirus-parvovirus chimera with enhanced oncolytic potential. In: J Virol 86:10418-10431.

Eshhar, Z. et al. (1993): Specific activation and targeting of cytotoxic lymphocytes through chimeric single chains consisting of antibody-binding domains and the gamma or zeta subunits of the immunoglobulin and T-cell receptors. In: Proc Natl Acad Sci USA 90:720-724.

Fateh-Moghadam, B. (2011): Rechtliche Aspekte der somatischen Gentherapie. In: Fehse, B./Domasch, S. (Hrsg.): Gentherapie in Deutschland. Eine interdisziplinäre Bestandsaufnahme. Dornburg:151-184.

Fehse, B./Domasch, S. (Hrsg.) (2011): Gentherapie in Deutschland. Eine interdisziplinäre Bestandsaufnahme. Dornburg.

Fehse, B. et al. (2011): Stand wissenschaftlicher und medizinischer Entwicklungen. In: Fehse, B./Domasch, S. (Hrsg.): Gentherapie in Deutschland. Eine interdisziplinäre Bestandsaufnahme. Dornburg:41-126.

Frecha, C. et al. (2008): Strategies for targeting lentiviral vectors. In: Curr Gene Ther 8:449-460.

Freese, E. (1972): Prospects of gene therapy. In: Science 175:1024-1025.

Friedmann, T. (1992): A brief history of gene therapy. In: Nat Genet 2:93-98.

Friedmann, T./Roblin, R. (1972): Gene therapy for human genetic disease? In: Science 175:949-955.

Friedmann-Morvinski, D. et al. (2005): Redirected primary T cells harboring a chimeric receptor require costimulation for their antigen-specific activation. In: Blood 105(8):3087-3093.

Friedrich, K. et al. (2013): DARPin-targeting of measles virus: unique bispecificity, effective oncolysis, and enhanced safety. In: Mol Ther 21:849-859.

Fuchs, M. (2011): Forschungsethische Aspekte der Gentherapie. In: Fehse, B./Domasch, S. (Hrsg.): Gentherapie in Deutschland. Eine interdisziplinäre Bestandsaufnahme. Dornburg:185-208.

Funke, S. et al. (2008): Targeted cell entry of lentiviral vectors. Mol Ther 16:1427-1436.

Funke, S. et al. (2009): Pseudotyping lentiviral vectors with the wild-type measles virus glycoproteins improves titer and selectivity. In: Gene Ther 16:700-705.

Gabriel, R. et al. (2009): Comprehensive genomic access to vector integration in clinical gene therapy. In: Nat Med 15:1431-1436.

Gabriel, R. et al. (2011): An unbiased genome-wide analysis of zinc-finger nuclease specificity. In: Nat Biotechnol 29:816-823.

Galla, M. et al. (2011): Avoiding cytotoxicity of transposases by dose-controlled mRNA delivery. In: Nucleic Acids Res 39:7147-7160.

Gaspar, H. B. et al. (2004): Gene therapy of x-linked severe combined immunodeficiency by use of a pseudotyped gammaretroviral vector. In: Lancet 364:2181-2187.

Gentschev, I. et al. (2012): Preclinical evaluation of oncolytic vaccinia virus for therapy of canine soft tissue sarcoma. In: PLoS One 7:e37239.

Girod, A. et al. (1999): Genetic capsid modifications allow efficient re-targeting of adeno- associated virus type 2. In: Nat Med 5:1052-1056.

Grabundzija, I. et al. (2010): Comparative analysis of transposable element vector systems in human cells. In: Mol Ther 18:1200-1209. 
Grabundzija, I. et al. (2013): Sleeping beauty transposon-based system for cellular reprogramming and targeted gene insertion in induced pluripotent stem cells. In: Nucleic Acids Res 41:1829-1847.

Grupp, S. A. et al. (2013): Chimeric antigen receptor-modified T cells for acute lymphoid leukemia. In: N Engl J Med 368:1509-1518.

Haase, R. et al. (2010): pEPito: a significantly improved non-viral expression vector for mammalian cell. In: BMC Biotechnology 10:20.

Haase, R. et al. (2013): Generation of a tumor- and tissue-specific episomal non-viral vector system. In: BMC Biotechnol 13:49.

Hacein-Bey-Abina, S. et al. (2002): Sustained correction of X-linked severe combined immunodeficiency by ex vivo gene therapy. In: N Engl J Med 346:1185-1193.

Hacein-Bey-Abina, S. et al. (2008): Insertional oncogenesis in 4 patients after retrovirus-mediated gene therapy of SCID-X1. In: J Clin Invest 118:3132-3142.

Hacein-Bey-Abina, S. et al. (2013a): Lentiviral vector-based gene therapy for Wiskott-Aldrich syndrome: preliminary results from the French Center. In: Mol Ther 21, Suppl. 1:117.

Hacein-Bey-Abina, S. et al. (2013b): Comparison of integration site profiles between SCID-X1 gene therapy trials using gammaretroviral vectors with intact or deleted (SIN) LTRs. In: Mol Ther 21, Suppl.1:119.

Händel, E. M. et al. (2012): Versatile and efficient genome editing in human cells by combining zincfinger nucleases with adeno-associated viral vectors. In: Hum Gene Ther 23:321-329.

Händel, E. M./Cathomen, T. (2011): Zinc-Finger Nuclease Based Genome Surgery: It's all About Specificity. In: Curr Gene Ther 11:28-37.

Hausl, M. A. et al. (2010): Hyperactive sleeping beauty transposase enables persistent phenotypic correction in mice and a canine model for hemophilia B. In: Mol Ther 18:1896-1906.

Heckl, D. et al. (2012): Lentiviral vector induced insertional haploinsufficiency of Ebf1 causes murine leukemia. In: Mol Ther 20:1187-1195.

Heinrich, T. et al. (2013): Mature T-cell lymphomagenesis induced by retroviral insertional activation of Janus kinase 1. In: Mol Ther 21:1160-1168.

Ho, Y. P. et al. (2012): A small-molecule-controlled system for efficient pseudotyping of prototype foamy virus vectors. In: Mol Ther 20:1167-1176.

Holkers, M. et al. (2013): Differential integrity of TALE nuclease genes following adenoviral and lentiviral vector gene transfer into human cells. In: Nucleic Acids Res 41:e63.

Hombach, A. A. et al. (2013): Adoptive immunotherapy with redirected T cells produces CCR7- cells that are trapped in the periphery and benefit from combined CD28-OX40 costimulation. In: Hum Gene Ther 24:259-269.

Howe, S. J. et al. (2008): Insertional mutagenesis combined with acquired somatic mutations causes leukemogenesis following gene therapy of SCID-X1 patients. In: J Clin Invest 118:3143-3150.

Hucho, F. et al. (2005): Gentechnologiebericht. Analyse einer Hochtechnologie in Deutschland. München.

Hucho, F. et al. (2008): Gentherapie in Deutschland. Eine interdisziplinäre Bestandsaufnahme. Dornburg.

Hütter, G. et al. (2009): Long-term control of HIV by CCR5 Delta32/Delta32 stem-cell transplantation. In: N Engl J Med 360:692-698. 
Hütter, S. et al. (2013): Prototype foamy virus protease activity is essential for intraparticle reverse transcription initiation but not absolutely required for uncoating upon host cell entry. In: J Virol 87:3163-3176.

Ivics, Z. et al. (1997): Molecular reconstruction of Sleeping Beauty, a Tc1-like transposon from fish, and its transposition in human cells. In: Cell 91:501-510.

Ivics, Z. et al. (2009): Transposon-mediated genome manipulation in vertebrates. In: Nat Methods $6: 415-422$.

Jacobson, S. G. et al. (2012): Gene therapy for leber congenital amaurosis caused by RPE65 mutations: safety and efficacy in 15 children and adults followed up to 3 years. In: Arch Ophthalmol 130:9-24.

Jager, L. et al. (2009): A rapid protocol for construction and production of helper-dependent adenoviral vectors. In: Nature Protocols 4:547-564.

Jaguva Vasudevan, A. A. et al. (2013): Prototype foamy virus bet impairs the dimerization and cytosolic solubility of human APOBEC3G. In: J Virol 87(16):9030-9040.

Johnson, L. A. et al. (2009): Gene therapy with human and mouse T-cell receptors mediates cancer regression and targets normal tissues expressing cognate antigen. In: Blood 114:535-546.

Jorritsma, A. et al. (2011): Prospects and limitations of T cell receptor gene therapy. In: Curr Gene Ther 11:276-287.

Kaeppel, C. et al. (2013) A largely random AAV integration profile after LPLD gene therapy. In: Nat Med 19:889-891.

Kalos, M. et al. (2011): T cells with chimeric antigen receptors have potent antitumor effects and can establish memory in patients with advanced leukemia. In: Sci Transl Med 3:95ra73.

Kammertoens, T. et al. (2005): Immunotherapy: target the stroma to hit the tumor. In: Trends Mol Med 11(5):225-231.

Karimova, M. et al. (2013): Vika/vox, a novel efficient and specific Cre/loxP-like site-specific recombination system. In: Nucleic Acids Res 41:e37.

Kasper, J. C. et al. (2011): The establishment of an up-scaled micro-mixer method allows the standardized and reproducible preparation of well-defined plasmid/LPEI polyplexes. In: Eur J Pharm Biopharm 77:182-185.

Kaufmann, J. K./Nettelbeck, D. M. (2012): Virus chimeras for gene therapy, vaccination, and oncolysis: adenoviruses and beyond. In: Trends Mol Med 18:365-376.

Kaufmann, K. B. et al. (2013): Alpharetroviral vector-mediated gene therapy for X-CGD: functional correction and lack of aberrant splicing. In: Mol Ther 21:648-661.

Ketzer, P. et al. (2012): Synthetic riboswitches for external regulation of genes transferred by replication-deficient and oncolytic adenoviruses. In: Nucleic Acids Res 40:e167.

Kieback, E. et al. (2008): A safeguard eliminates T cell receptor gene-modified autoreactive T cells after adoptive transfer. In: Proc Natl Acad Sci USA 105:623-628.

Kiprianova, I. et al. (2011): Regression of glioma in rat models by intranasal application of parvovirus h-1. In: Clin Cancer Res 17:5333-5342.

Kirn, D. H. (2011): Redemption for the field of oncolytic virotherapy. In: Mol Ther 19:627-628.

Klutz, K. et al. (2011): Epidermal growth factor receptor-targeted (131)I-therapy of liver cancer following systemic delivery of the sodium iodide symporter gene. In: Mol Ther 19:676-85. 
Kneissl, S. et al. (2012): Measles virus glycoprotein-based lentiviral targeting vectors that avoid neutralizing antibodies. In: PLoS One 7:e466673.

Kochanek, S. et al. (1996): A new adenoviral vector: replacement of all viral coding sequences with 28 $\mathrm{kb}$ of DNA independently expressing both full-length dystrophin and beta-galactosidase. In: Proc Natl Acad Sci USA 93:5731-5736.

Kochanek, S. et al. (2001): High-capacity 'gutless' adenoviral vectors. In: Curr Opin Mol Ther 3:454463.

Kochenderfer, J. N. et al. (2012): B-cell depletion and remissions of malignancy along with cytokineassociated toxicity in a clinical trial of anti-CD19 chimeric-antigen-receptor-transduced T cells. In: Blood 119:2709-2720.

Kofler, D. M. et al. (2011): CD28 costimulation impairs the efficacy of a redirected t-cell antitumor attack in the presence of regulatory t cells which can be overcome by preventing Lck activation. In: Mol Ther 19:760-767.

Kohn, D. B. (2010): Update on gene therapy for immunodeficiencies. In: Clin Immunol 135:247-254.

Kopp, F. et al. (2013): De-targeting by miR-143 decreases unwanted transgene expression in nontumorigenic cells. In: Gene Ther 20(11):1104-1109.

Krebs, K. et al. (2013): T cells expressing a chimeric antigen receptor that binds hepatitis b virus envelope proteins control virus replication in mice. In: Gastroenterology 145:456-465.

Kustikova, O. et al. (2005): Clonal dominance of hematopoietic stem cells triggered by retroviral gene marking. In: Science 308:1171-1174.

Laakkonen, J. P. et al. (2012): Transcellular targeting of fiber- and hexon-modified adenovirus vectors across the brain microvascular endothelial cells in vitro. In: PLoS One 7:e45977.

Lacroix, J. et al. (2013): Oncolytic effects of parvovirus H-1 in medulloblastoma are associated with repression of master regulators of early neurogenesis. In: Int J Cancer 134(3):703-716.

Lagisetty, K. H./Morgan, R. A. (2012): Cancer therapy with genetically-modified T cells for the treatment of melanoma. In: J Gene Med 14:400-404.

Lamers, C. H. et al. (2006): Treatment of metastatic renal cell carcinoma with autologous T-lymphocytes genetically retargeted against carbonic anhydrase IX: first clinical experience. In: J Clin Oncol 24:e20-22.

Leisegang, M. et al. (2010): MHC-restricted fratricide of human lymphocytes expressing survivinspecific transgenic T cell receptors. In: J Clin Invest 120:3869-3877.

Li, Z. et al. (2002): Murine leukemia induced by retroviral gene marking. In: Science 296:497.

Liang, M. (2012): Clinical development of oncolytic viruses in China. In: Curr Pharm Biotechnol 13:1852-1857.

Lieber, A. et al. (1996): Recombinant adenoviruses with large deletions generated by Cre-mediated excision exhibit different biological properties compared with first-generation vectors in vitro and in vivo. In: J Virol 70:8944-8960.

Lindemann, D./Rethwilm, A. (2011): Foamy virus biology and its application for vector development. In: Viruses 3:561-585.

Liu, T. C. et al. (2007): Clinical trial results with oncolytic virotherapy: a century of promise, a decade of progress. In: Nat Clin Pract Oncol 4:101-117.

Liu, Y./Deisseroth, A. (2006): Tumor vascular targeting therapy with viral vectors. In: Blood 107:30273033. 
Ma, G. et al. (2009): Gene medicine for cancer treatment: commercially available medicine and accumulated clinical data in China. In: Drug Des Devel Ther 2:115-122.

Maetzig, T. et al. (2011): Polyclonal fluctuation of lentiviral vector-transduced and expanded murine hematopoietic stem cells. In: Blood 117:3053-3064.

Maguire, A. M. et al. (2008): Safety and efficacy of gene transfer for Leber's congenital amaurosis. In: N Engl J Med 2008(358):2240-2248.

Maliar, A. et al. (2012): Redirected T cells that target pancreatic adenocarcinoma antigens eliminate tumors and metastases in mice. In: Gastroenterology 143:1375-1384.

Manno, C. S. et al. (2006): Successful transduction of liver in hemophilia by AAV-factor IX and limitations imposed by the host immune response. In: Nat Med 12:342-347.

Mariyanna, L. et al. (2012): Excision of HIV-1 proviral DNA by recombinant cell permeable tre-recombinase. In: PLoS One 7:e31576.

Märsch, S. et al. (2010): A novel directed evolution method to enhance cell-type specificity of adenoassociated virus vectors. In: Comb Chem High Throughput Screen 13:807-182.

Mátés, L. et al. (2009): Molecular evolution of a novel hyperactive sleeping beauty transposase enables robust stable gene transfer in vertebrates. In: Nat Genet 41:753-761.

Matthes, D. et al. (2011): Basic residues in the foamy virus Gag protein. In: J Virol 85:3986-3995.

Michelfelder, S. et al. (2011): Peptide ligands incorporated into the threefold spike capsid domain to re-direct gene transduction of AAV8 and AAV9 in vivo. In: PLoS One 6:e23101.

Miletic, H. et al. (2007): Bystander killing of malignant glioma by bone marrow-derived tumor-Infiltrating progenitor cells expressing a suicide gene. In: Mol Ther 15(7):1373-1381.

Mingozzi, F. et al. (2007): CD8(+) T-cell responses to adeno-associated virus capsid in humans. In: Nat Med 13(4):419-422.

Mitchell, R. S. et al. (2004): Retroviral DNA integration: ASLV, HIV, and MLV show distinct target site preferences. In: PLoS Biol 2:E234.

Mock, U. et al. (2012): Efficient lentiviral transduction and transgene expression in primary human B cells. In: Hum Gene Ther Methods 23:408-415.

Modlich, U. et al. (2005): Leukemias following retroviral transfer of multidrug resistance 1 (MDR1) are driven by combinatorial insertional mutagenesis. In: Blood 105:4235-4246.

Modlich, U. et al. (2006): Cell culture assays reveal the importance of retroviral vector design for insertional genotoxicity. In: Blood 108:2545-2453.

Modlich, U. et al. (2008): Leukemia induction after a single retroviral vector insertion in Evi1 or Prdm16. In: Leukemia 22:1519-1528.

Modlich, U. et al. (2009): Insertional transformation of hematopoietic cells by self-inactivating lentiviral and gammaretroviral vectors. In: Mol Ther 17:1919-1928.

Moreno-Carranza, B. et al. (2009): Transgene optimization significantly improves SIN vector titers, gp91phox expression and reconstitution of superoxide production in X-CGD cells. In: Gene Ther 16:111-118.

Morgan, R. A. et al. (2006): Cancer regression in patients after transfer of genetically engineered lymphocytes. In: Science 314:126-129.

Morgan, R. A. et al. (2010): Case report of a serious adverse event following the administration of T cells transduced with a chimeric antigen receptor recognizing ERBB2. In: Mol Ther 18:843-851.

Morgan, R. A. et al. (2013): Cancer regression and neurological toxicity following anti-MAGE-A3 TCR gene therapy. In: J Immunother 36:133-151. 
Mueller, K. et al. (2012): Protective capacity of virus-specific T cell receptor-transduced CD8 T cells in vivo. In: J Virol 86:10866-10869.

Mühlebach, M. D. et al. (2010): Liver cancer protease activity profiles support therapeutic options with matrix metalloproteinase-activatable oncolytic measles virus. In: Cancer Res 70:7620-7629.

Muik, A. et al. (2011): Pseudotyping vesicular stomatitis virus with lymphocytic choriomeningitis virus glycoproteins enhances infectivity for glioma cells and minimizes neurotropism. In: J Virol 85:5679-5684.

Muik, A. et al. (2012): Semireplication-competent vesicular stomatitis virus as a novel platform for oncolytic virotherapy. In: J Mol Med (Berl) 90:959-970.

Müller, O. J. et al. (2003): Random peptide libraries displayed on adeno-associated virus to select for targeted gene therapy vectors. In: Nature Biotechnology 21:1040-1046.

Müller-Röber, B. et al. (2009): Zweiter Gentechnologiebericht. Analyse einer Hochtechnologie in Deutschland. Dornburg.

Müllers, E. et al. (2011): Prototype foamy virus gag nuclear localization: a novel pathway among retroviruses. In: J Virol 85:9276-9285.

Münch, R. C. et al. (2011): DARPins: an efficient targeting domain for lentiviral vectors. In: Mol Ther 19:686-693

Münch, R. C. et al. (2013): Displaying high-affinity ligands on adeno-associated viral vectors enables tumor cell-specific and safe gene transfer. In: Mol Ther 21:109-118.

Mussolino, C. et al. (2011): A novel TALE nuclease scaffold enables high genome editing activity in combination with low toxicity. In: Nucleic Acids Res 39:9283-9293.

Mussolino, C./Cathomen, T. (2011): On target? Tracing zinc-finger-nuclease specificity. In: Nat Methods 8:725-726.

Muul, L. M. et al. (2003): Persistence and expression of the adenosine deaminase gene for 12 years and immune reaction to gene transfer components: long-term results of the first clinical gene therapy trial. In: Blood 101:2563-2569.

Nathwani, A. C. et al. (2011): Adenovirus-associated virus vector-mediated gene transfer in hemophilia B. In: N Engl J Med 365:2357-2365.

Nauerth, M. et al. (2013): TCR-ligand $k_{\text {off }}$ rate correlates with the protective capacity of antigen-specific CD8+ T cells for adoptive transfer. In: Sci Transl Med 5:192ra87.

Naumer, M. et al. (2012): Development and validation of novel AAV2 random libraries displaying peptides of diverse lengths and at diverse capsid positions. In: Hum Gene Ther 23:492-507.

Newrzela, S. et al. (2008): Resistance of mature T cells to oncogene transformation. In: Blood 112:2278-2286.

Newrzela, S. et al. (2011): Retroviral insertional mutagenesis can contribute to immortalization of mature T lymphocytes. In: Mol Med 17:1223-1232.

Newrzela, S. et al. (2012): T-cell receptor diversity prevents T-cell lymphoma development. In: Leukemia 26:2499-2507.

Nie, Y. et al. (2011): Dual-targeted polyplexes: one step towards a synthetic virus for cancer gene therapy. In: J Control Release 152:127-134.

Niess, H. et al. (2011): Selective targeting of genetically engineered mesenchymal stem cells to tumor stroma microenvironments using tissue-specific suicide gene expression suppresses growth of hepatocellular carcinoma. In: Ann Surg 254:767-774. 
Ogris, M./Wagner, E. (2011): To be targeted: is the magic bullet concept a viable option for synthetic nucleic acid therapeutics? In: Hum Gene Ther 22:799-807.

Ott, M. G. et al. (2006): Correction of x-linked chronic granulomatous disease by gene therapy, augmented by insertional activation of MDS1-EVI1, PRDM16 or SETBP1. In: Nat Med 12:401-409.

Park, T. S. et al. (2011): Treating cancer with genetically engineered T cells. In: Trends Biotechnol 29:550-557.

Parkhurst, M. R. et al. (2011): T cells targeting carcinoembryonic antigen can mediate regression of metastatic colorectal cancer but induce severe transient colitis. In: Mol Ther 19:620-626.

Paruzynski, A. et al. (2010): Genome-wide high-throughput integrome analyses by nrLAM-PCR and next-generation sequencing. In: Nat Protoc 5:1379-1395.

Patel, M. R./Kratzke, R. A. (2013): Oncolytic virus therapy for cancer: the first wave of translational clinical trials. In: Transl Res 161:355-364.

Perabo, L. et al. (2003): In vitro selection of viral vectors with modified tropism: the adeno-associated virus display. In: Molecular Therapy 8:151-157.

Plochmann, K. et al. (2012): Heparan sulfate is an attachment factor for foamy virus entry. In: J Virol 86:10028-10035.

Porter, D. L. et al. (2011): Chimeric antigen receptor-modified T cells in chronic lymphoid leukemia. In: N Engl J Med 365:725-733.

Preuss, E. et al. (2010): A novel, codon-optimised HSVtk(A168H) mutant [TK.007] for suicide gene therapy. In: Hum Gene Ther 21:929-941.

Preuss, E. et al. (2011): Cancer suicide gene therapy with TK.007: superior killing efficiency and bystander effect. In: J Mol Med (Berl) 89:1113-1124.

Prill, J. M. et al. (2011): Modifications of adenovirus hexon allow for either hepatocyte detargeting or targeting with potential evasion from Kupffer cells. In: Mol Ther 19:83-92.

Provasi, E. et al. (2012): Editing T cell specificity towards leukemia by zinc finger nucleases and lentiviral gene transfer. In: Nat Med 18:807-815.

Quirin, C. et al. (2011): Selectivity and efficiency of late transgene expression by transcriptionally targeted oncolytic adenoviruses are dependent on the transgene insertion strategy. In: Hum Gene Ther 22:389-404.

Rahman, S. H. et al. (2013): The nontoxic cell cycle modulator indirubin augments transduction of adeno-associated viral vectors and zinc-finger nuclease-mediated gene targeting. In: Hum Gene Ther 24:67-77.

Rainov, N. G. (2000): A phase III clinical evaluation of herpes simplex virus type 1 thymidine kinase and ganciclovir gene therapy as an adjuvant to surgical resection and radiation in adults with previously untreated glioblastoma multiforme. In: Hum Gene Ther 11:2389-2401.

Ramirez, C. L. et al. (2012): Engineered zinc finger nickases induce homology-directed repair with reduced mutagenic effects. In: Nucleic Acids Res 40:5560-5568.

Raper, S. E. et al. (2003): Fatal systemic inflammatory response syndrome in a ornithine transcarbamylase deficient patient following adenoviral gene transfer. In: Mol Genet Metab 80:148-158.

Rappl, G. et al. (2012): The CD3-zeta chimeric antigen receptor overcomes TCR hypo-responsiveness of human terminal late-stage T cells. In: PLoS One 7:e30713. 
Robbins, P. F. et al. (2011): Tumor regression in patients with metastatic synovial cell sarcoma and melanoma using genetically engineered lymphocytes reactive with NY-ESO-1. In: J Clin Oncol 29:917-924.

Rommelaere, J. et al. (2010): Oncolytic parvoviruses as cancer therapeutics. In: Cytokine Growth Factor Rev 21:185-195.

Rosenberg, S. A. et al. (1990): Gene transfer into humans--immunotherapy of patients with advanced melanoma, using tumor-infiltrating lymphocytes modified by retroviral gene transduction. In: New Engl J Med 323:570-578.

Russell, S. J. et al. (2012): Oncolytic virotherapy. In: Nat Biotechnol 30:658-670.

Rybniker, J. et al. (2012): Incorporation of antigens into viral capsids augments immunogenicity of adeno-associated virus vector-based vaccines. In: J Virol 86:13800-13804.

Santilli, G. et al. (2011): Biochemical correction of X-CGD by a novel chimeric promoter regulating high levels of transgene expression in myeloid cells. In: Mol Ther 19:122-132.

Sarkar, I. et al. (2007): HIV-1 proviral DNA excision using an evolved recombinase. In: Science 316:1912-1915.

Schäfer, A. et al. (2011): Disconnecting the yin and yang relation of epidermal growth factor receptor (EGFR)-mediated delivery: a fully synthetic, EGFR-targeted gene transfer system avoiding receptor activation. Hum Gene Ther 22:1463-1473.

Schäfer, S. et al. (2012): Vaccinia virus-mediated intra-tumoral expression of matrix metalloproteinase 9 enhances oncolysis of PC-3 xenograft tumors. In: BMC Cancer 12:366.

Schaffert, D. (2011): Poly(I:C)-mediated tumor growth suppression in EGF-receptor overexpressing tumors using EGF-polyethylene glycol-linear polyethylenimine as carrier. In: Pharm Res 28:731741.

Schierling, B. (2012): A novel zinc-finger nuclease platform with a sequence-specific cleavage module. In: Nucleic Acids Res 40:2623-2638.

Schleef, M. et al. (2010): Production of non viral DNA vectors. In: Curr Gene Ther 10:487-507.

Schleef, M./Blaesen, M. (2009): Production of plasmid DNA as a pharmaceutical. In: Methods Mol Biol 542:471-495.

Schmidt, M. et al. (2007): High-resolution insertion-site analysis by linear amplification-mediated PCR (LAM-PCR). In: Nat Methods 4:1051-1057.

Schmidt, P. et al. (2011): Eradication of melanomas by targeted elimination of a minor subset of tumor cells. In: Proc Natl Acad Sci USA 108:2474-2479.

Schwarzwaelder, K. et al. (2007): Gammaretrovirus-mediated correction of SCID-X1 is associated with skewed vector integration site distribution in vivo. In: J Clin Invest 117:2241-2249.

Seymour, L. W. (2011): Oncolytic virotherapy: combining first-rate science with an unmet clinical need. In: Hum Gene Ther 22:387-388.

Söllü, C. et al. (2010): Autonomous zinc-finger nuclease pairs for targeted chromosomal deletion. In: Nucleic Acids Res 38:8269-8276.

Spranger, S. et al. (2012): TCR-transgenic lymphocytes specific for HMMR/Rhamm limit tumor outgrowth in vivo. In: Blood 119:3440-3449.

Stauss, H. J./Morris, E. C. (2013): Immunotherapy with gene-modified T cells: limiting side effects provides new challenges. In: Gene Ther 20(11)1029-1032.

Stein, S. et al. (2010): Genomic instability and myelodysplasia with monosomy 7 consequent to EVI1 activation after gene therapy for chronic granulomatous disease. In: Nat Med 16:198-204 
Stein, S. et al. (2013): From bench to bedside: Preclinical evaluation of a SIN gammaretroviral vector for the gene therapy of x-linked chronic granulomatous disease. In: Hum Gene Ther Clin Dev 24(2):86-98.

Stephen, S. L. et al. (2010): Chromosomal integration of adenoviral vector DNA in vivo. In: J Virol. 84:9987-9994.

Stone, D. et a. (2013): Targeted gene disruption to cure HIV. In: Curr Opin HIV AIDS 8:217-223.

Suerth, J. D. et al. (2012): Alpharetroviral self-inactivating vectors: long-term transgene expression in murine hematopoietic cells and low genotoxicity. In: Mol Ther 20:1022-1032.

Suerth, J. D. et al. (2010): Self-inactivating alpharetroviral vectors with a split-packaging design. In: J Virol 84:6626-6635.

Tatum, E. L. (1966): Molecular biology, nucleic acids, and the future of medicine. In: Perspectives in Biology and Medicine. 10(1):19-32. In 2009 republished: Tatum, E. L. (2009): Molecular biology, nucleic acids, and the future of medicine. In: Cellular Ther Transplant 1(4):74-79.

Uhrig, S. et al. (2012): Successful target cell transduction of capsid-engineered rAAV vectors requires clathrin-dependent endocytosis. In: Gene Ther 19:210-218.

Uttenthal, B. J. et al. (2012): Challenges in T cell receptor gene therapy. In: J Gene Med 14:386-399.

van Lunzen, J. et al. (2011): Gene therapy strategies: can we eradicate HIV? In: Curr HIV/AIDS Rep 8:78-84.

Vandenberghe, L. H. et al. (2006): Heparin binding directs activation of T cells against adeno-associated virus serotype 2 capsid. In: Nat Med 12:967-971.

Varadi, K. et al. (2012): Novel random peptide libraries displayed on AAV serotype 9 for selection of endothelial cell-directed gene transfer vectors. In: Gene Ther 19:800-809.

Vetter, A. et al. (2013): Adenoviral vectors coated with PAMAM dendrimer conjugates allow CAR independent virus uptake and targeting to the EGF receptor. In: Mol Pharm 10:606-618.

Voigt, K. et al. (2012): Retargeting sleeping beauty transposon insertions by engineered zinc finger DNA-binding domains. In: Mol Ther 20:1852-1862.

Voigtlander, R. et al. (2013): A novel adenoviral hybrid-vector system carrying a plasmid replicon for safe and efficient cell and gene therapeutic applications. In: Mol Ther Nucleic Acids 2:e83.

Völker, I. et al. (2013): Intrahepatic application of suicide gene-armed measles virotherapeutics: a safety study in transgenic mice and rhesus macaques. In: Hum Gene Ther Clin Dev 24:11-22.

Wagner, E. (2004): Strategies to improve DNA polyplexes for in vivo gene transfer - will "artificial viruses" be the answer? In: Pharm Res 21:8-14.

Wagner, E. (2008): Converging paths of viral and non-viral vector engineering. In: Mol Ther 16:1-2.

Weber, C. et al. (2013): Foamy virus-adenovirus hybrid vectors for gene therapy of the arthritides. In: J Gene Med 15:155-167.

Weber, K. et al. (2008): A multi-color panel of novel lentiviral "gene ontology" (LeGO) vectors for functional gene analysis. In: Mol Ther 16:698-706.

Weber, K. et al. (2010): LeGO vectors equipped with novel drug selectable fluorescent proteins - new building blocks for cell marking and multi-gene analysis. In: Gene Ther 17:511-520. 
Weibel, S. et al. (2011): Viral-mediated oncolysis is the most critical factor in the late-phase of the tumor regression process upon vaccinia virus infection. In: BMC Cancer 11:68.

Weibel, S. et al. (2013): Treatment of malignant effusion by oncolytic virotherapy in an experimental subcutaneous xenograft model of lung cancer. In: J Transl Med 11:106.

Wilde, S. et al. (2012): Human antitumor CD8+ T cells producing Th1 polycytokines show superior antigen sensitivity and tumor recognition. J Immunol 189:598-605.

Williams, D. A. et al. (2010): Transatlantic consortium spotlights need for changes in gene therapy trials. In: Mol Ther 18:1892.

Wilson, J. M. (2005): Gendicine: the first commercial gene therapy product. In: Human Gene Ther $16: 1014$

Xie, Y. S. et al. (2010): Synergistic gastric cancer inhibition by chemogenetherapy with recombinant human adenovirus p53 and epirubicin: an in vitro and in vivo study. In: Oncol Rep 24:1613-1620.

Xue, S. A./Stauss, H. J. (2007): Enhancing immune responses for cancer therapy. In: Cell Mol Immunol 4:173-184.

Yang, Z. X., et al. (2010): Clinical study of recombinant adenovirus-p53 combined with fractionated stereotactic radiotherapy for hepatocellular carcinoma. In: J Cancer Res Clin Oncol 136:625-630.

$\mathrm{Yu}, \mathrm{M}$. et al. (2010): p53 gene therapy for pulmonary metastasis tumor from hepatocellular carcinoma. In: Anticancer Drugs 21:882-884.

Zhang, L. et al. (2013): Current progress on gene therapy for primary immunodeficiencies. In: Gene Ther 20(10):963-969.

Zhou, Q. et al. (2012): T-cell receptor gene transfer exclusively to human CD8(+) cells enhances tumor cell killing. In: Blood 120:4334-4342. 